\title{
A structured scientific solution to the Israeli-Palestinian conflict: the analytic hierarchy process approach
}

\author{
Thomas L. Saaty ${ }^{*}$, Luis G. Vargas and H. J. Zoffer
}

\author{
${ }^{*}$ Correspondence: \\ saaty@katz.pitt.edu \\ University of Pittsburgh, \\ Pittsburgh, PA, USA
}

\begin{abstract}
While the Israeli-Palestinian conflict has raged for decades, in all of its ramifications there has never been a totally structured or scientific approach to the conflict with all of its details. The Analytic Hierarchy Process (AHP) approaches the problem along these lines. There are a plethora of reasons why the traditional face to face negotiations have broken down over the years. This paper identifies a significant number of those impediments and indicates how the AHP can productively address them. A summary of the highlights of the AHP approach precedes how it has been applied to the Israeli-Palestinian conflict. To date, the participants, significant members of both communities, have derived and agreed upon a solution that includes all the major issues, except for the refugee problem. That problem is currently being worked on, but will take an extended period because of the unique factors involved. What has been provided is an agreed upon solution to virtually all of the issues impeding past negotiations, including borders, settlements, the status of Jerusalem, the Holy Places, security and expectations of each side.
\end{abstract}

\section{Background}

Five years ago we began preliminary work to organize the difficult issues, associated with the six decade old confrontation between Israel and the Palestinians. With the support of a number of private foundations, we were able, on several occasions, to gather together in Pittsburgh participant groups of equal size, consisting of people who were interested in and knowledgeable about this conflict. Over time these initial participants were replaced by citizens of Israel and of Palestinian residency. Finally, a group of prominent Israeli and Palestinian leaders were invited to complete the cycle. This latter group has worked together for several years and has developed trust and confidence in one another that facilitated their deliberations. These serious-minded and influential participants proceeded to pursue goals to provide decision makers with quantitatively based parameters with regard to the major issues involved in the conflict. The last two meetings were held in January and in April of 2014. A summary of how AHP can be used to resolve conflicts is shown in section two of this paper. Suffice it to say that the advantages which the AHP provides over face to face negotiations are critical intellectually and substantively.

These advantages include minimizing the emotional interplay between the parties, accurately measuring the impact of intangible factors not previously considered,

@ 2015 Saaty et al. This article is distributed under the terms of the Creative Commons Attribution 4.0 International License (http:// creativecommons.org/licenses/by/4.0/), which permits unrestricted use, distribution, and reproduction in any medium, provided you give appropriate credit to the original author(s) and the source, provide a link to the Creative Commons license, and indicate if changes were made. 
providing an opportunity to consider every possible issue involved, identifying all concessions that could be made by either party, no matter which party articulated them, providing an opportunity for tradeoffs between and among concessions, establishing values for each concession that create priorities expressing the importance, as accurately measured, of each factor involved, and using a hierarchical structure to establish the benefits, opportunities, costs and risks.

We began with testing how this retributive conflict (one in which both sides profess to desire a solution but were equally committed to inflicting pain on the other party) could be profitably addressed by the AHP, a mathematical theory concerned, among other factors, with the measurement of the crucial intangible criteria at the heart of this conflict. This paper can serve to illustrate how mathematics can help quantify the value of tradeoffs necessary to solve this impasse. Over the years, the AHP has been successfully applied in a wide variety of complex corporate and military decisions, involving resource allocation and prioritization of options, such as Poland's decision not to join the Euro zone, and in some extremely sensitive political situations, such as the conflicts in Northern Ireland and South Africa.

We are not the only ones who believe that the Israeli Palestinian interaction is one of the most serious problems facing the world community. According to the philanthropist Jeffrey Skoll in a television interview, the five problems he's convinced pose immediate danger to humanity are "climate change, water security, pandemics, nuclear proliferation and the Middle East conflict." (Skoll 2013).

\section{The analytic hierarchy process}

A particular challenge for dealing with controversies as intractable as the Israeli-Palestinian conflict is how to measure the intangible factors, which may even have more influence over the outcome than the tangible factors. AHP addresses this issue through the use of pairwise comparisons, because the importance of such factors changes from one problem to another. What is needed are relative priorities developed for each problem within the context of its own diversity of factors and their influences on the actors involved and the concessions that they exchange.

The Analytic Hierarchy modeling and measurement process (AHP) is a scientific approach used to determine the relative importance of a set of activities or criteria. The novel aspect and major distinction of this approach is that it structures any complex, multiperson, multi-criteria, and multi-period problem hierarchically. Using a method for scaling the weights of the elements in each level of the hierarchy with respect to an element (e.g., a criterion or property they share) of the next higher level, a matrix of pairwise comparisons of the activities can be constructed, where the entries indicate the strength with which one element dominates another with respect to a given criterion. This scaling formulation is translated into a largest eigenvalue problem, which results in a normalized and unique vector of priority weights for each level of the hierarchy (always with respect to the criteria in the next level), which in turn results in a single composite vector of weights for the entire hierarchy. This vector measures the relative priority of all entities at the lowest level that enables the accomplishment of the highest objective of the hierarchy. These relative priority weights can provide guidelines for the allocation of resources among the entities at the lower levels of the hierarchy. When hierarchies are designed to reflect likely environmental scenarios, corporate objectives, current and proposed product/market alternatives, and 
various marketing strategy options, the AHP can provide a framework and methodology for the determination of a number of key corporate and marketing decisions of the firm.

The AHP focuses on dominance matrices and their corresponding measurement- the ignored areas of research compared with the more popular proximity, profile, and conjoint measurement approaches. It goes beyond the probability kind of comparative judgment approach (which of two things is more likely to happen) by relaxing the assumption of normality on the parameters; e.g., equal variance and zero covariance and restriction of the type of comparisons. The Analytic Hierarchy develops the tradeoff in the course of structuring and analyzing a series of simple reciprocal pairwise comparison matrices. The AHP is based on three major components:

1. AHP begins by decomposing a complex problem into a hierarchy; each level consists of a few manageable elements and each element is, in turn, decomposed into another set of elements. The process continues down to the most specific elements of the problem, typically the specific courses of action considered, which are represented at the lowest level of the hierarchy. Structuring any decision problem hierarchically is an exercise in creative thinking and is an efficient way for dealing with complexity and identifying the major components of the problem. There is no single general hierarchical structure, and one of the major attributes of the AHP is the flexibility it allows to construct a hierarchy to fit the idiosyncratic needs of the decision makers.

2. A measurement methodology is used to establish priorities among the elements within each stratum of the hierarchy. This is accomplished by asking the participants to evaluate each set of elements in a pairwise fashion with respect to each of the elements in a higher stratum. This measurement methodology provides the framework for deriving numerical priorities for ranking the alternatives of action.

3. Work for data collection and analysis constitutes the heart of the AHP. Structurally, the hierarchy is broken down into a series of paired comparison matrices, and the participants are asked to evaluate the off-diagonal relationship in one half of each matrix. Reciprocals are placed in the transposed positions, because if A is judged to be five times bigger than B, then B needs to be $1 / 5$ as big as A.

Examples of how the AHP can be applied to a wide variety of problems are shown below.

\section{Comparing five areas}

Figure 1 shows five geometric areas to which we can apply the paired comparison process to test the validity of the procedure. The object is to compare them in pairs for area by eyeballing them to reproduce the overall relative weights or priorities. The absolute numbers for each pairwise comparison are shown in Table 1. Inverses are automatically entered in the transpose position. We can approximate the priorities from this matrix by normalizing each column and then taking the average of the corresponding entries in the columns. Table 1 gives the actual measurements in relative form on the right. An element on the left is compared with another at the top as to its dominance. If it is not larger than one, the top element is compared with it and the reciprocal value is used.

In making paired comparisons one assigns numbers to judgments about dominance. An element compared with itself with respect to a certain criterion is always equal to 1 . Therefore, the main diagonal entries of the pairwise comparison matrix are all 1 . The numbers 


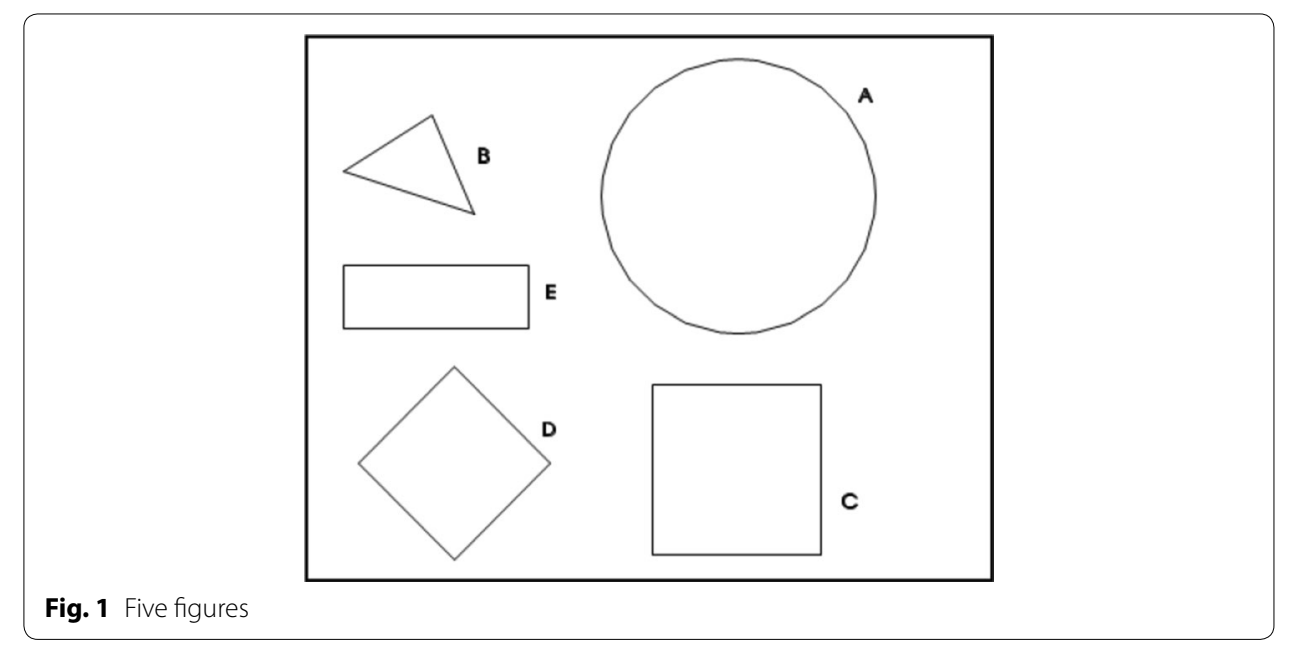

Table 1 Judgments, outcomes, and actual relative sizes of the five geometric shapes

\begin{tabular}{llllllll}
\hline Figure & Circle & Triangle & Square & Diamond & Rectangle & $\begin{array}{l}\text { Priorities } \\
\text { (Eigen-vector) }\end{array}$ & $\begin{array}{l}\text { Actual } \\
\text { relative size }\end{array}$ \\
\hline Circle & 1 & 9 & 2 & 3 & 5 & 0.462 & 0.471 \\
Triangle & $1 / 9$ & 1 & $1 / 5$ & $1 / 3$ & $1 / 2$ & 0.049 & 0.050 \\
Square & $1 / 2$ & 5 & 1 & $3 / 2$ & 3 & 0.245 & 0.234 \\
Diamond & $1 / 3$ & 3 & $2 / 3$ & 1 & $3 / 2$ & 0.151 & 0.149 \\
Rectangle & $1 / 5$ & 2 & $1 / 3$ & $2 / 3$ & 1 & 0.093 & 0.096 \\
\hline
\end{tabular}

The next-to-last column in Table 1 gives the priorities derived from judgment

$3,5,7$, and 9 correspond to the verbal judgments "moderately more dominant", "strongly more dominant", "very strongly more dominant", and "extremely more dominant", with 2 , 4,6 , and 8 between the previous values. Reciprocal values are automatically entered in the transpose position. We are permitted to interpolate values between the integers, if desired or use numbers from an actual ratio scale of measurement. The AHP uses the integers 1 to 9 as its Fundamental Scale of Absolute Numbers corresponding to the aforementioned verbal statements for the comparisons. This scale can be extended indefinitely by breaking things into clusters and using the largest element in one cluster as the smallest element in the next adjacent cluster, dividing all the priorities in the second cluster by this element's value and then multiplying all values in the second cluster by the priority of that element in the first cluster so that common element has the same value in the two clusters and so on. Thus one continues to use the same 1-9 values to compare elements in new clusters.

\section{Estimating US consumption of different drinks}

A more abstract form of comparisons would involve elements with tangible properties that one must think about but cannot be perceived through the senses. See the judgments in Table 2 for estimating the Relative Consumption of Drinks. An audience of about 30 people, using consensus to arrive at each judgment, provided judgments to estimate the dominance of the consumption of drinks in the United States (which drink is consumed more in the US and how much more than another drink?). The derived vector of relative consumption and the actual vector, obtained by normalizing the consumption given in official statistical data sources, are at the bottom of the table. 
Table 2 Relative consumption of drinks

Which Drink is Consumed More in the U.S.?

Drink

An Example of Estimation Using Judgments

in the U.S.

Coffee $\left[\begin{array}{ccccccc}1 & 9 & 5 & 2 & 1 & 1 & 1 / 2\end{array}\right.$

\begin{tabular}{l|ccccccc} 
Wine & 1 & 9 & 5 & 2 & 1 & 1 & $1 / 2$ \\
$1 / 9$ & 1 & $1 / 3$ & $1 / 9$ & $1 / 9$ & $1 / 9$ & $1 / 9$
\end{tabular}

\begin{tabular}{l|lllllll} 
Tea & $1 / 5$ & 2 & 1 & $1 / 3$ & $1 / 4$ & $1 / 3$ & $1 / 9$
\end{tabular}

\begin{tabular}{l|lllllll} 
Beer & $1 / 2$ & 9 & 3 & 1 & $1 / 2$ & 1 & $1 / 3$
\end{tabular}

\begin{tabular}{l|lllllll} 
Sodas & 1 & 9 & 4 & 2 & 1 & 2 & $1 / 2$
\end{tabular}

$\begin{array}{llllcccc}\text { Milk } & 1 & 9 & 3 & 1 & 1 / 2 & 1 & 1 / 3 \\ \text { Water } & 2 & 9 & 9 & 3 & 2 & 3 & 1\end{array}$

Water 1

Coffee Wine Tea Beer Sodas Milk Water

$\begin{array}{lllllll}.177 & .019 & .042 & .116 & .190 & .129 & .327\end{array}$

The actual consumption (from statistical sources) is:

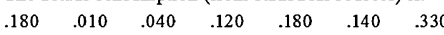

Note that while in the first example, Table 1, the eye perceives different size areas, in the second example, Table 2, the mind, through wide experience and education, has a feeling for how much more frequently one drink is consumed than the other is consumed, in a pairwise comparison. Feelings are usually distinguished qualitatively and associated with numerical values. It is fortunate, in this example, that people tend to consume nearly the same amount of liquid, about a glassful, of whatever kind of drink is being consumed. Estimating the quantity of consumption is different than estimating frequency of consumption.

\section{Buying the Best Car}

How do we choose the best car from among three alternatives by considering different importance priorities for the four criteria, some intangible and some tangible: prestige, price, miles per gallon and comfort? We use the hierarchy in Fig. 2 to represent this decision.

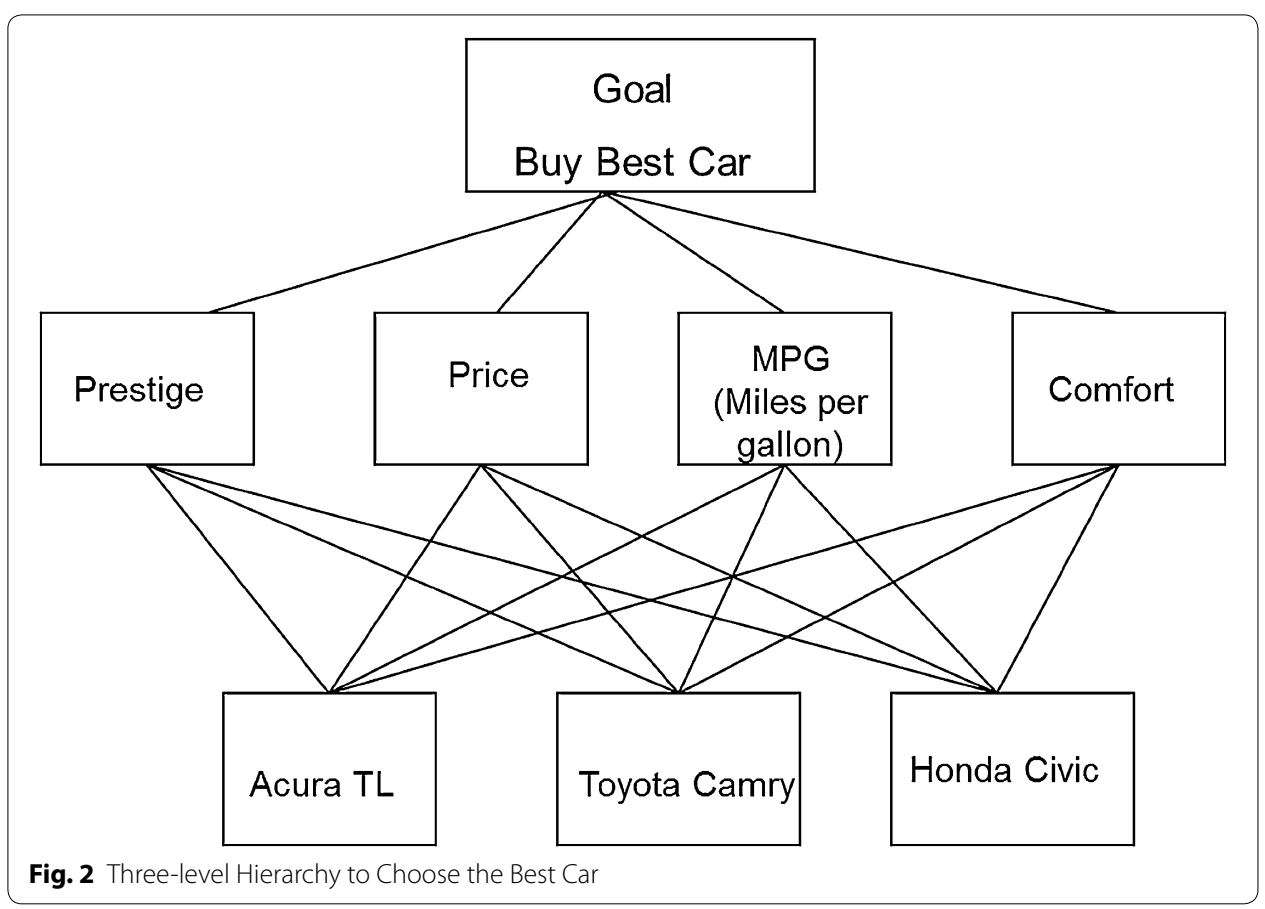


The pairwise comparisons of the criteria are given in Table 3. Criteria must always be compared to derive their priorities. We then compare the alternatives with respect to the criteria in Table $4 \mathrm{a}-\mathrm{d}$. Table 5 gives the synthesis of the priorities of the alternatives shown in the next-to-last columns of Table $4 a-d$, multiplied by the priorities of the criteria given in the last column of Table 3 . The process of weighting, adding and normalizing priorities to one is called the distributive mode of synthesis. By contrast if one divides by the largest priority among the synthesized values, the result is called the ideal mode of synthesis. For more about synthesis modes see (Saaty 2005).

Psychologists have noted that there are two ways to make comparisons of alternatives. One is to compare them by considering each pair, as we have done above, and the other is to compare each alternative with an ideal one has in mind. Because, in the case of cars,

Table 3 Pairwise comparisons of the criteria as to their importance in choosing a best car

\begin{tabular}{llcccc}
\hline Goal & Prestige & Price & MPG & Comfort & Priorities \\
\hline Prestige & 1 & $1 / 4$ & $1 / 3$ & $1 / 2$ & 0.099 \\
Price & 4 & 1 & 3 & $3 / 2$ & 0.425 \\
MPG & 3 & $1 / 3$ & 1 & $1 / 3$ & 0.169 \\
Comfort & 2 & $2 / 3$ & 3 & 1 & 0.308
\end{tabular}

Table 4 Comparisons of the alternatives with respect to the criteria

\begin{tabular}{|c|c|c|c|c|c|}
\hline Prestige & Acura TL & Toyota Camry & Honda Civic & Priority Distributive & Priority Ideal \\
\hline \multicolumn{6}{|c|}{ (a) Comparison of cars with respect to prestige } \\
\hline Acura TL & 1 & 8 & 4 & 0.707 & 1 \\
\hline Toyota Camry & $1 / 8$ & 1 & $1 / 4$ & 0.07 & 0.099 \\
\hline Honda Civic & $1 / 4$ & 4 & 1 & 0.223 & 0.315 \\
\hline \multicolumn{6}{|c|}{ (b) Comparison of cars with respect to price } \\
\hline Acura TL & 1 & $1 / 4$ & $1 / 9$ & 0.063 & 0.085 \\
\hline Toyota Camry & 4 & 1 & $1 / 5$ & 0.194 & 0.261 \\
\hline Honda Civic & 9 & 5 & 1 & 0.743 & 1 \\
\hline \multicolumn{6}{|c|}{ (c) Comparison of cars with respect to MPG } \\
\hline Acura TL & 1 & $2 / 3$ & $1 / 3$ & 0.182 & 0.333 \\
\hline Toyota Camry & $11 / 2$ & 1 & $1 / 2$ & 0.273 & 0.5 \\
\hline Honda Civic & 3 & 2 & 1 & 0.545 & 1 \\
\hline \multicolumn{6}{|c|}{ (d) Comparison of cars with respect to comfort } \\
\hline Acura TL & 1 & 4 & 7 & 0.705 & 1 \\
\hline Toyota Camry & $1 / 4$ & 1 & 3 & 0.211 & 0.299 \\
\hline Honda Civic & $1 / 7$ & $1 / 3$ & 1 & 0.084 & 0.119 \\
\hline
\end{tabular}

Table 5 Synthesis of the priorities of the alternatives

\begin{tabular}{llllll}
\hline Priorities & Prestige $\mathbf{0 . 0 9 9}$ & Price $\mathbf{0 . 4 2 5}$ & MPG $\mathbf{0 . 1 6 9}$ & Comfort $\mathbf{0 . 3 0 8}$ & $\begin{array}{l}\text { Synthesis of } \\
\text { Overall Priorities }\end{array}$ \\
\hline Acura TL & 0.707 & 0.063 & 0.182 & 0.705 & 0.342 \\
Toyota Camry & 0.070 & 0.194 & 0.273 & 0.211 & 0.204 \\
Honda Civic & 0.223 & 0.743 & 0.545 & 0.084 & 0.454 \\
\hline
\end{tabular}

The Honda Civic is the best car to buy because its overall priority is the largest 
we only know about the three cars we are considering, we make the best of them under each criterion the ideal for that criterion. To do that we divide the priorities under each criterion by the largest among them and that one becomes the ideal. This is shown in the last column of Table $4 \mathrm{a}-\mathrm{d}$. Using those values we have Table 6 to obtain the synthesis of the alternatives.

Note that the overall priorities are different but the ranks and the normalized priorities are the same in Tables 5 and 6, but they need not be. Frequently people prefer to use the answer in Table 6, because that way if more cars are added each is compared only with the ideal for that criterion and the rank of the three initial alternatives stays the same.

Actually, one would not interpret tangibles to make a decision for another person and often would use the actual measurements for those tangibles as indicators for their relative worth or importance. Thus, if instead of using judgments for the price, we use the ratio of the actual prices as shown in Table 7 (in fact, we use the inverses of these ratios because lower prices should have higher priorities) and then compute the priorities, we would obtain the same answer as simply normalizing the prices. In using direct data one must be careful to invert the priorities obtained if higher numbers mean less desirable.

With the ratio of the actual prices being used for the vector of priorities, Table 8 gives the overall priorities of the alternatives in the ideal mode.

In this case the Acura is slightly better than the Honda, but not by very much. As to be expected, the priorities in Table 8 are different from those in Table 6, obtained from judgments.

Table 6 Synthesis of the priorities of the alternatives using ideals to obtain the overall priorities

\begin{tabular}{lllllll}
\hline Priorities & Prestige $\mathbf{0 . 0 9 9}$ & Price $\mathbf{0 . 4 2 5}$ & MPG 0.169 & Comfort 0.308 & Overall priorities & Normalized \\
\hline Acura TL & 1.000 & 0.085 & 0.333 & 1.000 & 0.499 & 0.342 \\
Toyota Camry & 0.099 & 0.261 & 0.500 & 0.299 & 0.297 & 0.204 \\
Honda Civic & 0.315 & 1.000 & 1.000 & 0.119 & 0.661 & 0.454 \\
\hline
\end{tabular}

Again, the Honda Civic is the best

Table 7 Priorities of cars with respect to price using actual dollar values

\begin{tabular}{llllll}
\hline $\begin{array}{l}\text { Price in } \\
\text { Dollars }\end{array}$ & $\begin{array}{l}\text { Average } \\
\text { Prices }\end{array}$ & $\begin{array}{l}\text { Average Prices Used } \\
\text { as Priorities }\end{array}$ & $\begin{array}{l}\text { Invert } \\
\text { Priorities }\end{array}$ & $\begin{array}{l}\text { Final Priorities } \\
\text { (normalized) }\end{array}$ & $\begin{array}{l}\text { Ideal } \\
\text { Priorities }\end{array}$ \\
\hline Acura TL & 32,500 & 0.425 & $1 / 0.425$ & 0.247 & 0.554 \\
Toyota Camry & 26,000 & 0.340 & $1 / 0.340$ & 0.308 & 0.692 \\
Honda Civic & 18,000 & 0.235 & $1 / 0.235$ & 0.445 & 1.000 \\
Sum & 76,500 & 1 & 0.00012479 & 1 & \\
\hline
\end{tabular}

Table 8 Ideal synthesis to obtain the priorities of the cars

\begin{tabular}{lllllll}
\hline Priorities & Prestige $\mathbf{0 . 0 9 9}$ & Price $\mathbf{0 . 4 2 5}$ & MPG $\mathbf{0 . 1 6 9}$ & Comfort 0.308 & Overall Priorities & $\begin{array}{l}\text { Normalized } \\
\text { to One }\end{array}$ \\
\hline Acura TL & 1.000 & 0.554 & 0.333 & 1.000 & 0.698 & 0.379 \\
Toyota Camry & 0.099 & 0.692 & 0.500 & 0.299 & 0.480 & 0.261 \\
Honda Civic & 0.315 & 1.000 & 1.000 & 0.119 & 0.661 & 0.359 \\
\hline
\end{tabular}


We note that in making comparisons, the value of any element depends on the value of what it is compared with. It is not like assigning it a number from a scale of measurement with an arbitrary unit. This led to a criticism about rank reversal when new alternatives are added or old ones deleted by those who, in single but nor multiple criteria rankings, were only used to assigning elements one at a time numbers from a scale. In multicriteria decisions, for example, criteria need to always be compared because one cannot meaningfully assign importance to them, even if some people try doing it, and scales are then developed for each criterion separately. The answer to rank preservation or reversal does not lie in a mathematical theorem that says that rank must always be preserved. There are numerous examples that show that rank reversals can and should occur in practice (Saaty 2005).

To preserve rank, the ratings mode was developed by constructing through pairwise comparisons a rating scale for each criterion. These rating scales opened the door for using numerical data in normalized (by dividing each value by the sum of all the values) form, and also using mathematical functions as desired. Alternatives are then rated independently, one at a time, by selecting the appropriate rating for it on each criterion. By preevaluating ranges of data through expert judgment, it makes it possible to automate the process of evaluating data. Thus, one uses comparisons or ratings, depending on the circumstances. When the criteria are changeable, as in selecting the best CEO for a company, one uses comparisons and its corresponding method of synthesis, called the distributive mode. When the criteria are standardized, as in the admission of students to a university, evaluating projects or military officers, one uses ratings with its ideal mode, even when the ideal may change because of adding new alternatives never previously encountered or conceived. Note: This is the method we use below to derive the priorities of the concessions with respect to benefits, costs, perceived benefits and costs in all the tables that follow.

\section{Retributive conflicts and the AHP}

There are two types of conflict resolution. We call the first kind constructive. It is what is conventionally treated in the so-called rational approach to conflict resolution. Each party identifies its demands, and it is assumed that a way can be found to satisfy both parties' demands fairly. Fairly here means that each party forms a ratio of its benefits to those of the opponent and attempts to satisfy its own needs, at least as much as its perceived evaluation of the opponent's benefits, because the utilities or values may be interpreted differently by the two sides. The tug of war by each side can end up in equalizing the ratio to unity. That is why it is inadvisable for either party to give up too early.

In this case, negotiations begin with each party setting down what it expects to get. The negotiations may either result in getting that much, or changing the outcome so that both sides receive more, or often, less than their expectations because there is not enough to go around. The parties begin by offering some concessions from a larger set of concessions, which they maintain secretly. An offer is evaluated in terms of the benefits of the counter-offer received and may be withdrawn, if not reciprocated adequately.

The second kind of conflict is retributive with one or both parties harboring ill will towards each other. The idea is particularly relevant in long drawn-out conflicts, which in the end fester and create almost ineradicable resentments. Here a party may be willing to give up much of its demands, if misfortune can be brought to its opponent through some means, including justice as dispensed by the court system. Should the enemy die, 
they may forgive and forget, or sometimes they may be resentful because they have not extracted their pound of flesh.

Thus, in negotiations, each party not only calculates the incremental benefits it gets, but also the costs to its opponent. The more of either, the greater is the gain. Gain is the product of the benefits to the party and the costs (whose aim may also be long-run benefits) to the opponent. Each side must calculate what it estimates to be the opponent's gain as a product of benefits to the opponent and costs to itself and make sure that the ratio of its gain to the opponent's gain, which it considers as a loss, is greater than unity or not less than what the opponent is perceived to get. Thus, each party is concerned with maximizing its gains via its benefits and the costs to the opponent, and also by negotiating to increase this gain and decrease its loss (which is a gain to the opponent). When several concessions are considered simultaneously, sums of the products of benefits and costs must be taken. We have the following ratios for the two parties A and B:

(as perceived by A)

$$
A^{\prime} \text { 's ratio } \frac{\text { gain to } \mathrm{A}}{A^{\prime} \text { s perception of gain to } \mathrm{B}}=\frac{\sum \mathrm{A} \text { 's benefits } \times \text { B's costs }}{\sum \text { B's benefits } \times \text { A's costs }}=\frac{\text { gain to } \mathrm{A}}{\text { loss to } \mathrm{A}}
$$

where $\sum$ is the sum taken over all concessions by $\mathrm{B}$ in the numerator and by $\mathrm{A}$ in the denominator. A's perceived ratio for $\mathrm{B}$ is the reciprocal of the above.

(as perceived by B)

$$
B \text { 's ratio } \frac{\text { gain to } B}{B \text { 's perception of gain to } A}=\frac{\sum \text { B's benefits } \times \text { A's costs }}{\sum \text { A's benefits } \times \text { B's costs }}=\frac{\text { gain to } B}{\text { loss to } B}
$$

where $\Sigma$ is the sum taken over all concessions by A in the numerator and by $\mathrm{B}$ in the denominator. A's perceived ratio for A is the reciprocal of the above. If both A and B's perceive benefits and costs in the same way, these ratios would be reciprocals of each other. This almost never happens, however.

Obviously, each party would like its ratio to be as high as possible. If A`s ratio for some package is less than 1, then A will perceive B`s ratio as being greater than 1 and will feel that it has not been treated fairly. The aim must be to find single concessions and groups of concessions where each party perceives its own ratio to be greater than 1 . This requires skilled mediation.

As just explained, each party calculates its gain as the product of its benefits and its perceived value of the costs to the opponent and its loss as the product of its costs and its perceived value of the benefits to the opponent. Thus, in a conflict resolution scenario, wherein each party has a set of concessions to make, party A, for example, calculates the benefits it will accrue from B's concessions to A, and its perception of the costs to $\mathrm{B}$ for these concessions.

Thus, there will ordinarily be four such calculations for each party and many more for a mediator, for example, who would use the judgments the parties give him and would compare them with his own perceptions; the mediator would then attempt to alter their perceptions or convince them that certain concessions are more to their advantage and advise them of the order in which such concessions should be made. 
If each of the ratios is perceived by the corresponding party to be less than unity, the problem is to alter these perceptions, so that both parties think that they are equally treated. By looking at their own ratio and the opponent's ratio as perceived by them, which is the reciprocal of their ratio, the parties will tend to argue as follows: "Look what I am giving up. He gets high benefits and the costs to me are very high. He should be happy. On the other hand, look at what he is offering me. My benefits are low and the costs to him are very low. It is not a fair trade. He is not hurting enough in what he is offering me."

Note that constructive conflict resolution is a special case of retributive conflict resolution whereby the costs to the opponent are assigned a unit value. Each party assumes that the opponent is paying the full cost and concentrates on maximizing its own benefits. He cannot assign any additional costs to the opponent.

The chief purpose of AHP is to provide decision makers with objective, numerical parameters regarding specific core issues. From such a valuation model, decision makers have access to a rationally based model/tool for addressing and resolving specific, complex issues.

The primary benefit of the AHP as a tool for Middle East peace negotiators, whether used internally or together between the parties, is to reduce uncertainties-between and among the parties-on the relative value of core issues as negotiators address the "trade-off/exchange" component of negotiations. The information produced by this tool enhances rationally-based decision-making, helps reduce emotion in negotiations, and assesses more accurately the relative value that each group attaches to a particular issue.

The trade-off model is predicated upon development and application of a process that reflects both in-depth understanding of values attached by the respective parties (or sub-parties) to an issue, and the importance of that issue in relation to other issues, of lesser, similar, or greater value. Of equal importance is determining the value the other side attaches to that issue and the value both sides attach within the context of a tradeoff or trade-offs.

The process requires assigning numerical values that measure the respective importance of each issue for the parties involved; it is that assessment/assignment that enables rationally based decision-making in the context of potential trade-offs. AHP focuses on articulation and application of self-interest in a paradigm emphasizing trade-offs, whereby both sides seek to "expand the pie" - and avoid zero-sum calculations that emphasize maximization of benefits for one side, to the detriment of the other side.

The list of eight basic ideas behind the trade-offs is as follows:

1. Each party identifies a set of concessions (trade-offs). For example Tables 9 and 10 reflect these basic ideas in the case of the Israeli-Palestinian controversy.

2. Each trade-off that a party gives away yields for that party a set of costs (not necessarily monetary) and a perceived set of benefits for the party receiving it (Table 11).

3. Each trade-off that a party receives generates a set of benefits and a perceived set of losses for the party giving it away (Table 12).

4. The benefits, costs, perceived benefits and perceived costs are prioritized, using the AHP. (see the Priorities column in Tables 11 and 12).

5. The trade-offs are evaluated according to the benefits, costs, perceived benefits, and perceived costs (Table 13). 
Table 9 Possible Israeli concessions

\begin{tabular}{ll}
\hline Israelis' concessions & Description \\
\hline 1 & Abandon the Idea of a Jewish State \\
2 & Accept Palestinian full control of the borders of the Palestinian State and its outlets \\
3 & Accept the historical responsibility for the Palestinian refugee problem \\
4 & Accept the Palestinian refugee rights to return \\
5 & Accept to abide by the status quo in the holy places in Jerusalem \\
6 & Accept to abolish the law of return \\
7 & Accept to respect the integrity of the West Bank and Gaza by allowing free and safe pas- \\
8 & sage between the two areas \\
9 & Accept East Jerusalem as the capital of the Palestinian State \\
10 & Accept Two-State solution on the borders of the 4th of June 1967 \\
11 & Allow all parties to have equal access to and control of religious sites and holy places \\
12 & Allow the sharing of all natural resources between Palestinians and Israelis \\
13 & Comply with all applicable UN Resolutions \\
14 & Evacuate settlers of Jewish settlements on land claimed by the Palestinians with or \\
15 & without compensation \\
16 & Release all political prisoners including those who are Israeli citizens \\
17 & Share Jerusalem as two capitals of two states \\
& Solve the Palestinian refugee problem in a just and agreed upon manner \\
& Stop incitement by the religious and national education and religious leaders in Israel \\
& against Muslims and Arabs
\end{tabular}

Table 10 Possible Palestinian concessions

\begin{tabular}{|c|c|}
\hline Palestinians' concessions & Description \\
\hline 1 & Accept mutually agreed upon land swap \\
\hline 2 & Accept settlers under Palestinian sovereignty as residents \\
\hline 3 & $\begin{array}{l}\text { Accept the temporary presence of a multinational military monitoring system in } \\
\text { Jordan Valley }\end{array}$ \\
\hline 4 & Accept a Two-State solution \\
\hline 5 & Accept a Two-State solution which includes a non-contiguous state \\
\hline 6 & Acknowledge Israel's existence as a Jewish State \\
\hline 7 & Acknowledge Israel's existence as an independent state \\
\hline 8 & Agree to compromise to the demand of the right of return \\
\hline 9 & Agreeing with Palestinian demilitarized state \\
\hline 10 & Preserve the status quo in the Holy places of Jerusalem \\
\hline 11 & Allow Israel to use Palestinian airspace \\
\hline 12 & Declare against Iranian nuclear development \\
\hline 13 & Denounce and reign in violence \\
\hline 14 & $\begin{array}{l}\text { Denounce Iranian pursuit of nuclear arms and support Israelis effort to remove the } \\
\text { threat }\end{array}$ \\
\hline 15 & $\begin{array}{l}\text { Lobby Arab states to allow both Israelis and Palestinians to have the right to return } \\
\text { to their land of origin }\end{array}$ \\
\hline 16 & Make compromises on the status of Jerusalem \\
\hline 17 & $\begin{array}{l}\text { Palestinians must guarantee that any agreement reached with Israel will be } \\
\text { accepted and supported by the majority of the Palestinian people, both in Gaza } \\
\text { and the West Bank }\end{array}$ \\
\hline 18 & Refrain and work against any anti-Israel sentiments in Palestinian schools \\
\hline 19 & Seek assistance for a legitimate settlement of refugees \\
\hline 20 & Sharing of natural resources \\
\hline 21 & Work cooperatively and in active engagement w/Israel \\
\hline
\end{tabular}


Table 11 Israeli and Palestinian costs and perceived benefits

\begin{tabular}{|c|c|}
\hline & Priorities \\
\hline \multicolumn{2}{|l|}{ Israeli costs from its concessions } \\
\hline Integrity and unity of Israeli society post-agreement & 0.0659 \\
\hline Security & 0.1831 \\
\hline Strengthening the alliance with the United States & 0.0457 \\
\hline Make Israel more attractive to Jewish diaspora and Israelis citizens & 0.0322 \\
\hline End of claims and end of conflict & 0.2093 \\
\hline Legitimization of the State of Israel & 0.0778 \\
\hline Stop being occupiers & 0.0477 \\
\hline Peace, economy and stability in region & 0.086 \\
\hline Maintain the Jewish majority of Israel alongside with the Arab minority & 0.2249 \\
\hline Weakening the radical forces in the Middle East headed by Iran & 0.0274 \\
\hline \multicolumn{2}{|l|}{ Israeli perception of Palestinian benefits from Israeli concessions } \\
\hline Freedom, dignity and feeling of equality & 0.1449 \\
\hline Independent state & 0.2145 \\
\hline Evacuation of the settlers in the settlements & 0.0661 \\
\hline International recognition and permanent borders & 0.0368 \\
\hline Maximization of the area (land) & 0.0816 \\
\hline Economic stability and prosperity & 0.0219 \\
\hline East Jerusalem as the capital of Palestine & 0.1361 \\
\hline Solve the Refugee problem & 0.2128 \\
\hline Control of the Muslim holy places & 0.0853 \\
\hline \multicolumn{2}{|l|}{ Palestinian costs from its concessions } \\
\hline Conflict between Palestinian diaspora and the internal leadership & 0.0948 \\
\hline Giving up the claim over historic Palestine occupied in 1948 and known later as the State of Israel & 0.2055 \\
\hline Partial loss/depletion of natural resources by sharing them with Israel & 0.1257 \\
\hline Loss of military capability to defend the State of Palestine & 0.0575 \\
\hline Territorial loss as a result of unfair land swap & 0.2173 \\
\hline Accommodation and rehabilitation of Palestinian refugees not allowed to return to Israel & 0.1192 \\
\hline Restrictions on national sovereignty by accepting demilitarization and multinational monitoring & 0.1013 \\
\hline Loss of property rights & 0.0395 \\
\hline Dislocation and fragmentation of Palestinian social fabric & 0.0392 \\
\hline \multicolumn{2}{|l|}{ Palestinian perception of Israeli benefits from Palestinian concessions } \\
\hline Gaining legitimacy of the Palestinian and Arab and Muslim world & 0.1111 \\
\hline Integration in the Middle East with normal relations with its neighbors and Arab World & 0.0658 \\
\hline End of claims by the Palestinians & 0.2556 \\
\hline Obtaining security by acceptance and recognition of the Palestinian and Arab and Muslim world & 0.108 \\
\hline Sharing the Palestinians with their own natural resources & 0.0215 \\
\hline Obtaining territorial gains & 0.1184 \\
\hline $\begin{array}{l}\text { Economic relations and new markets including tourism with neighboring Arab and Islamic coun- } \\
\text { tries }\end{array}$ & 0.0999 \\
\hline Reduction of military expenditures enabling national development & 0.0239 \\
\hline Regional cooperation against external threats & 0.0333 \\
\hline $\begin{array}{l}\text { Acknowledgement of Israeli control over the Wailing Wall and the Jewish Quarter in the Old City of } \\
\text { Jerusalem }\end{array}$ & 0.1626 \\
\hline
\end{tabular}

6. The trade-offs of the parties are paired to decide which pairs are acceptable. Acceptable means that both parties benefit from the trade-off and that they receive more than they lose from the trade-off they give away. Acceptability of a pair of trade-offs 
Table 12 Israeli and Palestinian benefits and perceived costs

\begin{tabular}{|c|c|}
\hline & Priorities \\
\hline \multicolumn{2}{|l|}{ Israeli benefits from Palestinian concessions } \\
\hline Integrity and unity of Israeli society post agreement & 0.0753 \\
\hline Security & 0.1636 \\
\hline Strengthening the alliance with the United States & 0.0477 \\
\hline Make Israel more attractive to Jewish diaspora and Israelis citizens & 0.0397 \\
\hline End of claims & 0.2216 \\
\hline Legitimization of the State of Israel & 0.0654 \\
\hline Stop being occupiers & 0.0529 \\
\hline Peace, prosperity and stability in region & 0.0959 \\
\hline Maintain the Jewish majority of Israel alongside with the Arab minority & 0.1899 \\
\hline Weakening the radical forces in the Middle East headed by Iran & 0.0479 \\
\hline \multicolumn{2}{|l|}{ Israeli perception of Palestinian costs from Palestinian concessions } \\
\hline Giving up on the Idea of a Greater Palestine & 0.088 \\
\hline Remainder of part of the Settlement Community & 0.0964 \\
\hline Loss of 'victim'status & 0.0288 \\
\hline Loss of land (67 Border)/swap & 0.15 \\
\hline Loss of International financial support & 0.0252 \\
\hline Partial control of East Jerusalem as the capital of Palestine & 0.1735 \\
\hline Partial solution refuge problem & 0.3101 \\
\hline Partial control of the Muslim holy places & 0.128 \\
\hline \multicolumn{2}{|l|}{ Palestinian benefits from Israeli concessions } \\
\hline Permanent borders & 0.2095 \\
\hline Sovereign Palestinian State & 0.2054 \\
\hline Share of water and other resources & 0.0181 \\
\hline Resolution of the refugee problem & 0.0654 \\
\hline Shared control of Jerusalem and holy places & 0.0613 \\
\hline International guarantees and assurances to protect Palestine State security and integrity & 0.0403 \\
\hline Evacuation of the Israeli settlements & 0.0415 \\
\hline Having full control over air space, maritime, borders and outlets & 0.1086 \\
\hline Release of political prisoners including those who are Israeli citizens & 0.0186 \\
\hline Respect the integrity of West Bank and Gaza & 0.0571 \\
\hline Stop incitement and raging hatred & 0.0087 \\
\hline East Jerusalem as the capital of the State of Palestine & 0.1654 \\
\hline \multicolumn{2}{|l|}{ Palestinian perception of Israeli costs from Israeli concessions } \\
\hline Changing of Zionist narrative & 0.4541 \\
\hline Property restitution and compensation & 0.0689 \\
\hline Settlements evacuation & 0.2723 \\
\hline Rehabilitating evacuated settlers from the Palestinian territories & 0.2047 \\
\hline
\end{tabular}

is implemented using a gain-loss ratio. Gain-loss ratios are not symmetric for the parties.

7. Acceptable pairs of trade-offs are identified with the additional condition that the gain-loss ratio of a pair of concessions is as close as possible for the parties (i.e., within a small percentage of each other). Total equality in the tradeoffs is highly unlikely because of computational imprecision.

8. If the gain-loss ratios for all the acceptable pairs of trade-offs are as close as possible, the totality of the pairs of trade-offs should be as close as possible, and the agreement should be balanced (Fig. 3). 
Table 13 Evaluation of Trade-offs

\begin{tabular}{|c|c|c|c|c|c|c|}
\hline Concessions & $\begin{array}{l}\text { Israelis' Costs } \\
\text { (2) }\end{array}$ & $\begin{array}{l}\text { Israelis' } \\
\text { Perception } \\
\text { of Palestinians' } \\
\text { Benefits (3) }\end{array}$ & $\begin{array}{l}\text { Israelis' } \\
\text { Total Loss } \\
(2)^{*}(3)^{*} 1000\end{array}$ & $\begin{array}{l}\text { Palestinians' } \\
\text { Benefits (5) }\end{array}$ & $\begin{array}{l}\text { Palestinians' } \\
\text { Perception } \\
\text { of Israelis Costs } \\
\text { (6) }\end{array}$ & $\begin{array}{l}\text { Palestinians' } \\
\text { Total Gain } \\
(5)^{*}(6)^{*} 1000\end{array}$ \\
\hline \multicolumn{7}{|l|}{ Israelis } \\
\hline 1 & 1 & 1 & 1000 & 0.8875 & 0.9683 & 859.43 \\
\hline 2 & 0.6445 & 0.7637 & 492.18 & 0.9892 & 0.9717 & 961.20 \\
\hline 3 & 0.9051 & 0.2705 & 244.88 & 0.9565 & 0.7835 & 749.44 \\
\hline 4 & 0.9470 & 0.8253 & 781.53 & 0.8884 & 0.9515 & 845.25 \\
\hline 5 & 0.1961 & 0.5405 & 106.01 & 0.8008 & 0.7583 & 607.29 \\
\hline 6 & 0.8824 & 0.4280 & 377.70 & 0.5455 & 0.7410 & 404.22 \\
\hline 7 & 0.1984 & 0.5149 & 102.15 & 0.9838 & 0.9054 & 890.73 \\
\hline 8 & 0.8299 & 0.8068 & 669.54 & 1 & 0.9692 & 969.17 \\
\hline 9 & 0.0545 & 0.8205 & 44.75 & 0.9829 & 0.9080 & 892.42 \\
\hline 10 & 0.1006 & 0.5323 & 53.55 & 0.8053 & 0.5459 & 439.65 \\
\hline 11 & 0.1120 & 0.2853 & 31.96 & 0.6691 & 0.5260 & 351.93 \\
\hline 12 & 0.8596 & 0.9571 & 822.76 & 0.9847 & 0.9075 & 893.59 \\
\hline 13 & 0.3593 & 0.8915 & 320.31 & 0.9310 & 1 & 930.98 \\
\hline 14 & 0.5178 & 0.4781 & 247.56 & 0.7528 & 0.6508 & 489.95 \\
\hline 15 & 0.1633 & 0.6027 & 98.42 & 0.8472 & 0.7334 & 621.31 \\
\hline 16 & 0.1806 & 0.7329 & 132.34 & 0.8884 & 0.9174 & 815.03 \\
\hline 17 & 0.0741 & 0.1110 & 8.23 & 0.4134 & 0.4991 & 206.29 \\
\hline Concessions & $\begin{array}{l}\text { Palestinians' } \\
\text { Costs (2) }\end{array}$ & $\begin{array}{l}\text { Palestinians' } \\
\text { Perception } \\
\text { of Israelis' } \\
\text { Benefits (3) }\end{array}$ & $\begin{array}{l}\text { Palestinians' } \\
\text { Total Loss } \\
(2)^{*}(3)^{*} 1000\end{array}$ & $\begin{array}{l}\text { Israelis' Ben- } \\
\text { efits (5) }\end{array}$ & $\begin{array}{l}\text { Israelis' Percep- } \\
\text { tion of Pales- } \\
\text { tinians' Costs } \\
\text { (6) }\end{array}$ & $\begin{array}{l}\text { Israelis' } \\
\text { Total Gain } \\
(5)^{*}(6)^{*} 1000\end{array}$ \\
\hline \multicolumn{7}{|l|}{ Palestinians } \\
\hline 1 & 0.9349 & 0.2000 & 186.95 & 0.9233 & 0.6353 & 586.55 \\
\hline 2 & 0.8877 & 0.2000 & 177.51 & 0.2333 & 0.4743 & 110.66 \\
\hline 3 & 0.8101 & 0.2000 & 161.99 & 0.7033 & 0.1106 & 77.80 \\
\hline 4 & 0.8518 & 0.8947 & 762.13 & 0.9944 & 0.1660 & 165.08 \\
\hline 5 & 0.8438 & 0.2000 & 168.74 & 0.7543 & 0.3011 & 227.15 \\
\hline 6 & 0.9035 & 0.9345 & 844.30 & 0.8741 & 1 & 874.13 \\
\hline 7 & 0.8635 & 0.2000 & 172.67 & 0.8055 & 0.6196 & 499.09 \\
\hline 8 & 0.9298 & 0.9572 & 889.98 & 1 & 0.8557 & 855.72 \\
\hline 9 & 0.8718 & 0.2000 & 174.33 & 0.5968 & 0.1353 & 80.74 \\
\hline 10 & 0.7691 & 0.2331 & 179.27 & 0.7031 & 0.3355 & 235.85 \\
\hline 11 & 0.8957 & 0.2000 & 179.12 & 0.6592 & 0.1096 & 72.28 \\
\hline 12 & 0.5522 & 0.2000 & 110.42 & 0.3968 & 0.0348 & 13.81 \\
\hline 13 & 0.6878 & 0.2000 & 137.54 & 0.6153 & 0.1119 & 68.87 \\
\hline 14 & 0.5098 & 0.2000 & 101.95 & 0.4967 & 0.0443 & 22.00 \\
\hline 15 & 0.8119 & 0.2000 & 162.35 & 0.2009 & 0.3663 & 73.61 \\
\hline 16 & 1 & 1 & 1000.00 & 0.9251 & 0.6221 & 575.49 \\
\hline 17 & 0.5796 & 0.2000 & 115.90 & 0.8541 & 0.5253 & 448.69 \\
\hline 18 & 0.7352 & 0.2000 & 147.01 & 0.7583 & 0.1871 & 141.88 \\
\hline 19 & 0.8621 & 0.3908 & 336.96 & 0.9572 & 0.8724 & 835.03 \\
\hline 20 & 0.8158 & 0.2000 & 163.14 & 0.4069 & 0.0544 & 22.14 \\
\hline 21 & 0.2000 & 0.2000 & 39.99 & 0.7613 & 0.1858 & 141.44 \\
\hline
\end{tabular}




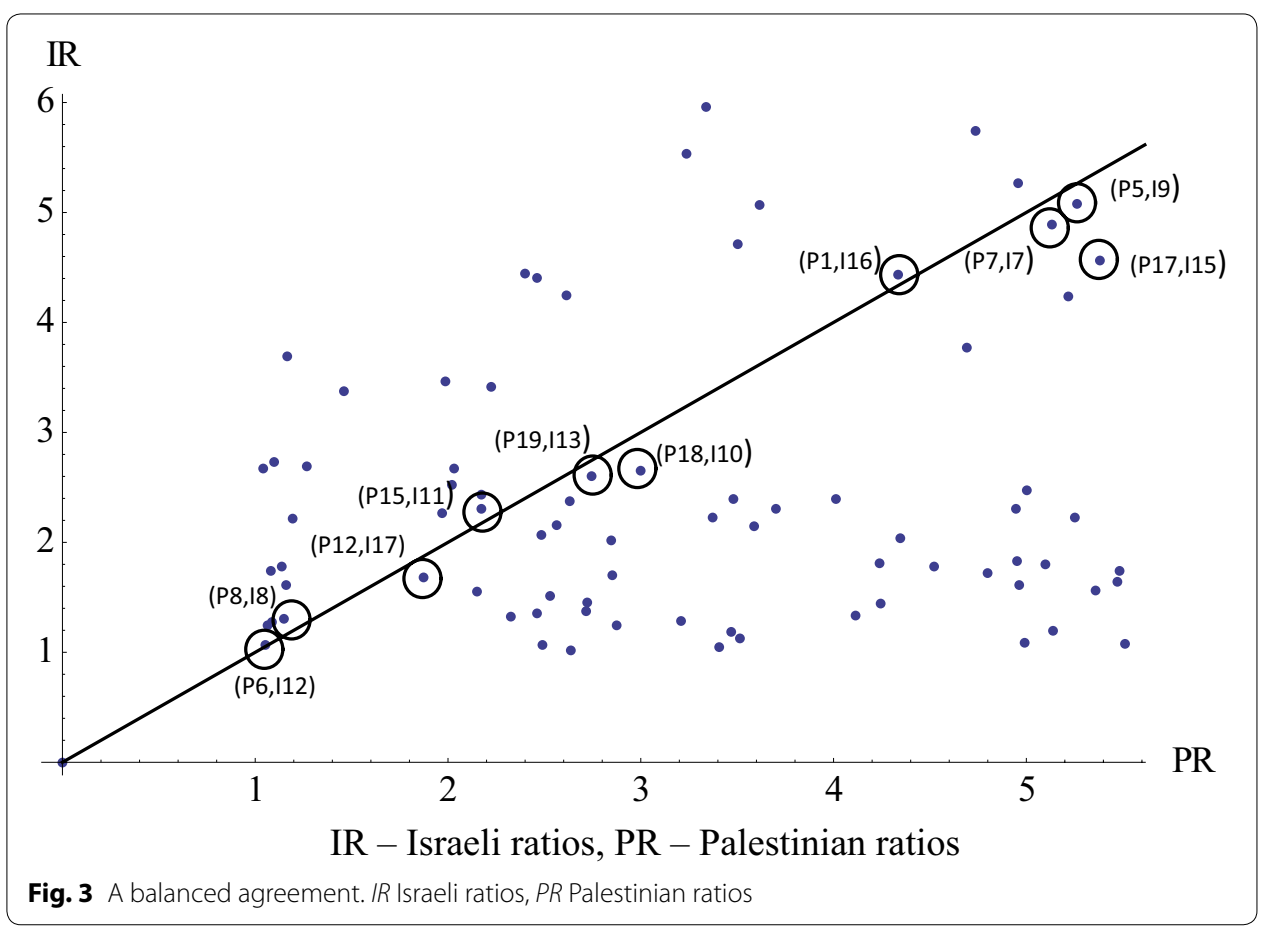

All the critical issues in the conflict: the declaration of the Pittsburgh principles

The data developed above in "Retributive conflicts and the AHP" provided a veritable trove of practical information not previously available to the participants, but based on their own judgments they were now able to understand their own and their protagonists priorities on a wide variety of issues. It became apparent as to which issue on either side had the highest priority for each side, directly asking the question as to what was most important and least important would not have yielded an accurate statement of the trues priorities. The AHP approach addresses such questions in an oblique manner and creates a reality that is far more accurate than trying to achieve an accurate statement by either party. The pairwise comparison approach yielded results which gives each party the kind of understanding of the true problem that can be rarely achieved in face to face negotiations.

Armed with this data, the participants began to consider where agreement might be reached on certain general principles. It became clear that the general principles would be helpful in considering general issues. With full recognition that the devil is in the details, the participants spent considerable time in honing a set of principles that could be agreed upon, word by word, based on knowledge that the AHP approach could provide.

After long hours of interaction, the following general principles, dubbed the Pittsburgh Principles were developed. While it would be presumptuous to suggest that these principles would create a solution to the controversy, participants on both sides felt that the statement of the principles provided a great deal that had eluded the face to face negotiators. All involved understood that the most difficult task of implementing the general principles remained to be addressed. The general principles agreed upon were as follows: 
1. A Two-State solution on the borders of the 4th of June 1967, with mutually agreed upon land swaps.

2. Israel must respect the integrity of the West Bank and Gaza by allowing free and safe passage between the two areas, and the Palestinian State must guarantee that any agreement reached with Israel will be accepted and supported by the majority of the Palestinian people both in Gaza and the West Bank.

3. East Jerusalem is the capital of the Palestinian State. The parties will maintain the status quo of the holy places in Jerusalem.

4. Acknowledge Israel's existence as a Jewish State, without jeopardizing the rights of its minority Israeli citizens.

5. Evacuation of Israeli settlers from the Palestinian territories that are not included in the land swap.

6. Palestinian full control of the borders of the Palestinian State and its outlets, and deployment of a temporary agreed upon multinational military monitoring system in the Jordan Valley.

7. Solve the Palestinian refugee problem in a just and agreed upon manner.

8. Limited arms of the Palestinian state and international guarantees from the international community against aggression from other parties.

9. Agreed upon international monitoring mechanism and agreed upon binding international arbitration mechanisms.

10. The full implementation of these principles concludes end of the conflict and claims of the two parties.

\section{Implementation steps}

In recent months the participants have focused exclusively on developing an implementation plan for each of the Pittsburgh Principles. The outcome of these discussions, using AHP methodology, resulted in a detailed agreement reflecting each of the Pittsburgh Principles, except for \#7 which reads "solve the Palestinian refugee problem in a just and agreed upon manner". This Principle was addressed in an initial implementation mode, but was so complex that we achieved only a few agreed upon details. Several more meetings are planned to complete a fully implementable implementation plan for this principle. Nevertheless, what has been agreed upon so far addresses some of the relevant issues.

While even a detailed implementation plan will require further discussion between the parties, the participants in our study, who are significant members of the Israeli and Palestinian communities, believe that the level of detail presented below will facilitate agreement on these issues, even if some modifications are required.

Principle 1 A Two-State solution on the borders of the 4th of June 1967, with mutually agreed upon land swaps.

The first principle proved to be a difficult statement to implement because it essentially sought to determine the borders of the two entities, a very controversial issue. The participants struggled with an implementation statement, but then decided that a small subgroup would meet separately to try and agree upon the principles for land swaps.

In a meeting in October of 2013 a subcommittee of the participants met at an undisclosed location to draft implementation principles for a land swap. The entire participant group rewrote this material in the format given below. 


\section{Land swap principles}

October 2013.

(Revised January 2014).

\section{General guidelines}

- A Two-State solution on the borders of the 4th of June 1967, with minimal, mutually agreed upon land swap of the same size and of equal value for both sides.

- Territorial contiguity of both states is a principle of importance for both sides.

- Land swap between the State of Israel and the State of Palestine in a manner beneficial to both sides.

- Systematic and time limited process for implementing land swap.

- No swap of land for money.

- No empty Palestinian land or land populated by Palestinians, for swap.

- Tradeoff issues that go beyond land for land could be discussed and should be mutually agreed upon.

- Maximum number of Israeli citizens and minimum Palestinian land to be annexed with proximity to the 1967 line.

- East Jerusalem is an integral part of the West Bank.

- Jewish neighborhoods built in East Jerusalem after 1967 will be part of the land swap.

- The passage between the Gaza Strip and the West Bank will be part of the land swap.

\section{Jerusalem}

Overall arching values relevant to Jerusalem.

- One city two capitals.

- The capital of the State of Palestine will be in East Jerusalem.

- Contiguity of neighborhoods for both sides (minimize isolation of communities).

- Mutually agreed arrangement for the Old City.

- Both sides will work towards agreed upon procedures and arrangements to enable the citizens of the two countries to have access to the city of Jerusalem.

- No Israeli population evacuation with the option of staying under Palestinian sovereignty as individual residents respecting and abiding by Palestinian laws.

- Palestinians living in Jewish neighborhoods in Jerusalem will not be evacuated and will live under Israeli sovereignty.

- Develop road links wherever necessary.

\section{West Bank}

- Israel is responsible to evacuate the settlers who refuse to comply with the agreement.

- The State of Palestine will take full responsibility for the safety of Israeli citizens who choose to stay under Palestinian sovereignty as residents on equal footing with its own citizens.

- The State of Israel will take full responsibility for the safety of Palestinian citizens who choose to stay under Israel sovereignty as residents on equal footing with its own citizens.

- Israel will refrain from any settlement activities in the West Bank or East Jerusalem during the implementation of the agreement. 
Table 14 List of Settlements in the West Bank

\begin{tabular}{|c|c|c|c|c|c|c|c|c|}
\hline & \multicolumn{8}{|c|}{ Israeli settlements } \\
\hline & Name & $\begin{array}{l}\text { Population } \\
2012\end{array}$ & $\begin{array}{l}\text { Builtup } \\
\text { area } \\
\text { (Dunums) }\end{array}$ & Character & Est. & Fence [7] & Council & $\begin{array}{l}\text { Subarea or } \\
\text { bloc }\end{array}$ \\
\hline 3 & Adora & 278 & 159 & Secular & 1984 & $E$ & Har Hebron & West \\
\hline 4 & Alei Zahav & 462 & 255 & Secular & 1982 & W & Shomron & Western S. \\
\hline 5 & $\begin{array}{l}\text { Alfei } \\
\text { Menashe }\end{array}$ & 7574 & 1085 & Secular & 1983 & W & Shomron & $\begin{array}{l}\text { Western S. } \\
\text { [8] }\end{array}$ \\
\hline 6 & Alon Shvut & 3066 & 643 & Religious & 1970 & W & Gush Etzion & Etzion \\
\hline 7 & Almog & 178 & 111 & Secular & 1977 & V & Megilot & Dead Sea \\
\hline 8 & Almon & 1132 & 376 & Secular & 1982 & W & Binyamin & Adumim \\
\hline 9 & Arg aman & 132 & 165 & Secular & 1968 & V & $\begin{array}{l}\text { Bik'at } \\
\text { HaYarden }\end{array}$ & Jordan Valley \\
\hline 10 & Ariel & 18176 & 2479 & Mixed & 1978 & W & Shomron & $\begin{array}{l}\text { Western S. } \\
\text { [9] }\end{array}$ \\
\hline 11 & $\begin{array}{l}\text { Asfar (Met- } \\
\text { zad) }\end{array}$ & 469 & 178 & Orthodox & 1983 & $E$ & Gush Etzion & Judean Mtns \\
\hline 12 & Ateret & 775 & 235 & Religious & 1981 & $E$ & $\begin{array}{l}\text { Mateh Biny- } \\
\text { amin }\end{array}$ & Western B. \\
\hline 13 & Avnat & 119 & & & 1983 & V & Megilot & Dead Sea \\
\hline 14 & Avnei Hefetz & 1614 & 493 & Religious & 1990 & $E$ & Shomron & Western S. \\
\hline 15 & Barkan & 1502 & 349 & Secular & 1981 & W & Shomron & Western S. \\
\hline 16 & Bat Ayin & 1117 & 239 & Religious & 1989 & W & Gush Etzion & Etzion \\
\hline 17 & Beit Aryeh & 4166 & 960 & Secular & 1981 & W & Shomron & $\begin{array}{l}\text { Western S. } \\
\text { [8] }\end{array}$ \\
\hline 18 & Beit El & 5897 & 944 & Religious & 1977 & $E$ & $\begin{array}{l}\text { Mateh Biny- } \\
\text { amin }\end{array}$ & [8] Ramallah \\
\hline 19 & Beit HaArava & 119 & 280 & Secular & 1980 & V & Megilot & Dead Sea \\
\hline 20 & Beit Horon & 1149 & 181 & Mixed & 1977 & W & $\begin{array}{l}\text { Mateh Biny- } \\
\text { amin }\end{array}$ & Giv'on \\
\hline 21 & $\begin{array}{l}\text { Beit Yatir } \\
\text { (Mezadot } \\
\text { Yehuda) }\end{array}$ & 399 & 170 & Religious & 1983 & W & Har Hebron & South \\
\hline 22 & Beitar Illit & 42,467 & 1773 & Orthodox & 1985 & W & Gush Etzion & Etzion [9] \\
\hline 23 & Beka'ot & 175 & 120 & Secular & 1972 & V & $\begin{array}{l}\text { Bik'at } \\
\text { HaYarden }\end{array}$ & Jordan Valley \\
\hline 24 & Carmei Tzur & 872 & 160 & Religious & 1984 & $E$ & Gush Etzion & Etzion \\
\hline 25 & Carmel & 378 & 177 & Religious & 1981 & $\mathrm{E}$ & Har Hebron & South \\
\hline 26 & Dolev & 1306 & 355 & Religious & 1983 & $E$ & $\begin{array}{l}\text { Mateh Biny- } \\
\text { amin }\end{array}$ & Western B. \\
\hline 27 & East Talpiot & 13,984 & 1195 & Secular & 1967 & W & Jerusalem & $\begin{array}{l}\text { East Jerusa- } \\
\text { lem }\end{array}$ \\
\hline 28 & Efrat(a) & 7812 & 1090 & Religious & 1980 & W & Gush Etzion & Etzion [8] \\
\hline 29 & El'azar & 2302 & 256 & Religious & 1975 & W & Gush Etzion & Etzion \\
\hline 30 & Eli & 3521 & 776 & Mixed & 1984 & $E$ & Shomron & Eli \\
\hline 31 & Elkana & 3860 & 758 & Religious & 1977 & W & Shomron & $\begin{array}{l}\text { Western S. } \\
{[8]}\end{array}$ \\
\hline 32 & Elon Moreh & 1632 & 419 & Religious & 1979 & $E$ & Shomron & Nablus \\
\hline 33 & Immanuel & 3660 & 328 & Orthodox & 1983 & W & Shomron & $\begin{array}{l}\text { Western S. } \\
\text { [8] }\end{array}$ \\
\hline 34 & Einav & 662 & 158 & Religious & 1981 & $E$ & Shomron & Enav \\
\hline 35 & Eshkolot & 510 & 133 & Secular & 1982 & W & Har Hebron & South \\
\hline 36 & Etz Efraim & 864 & 184 & Mixed & 1985 & W & Shomron & Western S. \\
\hline
\end{tabular}


Table 14 continued

\begin{tabular}{|c|c|c|c|c|c|c|c|c|}
\hline & \multicolumn{8}{|c|}{ Israeli settlements } \\
\hline & Name & $\begin{array}{l}\text { Population } \\
2012\end{array}$ & $\begin{array}{l}\text { Builtup } \\
\text { area } \\
\text { (Dunums) }\end{array}$ & Character & Est. & Fence [7] & Council & $\begin{array}{l}\text { Subarea or } \\
\text { bloc }\end{array}$ \\
\hline 37 & $\begin{array}{l}\text { French Hill } \\
\text { (Giv'at } \\
\text { Shapira) }\end{array}$ & 8660 & 2018 & Secular & 1969 & W & Jerusalem & $\begin{array}{l}\text { East Jerusa- } \\
\text { lem }\end{array}$ \\
\hline 38 & Ganim & & & & 1983 & $E$ & Shomron & Northern S. \\
\hline 39 & $\begin{array}{l}\text { Geva } \\
\text { Binyamin } \\
\text { (Adam) }\end{array}$ & 4674 & 728 & Secular & 1984 & $E$ & $\begin{array}{l}\text { Mateh Biny- } \\
\text { amin }\end{array}$ & Ramallah \\
\hline 40 & $\begin{array}{l}\text { Gilual, Bik'at } \\
\text { HaYarden }\end{array}$ & 167 & 570 & Secular & 1970 & V & $\begin{array}{l}\text { Bik'at } \\
\text { HaYarden }\end{array}$ & Jordan Valley \\
\hline 41 & Gilo & 29,559 & 2859 & Secular & 1973 & W & Jerusalem & $\begin{array}{l}\text { East Jerusa- } \\
\text { lem }\end{array}$ \\
\hline 42 & Gitit & 308 & 113 & Secular & 1973 & V & $\begin{array}{l}\text { Bik'at } \\
\text { HaYarden }\end{array}$ & Jordan Valley \\
\hline 43 & $\begin{array}{l}\text { Giv'at } \\
\text { Hamivtar }\end{array}$ & 2944 & & & 1970 & W & Jerusalem & $\begin{array}{l}\text { East Jerusa- } \\
\text { lem }\end{array}$ \\
\hline 44 & Giv'at Ze'ev & 13,466 & 1063 & Secular & 1983 & W & $\begin{array}{l}\text { Mateh Biny- } \\
\text { amin }\end{array}$ & [8] Giv'on \\
\hline 45 & $\begin{array}{l}\text { Giv'on Hada- } \\
\text { sha }\end{array}$ & 1131 & 226 & Secular & 1980 & W & $\begin{array}{l}\text { Mateh Biny- } \\
\text { amin }\end{array}$ & Giv'on \\
\hline 46 & Hagai & 541 & 233 & Religious & 1984 & $E$ & Har Hebron & Hebron \\
\hline 47 & Hallamish & 1144 & 450 & Religious & 1977 & E & $\begin{array}{l}\text { Mateh Biny- } \\
\text { amin }\end{array}$ & Western B. \\
\hline 48 & Hamra & 110 & 133 & Secular & 1971 & V & $\begin{array}{l}\text { Bik'at } \\
\text { HaYarden }\end{array}$ & Jordan Valley \\
\hline 49 & $\begin{array}{l}\text { Har Adar } \\
\text { (Giv'at Ha } \\
\text { Radar) }\end{array}$ & 3701 & 969 & Secular & 1986 & W & $\begin{array}{l}\text { Mateh Biny- } \\
\text { amin }\end{array}$ & [8] Giv'on \\
\hline 50 & Har Brakha & 1769 & 258 & & 1983 & $E$ & Shomron & Nablus \\
\hline 51 & Har Gilo & 952 & 127 & Secular & 1972 & W & Gush Etzion & Etzion \\
\hline 52 & $\begin{array}{l}\text { Har Homa, } \\
\text { Givat } \\
\text { Hamatos }\end{array}$ & 9811 & $2523 / 310$ & Religious & 1997 & W & Jerusalem & $\begin{array}{l}\text { East Jerusa- } \\
\text { lem }\end{array}$ \\
\hline 53 & Hashmonaim & 2573 & 835 & $\begin{array}{l}\text { Religious- } \\
\text { Orthodox }\end{array}$ & 1985 & W & $\begin{array}{l}\text { Mateh Biny- } \\
\text { amin }\end{array}$ & Modi'in \\
\hline 54 & Hebron & 850 & & & 1980 & $E$ & Har Hebron & Hebron [11] \\
\hline 55 & $\begin{array}{l}\text { Hemdat } \\
\text { (Nahal) }\end{array}$ & 186 & 82 & N/A & 1980 & V & $\begin{array}{l}\text { Bik'at } \\
\text { HaYarden }\end{array}$ & Jordan Valley \\
\hline 56 & Hermesh & 189 & 134 & Secular & 1982 & $E$ & Shomron & Rehan \\
\hline 57 & Hinanit & 945 & 280 & Mixed & 1981 & W & Shomron & Rehan \\
\hline 58 & Homesh & 0 & 157 & Secular & 1980 & $E$ & Shomron & Northern S. \\
\hline 59 & Itamar & 1024 & 253 & Religious & 1984 & $E$ & Shomron & Nablus \\
\hline 60 & Kadim & 0 & 148 & Secular & 1983 & E & Shomron & Northern S. \\
\hline 61 & Kalia & 360 & 537 & Secular & 1968 & V & Megilot & Dead Sea \\
\hline 62 & $\begin{array}{l}\text { Karnei Shom- } \\
\text { ron }\end{array}$ & 6570 & 1351 & Mixed & 1978 & W & Shomron & $\begin{array}{l}\text { Western S. } \\
\text { [8] }\end{array}$ \\
\hline 63 & Kedar & 1246 & 251 & Secular & 1985 & W & Gush Etzion & Adumim \\
\hline 64 & Kedumim & 4124 & 1003 & Mixed & 1977 & W & Shomron & Kedumim [8] \\
\hline 65 & Kfar Adumim & 3527 & 921 & Mixed & 1979 & W & $\begin{array}{l}\text { Mateh Biny- } \\
\text { amin }\end{array}$ & Adumim \\
\hline 66 & Kfar Etzion & 975 & 445 & Religious & 1967 & W & Gush Etzion & Etzion \\
\hline 67 & Kfar Tapuach & 1207 & 156 & Religious & 1978 & $E$ & Shomron & Western S. \\
\hline 68 & Kiryat Arba & 7593 & 882 & Mixed & 1972 & $E$ & Har Hebron & Hebron [8] \\
\hline
\end{tabular}


Table 14 continued

\begin{tabular}{|c|c|c|c|c|c|c|c|c|}
\hline & \multicolumn{8}{|c|}{ Israeli settlements } \\
\hline & Name & $\begin{array}{l}\text { Population } \\
2012\end{array}$ & $\begin{array}{l}\text { Builtup } \\
\text { area } \\
\text { (Dunums) }\end{array}$ & Character & Est. & Fence [7] & Council & $\begin{array}{l}\text { Subarea or } \\
\text { bloc }\end{array}$ \\
\hline 69 & $\begin{array}{l}\text { Kiryat } \\
\text { Netafim }\end{array}$ & 749 & 162 & Religious & 1983 & W & Shomron & Western S. \\
\hline 70 & $\begin{array}{l}\text { Kokhav } \\
\text { HaShahar }\end{array}$ & 1548 & 586 & Religious & 1977 & V & $\begin{array}{l}\text { Mateh Biny- } \\
\text { amin }\end{array}$ & Jordan \\
\hline 71 & $\begin{array}{l}\text { Kokhav } \\
\text { Ya'akov } \\
\text { (Abir } \\
\text { Ya'akov) }\end{array}$ & 6476 & 756 & Religious & 1985 & E & $\begin{array}{l}\text { Mateh Biny- } \\
\text { amin }\end{array}$ & Ramallah \\
\hline 72 & Lapid & 2543 & 386 & Secular & 1996 & W & $\begin{array}{l}\text { Hevel } \\
\text { Modi'in }\end{array}$ & Modi'in \\
\hline 73 & $\begin{array}{l}\text { Ma'ale } \\
\text { Adumim }\end{array}$ & 36,862 & 3589 & Mixed & 1975 & W & $\begin{array}{l}\text { Gush Etzion } \\
\text { [9] }\end{array}$ & Adumim \\
\hline 74 & Ma'ale Amos & 350 & 155 & Orthodox & 1981 & $E$ & Gush Etzion & Judean Mtns \\
\hline 75 & Ma'ale Efraim & 332 & 521 & Secular & 1970 & V & $\begin{array}{l}\text { Bik'at } \\
\text { HaYarden } \\
\text { [8] }\end{array}$ & Jordan Valley \\
\hline 76 & $\begin{array}{l}\text { Ma'ale } \\
\text { Levona }\end{array}$ & 1119 & 251 & Religious & 1983 & $E$ & $\begin{array}{l}\text { Mateh Biny- } \\
\text { amin }\end{array}$ & Eli \\
\hline 77 & $\begin{array}{l}\text { Ma'ale } \\
\text { Mikhmas }\end{array}$ & 724 & 383 & Religious & 1981 & V & $\begin{array}{l}\text { Mateh Biny- } \\
\text { amin }\end{array}$ & \\
\hline 78 & $\begin{array}{l}\text { Ma'ale Shom- } \\
\text { ron }\end{array}$ & 1251 & 216 & Mixed & 1980 & W & Shomron & Western S. \\
\hline 79 & $\begin{array}{l}\text { Ma'alot } \\
\text { Dafna }\end{array}$ & 2720 & 380 & Secular & 1972 & W & Jerusalem & $\begin{array}{l}\text { East Jerusa- } \\
\text { lem }\end{array}$ \\
\hline 80 & Ma'on & 454 & 173 & Religious & 1981 & $\mathrm{E}$ & Har Hebron & South \\
\hline 81 & Maskiot & 132 & 32 & & 1986 & V & $\begin{array}{l}\text { Bik'at } \\
\text { HaYarden }\end{array}$ & Jordan Valley \\
\hline 82 & Massu'a & 153 & 160 & Secular & 1970 & V & $\begin{array}{l}\text { Bik'at } \\
\text { HaYarden }\end{array}$ & Jordan Valley \\
\hline 83 & Matityahu & 568 & 195 & Religious & 1981 & W & $\begin{array}{l}\text { Mateh Biny- } \\
\text { amin }\end{array}$ & Modi'in \\
\hline 84 & Mehola & 429 & 190 & N/A & 1968 & V & $\begin{array}{l}\text { Bik'at } \\
\text { HaYarden }\end{array}$ & Jordan Valley \\
\hline 85 & Mekhora & 112 & 132 & Secular & 1973 & V & $\begin{array}{l}\text { Bik'at } \\
\text { HaYarden }\end{array}$ & Jordan Valley \\
\hline 86 & Menora & 2644 & 453 & Secular & 1998 & W & $\begin{array}{l}\text { Mateh Biny- } \\
\text { amin }\end{array}$ & Modi'in \\
\hline 87 & Mevo Dotan & 276 & 122 & Secular & 1978 & $E$ & Shomron & Rehan \\
\hline 88 & Mevo Horon & 2147 & 519 & Religious & 1970 & W & $\begin{array}{l}\text { Mateh Biny- } \\
\text { amin }\end{array}$ & Modi'in \\
\hline 89 & Migdal Oz & 512 & 576 & Religious & 1977 & W & Gush Etzion & Etzion \\
\hline 90 & Migdalim & 147 & 130 & Secular & 1983 & $E$ & Shomron & Western S. \\
\hline 91 & $\begin{array}{l}\text { Mishor } \\
\text { Adumim }\end{array}$ & & 1550 & & & & & Adumim \\
\hline 92 & $\begin{array}{l}\text { Mitzpe } \\
\text { Shalem }\end{array}$ & 173 & 151 & Secular & 1971 & V & Megilot & Dead Sea \\
\hline 93 & $\begin{array}{l}\text { Mitzne } \\
\text { Yericho }\end{array}$ & 2115 & 564 & Religious & 1978 & V & $\begin{array}{l}\text { Mateh Biny- } \\
\text { amin }\end{array}$ & Jordan \\
\hline 94 & Modi'in Illit & 55,494 & 1606 & Orthodox & 1996 & W & $\begin{array}{l}\text { Mateh Biny- } \\
\text { amin }\end{array}$ & Modi'in [8] \\
\hline 95 & Na'ale & 1203 & 349 & Secular & 1988 & $E$ & $\begin{array}{l}\text { Mateh Biny- } \\
\text { amin }\end{array}$ & \\
\hline 96 & Nahliel & 496 & 114 & Orthodox & 1984 & $E$ & $\begin{array}{l}\text { Mateh Biny- } \\
\text { amin }\end{array}$ & Western B. \\
\hline
\end{tabular}


Table 14 continued

\begin{tabular}{|c|c|c|c|c|c|c|c|c|}
\hline & \multicolumn{8}{|c|}{ Israeli settlements } \\
\hline & Name & $\begin{array}{l}\text { Population } \\
2012\end{array}$ & $\begin{array}{l}\text { Builtup } \\
\text { area } \\
\text { (Dunums) }\end{array}$ & Character & Est. & Fence [7] & Council & $\begin{array}{l}\text { Subarea or } \\
\text { bloc }\end{array}$ \\
\hline 97 & Negohot & 258 & 90 & Religious & 1999 & E & Har Hebron & West \\
\hline 98 & $\begin{array}{l}\text { Nativ HaG- } \\
\text { dud }\end{array}$ & 162 & 1042 & Secular & 1976 & V & $\begin{array}{l}\text { Bik'at } \\
\text { HaYarden }\end{array}$ & Jordan Valley \\
\hline 99 & Neve Daniel & 2058 & 263 & Religious & 1982 & W & Gush Etzion & Etzion \\
\hline 100 & Neve Yaakov & 19,703 & 1759 & Secular & 1972 & W & Jerusalem & $\begin{array}{l}\text { East Jerusa- } \\
\text { lem }\end{array}$ \\
\hline 101 & Nili & 968 & 282 & Secular & 1981 & E & $\begin{array}{l}\text { Mateh Biny- } \\
\text { amin }\end{array}$ & \\
\hline 102 & Niran & 69 & 302 & Secular & 1977 & V & $\begin{array}{l}\text { Bik'at } \\
\text { HaYarden }\end{array}$ & Jordan Valley \\
\hline 103 & Nofim & 437 & 248 & Secular & 1987 & W & Shomron & Western S. \\
\hline 104 & Nokdim & 1561 & 440 & Mixed & 1982 & $E$ & Gush Etzion & Judean Mtns \\
\hline 105 & Na'omi & 98 & 280 & Secular & 1982 & V & $\begin{array}{l}\text { Bik'at } \\
\text { HaYarden }\end{array}$ & Jordan Valley \\
\hline 106 & Ofarim & $\mathrm{n} / \mathrm{a}$ & 351 & Secular & 1989 & W & $\begin{array}{l}\text { Mateh Biny- } \\
\text { amin }\end{array}$ & \\
\hline 107 & Ofra & 3489 & 1012 & Religious & 1975 & E & $\begin{array}{l}\text { Mateh Biny- } \\
\text { amin }\end{array}$ & Ramallah \\
\hline 108 & $\begin{array}{l}\text { Old City Jew- } \\
\text { ish Quarter }\end{array}$ & 3105 & 156 & Orthodox & & & Jerusalem & $\begin{array}{l}\text { East Jerusa- } \\
\text { lem }\end{array}$ \\
\hline 109 & Oranit & 7195 & 878 & Mixed & 1985 & W & Shomron & $\begin{array}{l}\text { Western S. } \\
\text { [8] }\end{array}$ \\
\hline 110 & Otniel & 927 & 291 & Religious & 1983 & $E$ & Har Hebron & South \\
\hline 111 & Peduel & 1315 & 171 & Religious & 1984 & W & Shomron & Western S. \\
\hline 112 & $\begin{array}{l}\text { Ma'ale Hever } \\
\text { (Peneh } \\
\text { Hever) }\end{array}$ & 398 & 110 & Religious & 1982 & $E$ & $\begin{array}{l}\text { Mateh Biny- } \\
\text { amin }\end{array}$ & Ramallah \\
\hline 113 & Peza'el & 216 & 319 & Secular & 1975 & V & $\begin{array}{l}\text { Bik'at } \\
\text { HaYarden }\end{array}$ & Jordan Valley \\
\hline 114 & Pisgat Ze'ev & 44,512 & 5467 & Secular & 1985 & W & Jerusalem & $\begin{array}{l}\text { East Jerusa- } \\
\text { lem }\end{array}$ \\
\hline 115 & Psagot & 1728 & 234 & Religious & 1981 & $E$ & Har Hebron & Hebron \\
\hline 116 & Ramat Eshkol & 3573 & 682 & Secular & 1970 & W & Jerusalem & $\begin{array}{l}\text { East Jerusa- } \\
\text { lem }\end{array}$ \\
\hline 117 & $\begin{array}{l}\text { Ramat } \\
\text { Shlomo }\end{array}$ & 14,554 & 741 & Orthodox & 1995 & W & Jerusalem & $\begin{array}{l}\text { East Jerusa- } \\
\text { lem }\end{array}$ \\
\hline 118 & Ramot Alon & 41,410 & 2558 & Orthodox & 1974 & W & Jerusalem & $\begin{array}{l}\text { East Jerusa- } \\
\text { lem }\end{array}$ \\
\hline 119 & Rehan & 174 & 90 & Secular & 1977 & W & Shomron & Rehan \\
\hline 120 & Revava & 1545 & 160 & Religious & 1991 & W & Shomron & Western S. \\
\hline 121 & Rimonim & 572 & 314 & Secular & 1977 & V & $\begin{array}{l}\text { Mateh Biny- } \\
\text { amin }\end{array}$ & Jordan \\
\hline 122 & Ro'i & 154 & 134 & Secular & 1976 & V & $\begin{array}{l}\text { Bik'at } \\
\text { HaYarden }\end{array}$ & Jordan Valley \\
\hline 123 & Rosh Tzurim & 855 & 320 & Religious & 1969 & W & Gush Etzion & Etzion \\
\hline 124 & $\begin{array}{l}\text { Sanhedria } \\
\text { Murhevet }\end{array}$ & 4094 & 378 & & 1970 & W & Jerusalem & $\begin{array}{l}\text { East Jerusa- } \\
\text { lem }\end{array}$ \\
\hline 125 & Sa-Nur & 0 & 44 & Secular & 1982 & $E$ & Shomron & Northern S. \\
\hline 126 & Sal'it & 542 & 256 & Secular & 1977 & W & Shomron & Enav \\
\hline 127 & Sha'are Tikva & 5100 & 915 & Mixed & 1983 & W & Shomron & Western S. \\
\hline 128 & $\begin{array}{r}\text { Shadmot } \\
\text { Mehola }\end{array}$ & 512 & 159 & N/A & 1979 & V & $\begin{array}{l}\text { Bik'at } \\
\text { HaYarden }\end{array}$ & Jordan Valley \\
\hline
\end{tabular}


Table 14 continued

\begin{tabular}{|c|c|c|c|c|c|c|c|c|}
\hline & \multicolumn{8}{|c|}{ Israeli settlements } \\
\hline & Name & $\begin{array}{l}\text { Population } \\
2012\end{array}$ & $\begin{array}{l}\text { Builtup } \\
\text { area } \\
\text { (Dunums) }\end{array}$ & Character & Est. & Fence [7] & Council & $\begin{array}{l}\text { Subarea or } \\
\text { bloc }\end{array}$ \\
\hline 129 & Shaked & 724 & 206 & Secular & 1981 & W & Shomron & Rehan \\
\hline 130 & Shani & 430 & 30 & Secular & 1989 & W & Har Hebron & South \\
\hline 131 & $\begin{array}{l}\text { Shavei } \\
\text { Shomron }\end{array}$ & 745 & 272 & Religious & 1977 & $E$ & Shomron & Western S. \\
\hline 132 & Shilo & 2706 & 482 & Religious & 1979 & $E$ & $\begin{array}{l}\text { Mateh Biny- } \\
\text { amin }\end{array}$ & Eli \\
\hline 133 & Shim'a & 375 & 212 & Secular & 1985 & $E$ & Har Hebron & South \\
\hline 134 & Shvut Rachel & 400 & & & 1991 & $E$ & $\begin{array}{l}\text { Mateh Biny- } \\
\text { amin }\end{array}$ & Eli \\
\hline 135 & Susiya & 950 & 352 & Religious & 1983 & $E$ & Har Hebron & South \\
\hline 136 & Talmon & 3202 & 1135 & Religious & 1989 & $E$ & $\begin{array}{l}\text { Mateh Biny- } \\
\text { amin }\end{array}$ & Western B. \\
\hline 137 & Tekoa & 2518 & 402 & Mixed & 1977 & $E$ & Gush Etzion & Judean Mtns \\
\hline 138 & Telem & 241 & 117 & Secular & 1982 & $E$ & Har Hebron & West \\
\hline 139 & Tene Omarim & 658 & 272 & Secular & 1983 & $E$ & Har Hebron & South \\
\hline 140 & Tomer & 228 & 362 & Secular & 1978 & V & $\begin{array}{l}\text { Bik'at } \\
\text { HaYarden }\end{array}$ & Jordan Valley \\
\hline 141 & Vered Jericho & 221 & 274 & Secular & 1980 & V & Megilot & Dead Sea \\
\hline 142 & Yafit & 124 & 352 & Secular & 1980 & V & $\begin{array}{l}\text { Bik'at } \\
\text { HaYarden }\end{array}$ & Jordan Valley \\
\hline 143 & Yakir & 1645 & 342 & Religious & 1981 & W & Shomron & Western S. \\
\hline 144 & Yitav & 195 & 170 & Secular & 1970 & V & $\begin{array}{l}\text { Bik'at } \\
\text { HaYarden }\end{array}$ & Jordan Valley \\
\hline 145 & Yitzhar & 1172 & 269 & Religious & 1983 & $E$ & Shomron & Nablus \\
\hline 146 & Zofin & 1484 & 219 & Mixed & 1989 & W & Shomron & Kedumim \\
\hline
\end{tabular}

Today there are 144 Israeli settlements in the West Bank (see Table 14) and an unknown number of outposts. Israel wants to annex 43 of the settlements in exchange for land in other parts of Israel (see Table 15). The other settlements will have to be disposed of appropriately. These settlements contain about $74.58 \%$ of the population in the settlements, and cover an area of approximately $3.1 \%$ of the area of the West Bank or 182 sq. km. The maps in Figs. 4 and 5 show the settlements in Table 10 (marked in yellow) to be annexed by Israel in this solution.

Figure 6 contains the map of territories proposed by Israeli participants for land swap in exchange for the territories annexed in Table 15 and depicted in Figs. 4 and 5. The proposed land swap alternatives were evaluated in Table 16.

\section{Result}

The total area to be annexed by Israel is $3.1 \%$ of the West Bank or $182 \mathrm{~km}^{2}$. The corresponding land from the sites prioritized above is selected by using the quality points from the final scores as follows: Beit Shean Valley $\left(18 \mathrm{~km}^{2}\right)$, Gaza Envelop $\left(67.7 \mathrm{~km}^{2}\right)$, Judea Plain $\left(63.4 \mathrm{~km}^{2}\right)$ and Northern Negev $\left(32.9 \mathrm{~km}^{2}\right)$.

Principle 2 Israel must respect the integrity of the West Bank and Gaza by allowing free and safe passage between the two areas, and the Palestinian State must guarantee 
Table 15 List of settlements in the West Bank to be annexed by Israel

\begin{tabular}{|c|c|c|c|c|c|c|c|c|}
\hline \multicolumn{9}{|c|}{ Israeli settlements } \\
\hline Name & $\begin{array}{l}\text { Popula- } \\
\text { tion } 2012\end{array}$ & $\begin{array}{l}\text { Builtup } \\
\text { area } \\
\text { (Dunums) }\end{array}$ & Character & Est. & Fence [7] & Council & $\begin{array}{l}\text { Subarea } \\
\text { or bloc }\end{array}$ & $\begin{array}{l}\text { Under } \\
\text { Israeli Flag }\end{array}$ \\
\hline $\begin{array}{l}\text { Alfei } \\
\text { Menashe }\end{array}$ & 7574 & 1085 & Secular & 1983 & w & Shomron & $\begin{array}{l}\text { Western S. } \\
\text { [8] }\end{array}$ & y \\
\hline Alon Shvut & 3066 & 643 & Religious & 1970 & w & $\begin{array}{l}\text { Gush } \\
\text { Etzion }\end{array}$ & Etzion & y \\
\hline Bat Ayin & 1117 & 239 & Religious & 1989 & w & $\begin{array}{l}\text { Gush } \\
\text { Etzion }\end{array}$ & Etzion & y \\
\hline $\begin{array}{l}\text { Beit Yatir } \\
\text { (Mezadot } \\
\text { Yehuda) }\end{array}$ & 399 & 170 & Religious & 1983 & w & $\begin{array}{l}\text { Har } \\
\text { Hebron }\end{array}$ & South & y \\
\hline Beitar Illit & 42,467 & 1773 & Orthodox & 1985 & w & $\begin{array}{l}\text { Gush } \\
\text { Etzion }\end{array}$ & Etzion [9] & y \\
\hline East Talpiot & 13,984 & 1195 & Secular & 1967 & w & Jerusalem & $\begin{array}{l}\text { East Jeru- } \\
\text { salem }\end{array}$ & y \\
\hline Efrat(a) & 7812 & 1090 & Religious & 1980 & w & $\begin{array}{l}\text { Gush } \\
\text { Etzion }\end{array}$ & Etzion [8] & y \\
\hline El'azar & 2302 & 256 & Religious & 1975 & w & $\begin{array}{l}\text { Gush } \\
\text { Etzion }\end{array}$ & Etzion & y \\
\hline Elkana & 3860 & 758 & Religious & 1977 & w & Shomron & $\begin{array}{l}\text { Western S. } \\
{[8]}\end{array}$ & y \\
\hline Eshkolot & 510 & 133 & Secular & 1982 & w & $\begin{array}{l}\text { Har } \\
\text { Hebron }\end{array}$ & South & y \\
\hline Etz Efraim & 864 & 184 & Mixed & 1985 & w & Shomron & Western S. & y \\
\hline $\begin{array}{l}\text { French Hill } \\
\text { (Giv'at } \\
\text { Shapira) }\end{array}$ & 8660 & 2018 & Secular & 1969 & w & Jerusalem & $\begin{array}{l}\text { East Jeru- } \\
\text { salem }\end{array}$ & y \\
\hline Gilo & 29,559 & 2859 & Secular & 1973 & w & Jerusalem & $\begin{array}{l}\text { East Jeru- } \\
\text { salem }\end{array}$ & y \\
\hline $\begin{array}{l}\text { Giv'at } \\
\text { Hamivtar }\end{array}$ & 2944 & & & 1970 & w & Jerusalem & $\begin{array}{l}\text { East Jeru- } \\
\text { salem }\end{array}$ & y \\
\hline Giv'at Ze'ev & 13,466 & 1063 & Secular & 1983 & w & $\begin{array}{l}\text { Mateh } \\
\text { Biny- } \\
\text { amin }\end{array}$ & [8] Giv'on & $y$ \\
\hline $\begin{array}{l}\text { Giv'on } \\
\text { Hadasha }\end{array}$ & 1131 & 226 & Secular & 1980 & w & $\begin{array}{l}\text { Mateh } \\
\text { Biny- } \\
\text { amin }\end{array}$ & Giv'on & $y$ \\
\hline $\begin{array}{l}\text { Har Adar } \\
\text { (Giv'at } \\
\text { HaRadar) }\end{array}$ & 3701 & 969 & Secular & 1986 & w & $\begin{array}{l}\text { Mateh } \\
\text { Biny- } \\
\text { amin }\end{array}$ & [8] Giv'on & $y$ \\
\hline $\begin{array}{l}\text { Har Homa, } \\
\text { Givat } \\
\text { Hamatos }\end{array}$ & 9811 & $2523 / 310$ & Religious & 1997 & w & Jerusalem & $\begin{array}{l}\text { East Jeru- } \\
\text { salem }\end{array}$ & $y$ \\
\hline $\begin{array}{l}\text { Hash- } \\
\text { monaim }\end{array}$ & 2573 & 835 & $\begin{array}{l}\text { Religious- } \\
\text { Ortho- } \\
\text { dox }\end{array}$ & 1985 & w & $\begin{array}{l}\text { Mateh } \\
\text { Biny- } \\
\text { amin }\end{array}$ & Modi'in & $y$ \\
\hline Hinanit & 945 & 280 & Mixed & 1981 & w & Shomron & Rehan & $y$ \\
\hline Kfar Etzion & 975 & 445 & Religious & 1967 & w & $\begin{array}{l}\text { Gush } \\
\text { Etzion }\end{array}$ & Etzion & $y$ \\
\hline Lapid & 2543 & 386 & Secular & 1996 & w & $\begin{array}{l}\text { Hevel } \\
\text { Modi'in }\end{array}$ & Modi'in & $y$ \\
\hline $\begin{array}{l}\text { Ma'ale } \\
\text { Adumim }\end{array}$ & 36,862 & 3589 & Mixed & 1975 & w & $\begin{array}{l}\text { Gush } \\
\text { Etzion } \\
{[9]}\end{array}$ & Adumim & $y$ \\
\hline $\begin{array}{l}\text { Ma'alot } \\
\text { Dafna }\end{array}$ & 2720 & 380 & Secular & 1972 & w & Jerusalem & $\begin{array}{l}\text { East Jeru- } \\
\text { salem }\end{array}$ & $y$ \\
\hline
\end{tabular}


Table 15 continued

\begin{tabular}{|c|c|c|c|c|c|c|c|c|}
\hline \multicolumn{9}{|c|}{ Israeli settlements } \\
\hline Name & $\begin{array}{l}\text { Popula- } \\
\text { tion } 2012\end{array}$ & $\begin{array}{l}\text { Builtup } \\
\text { area } \\
\text { (Dunums) }\end{array}$ & Character & Est. & Fence [7] & Council & $\begin{array}{l}\text { Subarea } \\
\text { or bloc }\end{array}$ & $\begin{array}{l}\text { Under } \\
\text { Israeli Flag }\end{array}$ \\
\hline Matitvahu & 568 & 195 & Religious & 1981 & w & $\begin{array}{l}\text { Mateh } \\
\text { Biny- } \\
\text { amin }\end{array}$ & Modi'in & $y$ \\
\hline Menora & 2644 & 453 & Secular & 1998 & w & $\begin{array}{l}\text { Mateh } \\
\text { Biny- } \\
\text { amin }\end{array}$ & Modi'in & y \\
\hline Migdal Oz & 512 & 576 & Religious & 1977 & w & $\begin{array}{l}\text { Gush } \\
\text { Etzion }\end{array}$ & Etzion & y \\
\hline Modi'in Illit & 55494 & 1606 & Orthodox & 1996 & w & $\begin{array}{l}\text { Mateh } \\
\text { Biny- } \\
\text { amin }\end{array}$ & Modi'in [8] & y \\
\hline $\begin{array}{l}\text { Neve } \\
\text { Daniel }\end{array}$ & 2058 & 263 & Religious & 1982 & w & $\begin{array}{l}\text { Gush } \\
\text { Etzion }\end{array}$ & Etzion & y \\
\hline $\begin{array}{l}\text { Neve } \\
\text { Yaakov }\end{array}$ & 19,703 & 1759 & Secular & 1972 & w & Jerusalem & $\begin{array}{l}\text { East Jeru- } \\
\text { salem }\end{array}$ & y \\
\hline Oranit & 7195 & 878 & Mixed & 1985 & w & Shomron & $\begin{array}{l}\text { Western S. } \\
\text { [8] }\end{array}$ & $y$ \\
\hline Pisgat Ze'ev & 44,512 & 5467 & Secular & 1985 & w & Jerusalem & $\begin{array}{l}\text { East Jeru- } \\
\text { salem }\end{array}$ & y \\
\hline $\begin{array}{l}\text { Ramat } \\
\text { Eshkol }\end{array}$ & 3573 & 682 & Secular & 1970 & w & Jerusalem & $\begin{array}{l}\text { East Jeru- } \\
\text { salem }\end{array}$ & y \\
\hline $\begin{array}{l}\text { Ramat } \\
\text { Shlomo }\end{array}$ & 14,554 & 741 & Orthodox & 1995 & w & Jerusalem & $\begin{array}{l}\text { East Jeru- } \\
\text { salem }\end{array}$ & y \\
\hline Ramot Alon & 41,410 & 2558 & Orthodox & 1974 & w & Jerusalem & $\begin{array}{l}\text { East Jeru- } \\
\text { salem }\end{array}$ & y \\
\hline Rehan & 174 & 90 & Secular & 1977 & w & Shomron & Rehan & y \\
\hline $\begin{array}{l}\text { Rosh } \\
\text { Tzurim }\end{array}$ & 855 & 320 & Religious & 1969 & w & $\begin{array}{l}\text { Gush } \\
\text { Etzion }\end{array}$ & Etzion & y \\
\hline $\begin{array}{l}\text { Sanhedria } \\
\text { Murhevet }\end{array}$ & 4094 & 378 & & 1970 & w & Jerusalem & $\begin{array}{l}\text { East Jeru- } \\
\text { salem }\end{array}$ & y \\
\hline Sal'it & 542 & 256 & Secular & 1977 & w & Shomron & Enav & $y$ \\
\hline $\begin{array}{c}\text { Sha'are } \\
\text { Tikva }\end{array}$ & 5100 & 915 & Mixed & 1983 & w & Shomron & Western S. & y \\
\hline Shaked & 724 & 206 & Secular & 1981 & w & Shomron & Rehan & $y$ \\
\hline Shani & 430 & 30 & Secular & 1989 & w & $\begin{array}{l}\text { Har } \\
\text { Hebron }\end{array}$ & South & $y$ \\
\hline Zofin & 1484 & 219 & Mixed & 1989 & w & Shomron & Kedumim & $y$ \\
\hline \multirow{7}{*}{$\begin{array}{l}\text { Total (excl. } \\
\text { East Jeru- } \\
\text { salem): }\end{array}$} & 345,037 & & $\begin{array}{l}\text { Total } \\
\text { Dunums }\end{array}$ & & & & & \\
\hline & & & 74,681 & & & & & \\
\hline & & $\begin{array}{l}\text { West Bank } \\
\text { Area }\end{array}$ & $5,876,000$ & & & & & \\
\hline & & $\begin{array}{l}\text { Annexed } \\
\text { Area }\end{array}$ & 182,156 & $3.1 \%$ & & & & \\
\hline & & $\begin{array}{l}\text { Built up } \\
\text { Area }\end{array}$ & 38,168 & $0.650 \%$ & & & & \\
\hline & & Population & 405,471 & $74.58 \%$ & & & & \\
\hline & & Relocated & 138,195 & $25.42 \%$ & & & & \\
\hline
\end{tabular}






Fig. 4 Settlements to be annexed by Israel in the West Bank 




that any agreement reached with Israel will be accepted and supported by the majority of the Palestinian people both in Gaza and the West Bank.

The implementation of Principle 2 reflects the feeling of both parties that any peace agreement should be subject to a referendum in each society so that the will of the 


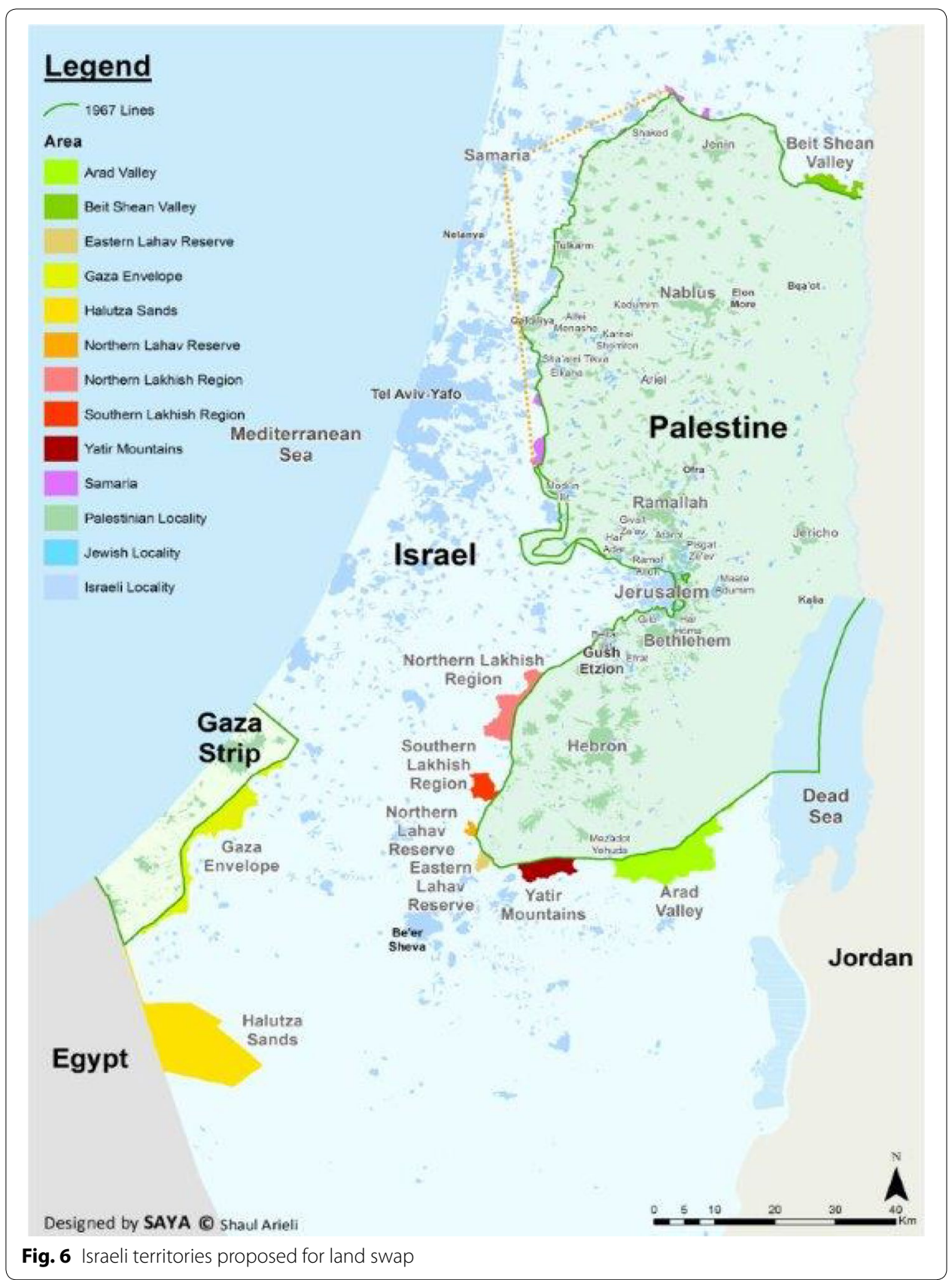

people of both communities becomes apparent. The consensus of the representatives from both sides was that a significant proportion of their respective populations desired peace, if given the opportunity on a plan their leaders approve. Further, the Israeli representatives agreed that there should be free passage between Gaza and the West Bank without any restrictions in moving from one area to the other. This meant that some sort of corridor over Israeli land would be required.

Principle 3 East Jerusalem is the capital of the Palestinian State. The parties will maintain the status quo of the holy places in Jerusalem.

The participants agreed on the following principles for the historic area of Jerusalem. 
Table 16 Land swap evaluation

\begin{tabular}{|c|c|c|c|c|c|c|c|c|c|}
\hline \multirow[t]{2}{*}{ Criteria: } & \multirow{2}{*}{$\begin{array}{l}\text { Area } \\
\left(\mathrm{km}^{2}\right)\end{array}$} & \multirow{2}{*}{$\begin{array}{l}\text { Natural } \\
\text { resources }\end{array}$} & \multicolumn{6}{|c|}{ Goal: evaluation of land swap } & \multirow{2}{*}{$\begin{array}{l}\text { Final } \\
\text { scores }\end{array}$} \\
\hline & & & $\begin{array}{l}\text { Size } \\
(0.02)\end{array}$ & $\begin{array}{l}\text { Location } \\
(0.28)\end{array}$ & $\begin{array}{l}\text { Infra- } \\
\text { structure } \\
(0.05)\end{array}$ & $\begin{array}{l}\text { Natural } \\
\text { resources } \\
(0.29)\end{array}$ & $\begin{array}{l}\text { Ter- } \\
\text { ritorial } \\
\text { conti- } \\
\text { guity } \\
(0.29)\end{array}$ & $\begin{array}{l}\text { Potential } \\
\text { for devel- } \\
\text { opment } \\
(0.06)\end{array}$ & \\
\hline \multicolumn{10}{|l|}{ Alternatives: } \\
\hline $\begin{array}{l}\text { Beit Shean } \\
\text { Valley }\end{array}$ & 18 & $\begin{array}{l}\text { Orchards } \\
\text { green- } \\
\text { houses } \\
\text { veg- } \\
\text { etables } \\
\text { fisheries }\end{array}$ & 0.6 & 0.79 & 0.86 & 0.79 & 0.9 & 0.95 & 0.83 \\
\hline Judea Plain & & $\begin{array}{l}\text { Agriculture } \\
\text { pasture } \\
\text { lands }\end{array}$ & 0.8 & 0.79 & 0.56 & 0.56 & 0.79 & 0.82 & 0.71 \\
\hline $\begin{array}{l}\text { Northern } \\
\text { Lakhish } \\
\text { Region }\end{array}$ & 37.3 & & & & & & & & \\
\hline $\begin{array}{l}\text { Southern } \\
\text { Lakhish } \\
\text { Region }\end{array}$ & 16.2 & & & & & & & & \\
\hline $\begin{array}{l}\text { Northern } \\
\text { Lahav } \\
\text { Reserve }\end{array}$ & 3.8 & & & & & & & & \\
\hline $\begin{array}{l}\text { Eastern } \\
\text { Lahav } \\
\text { Reserve }\end{array}$ & 6.1 & & & & & & & & \\
\hline $\begin{array}{l}\text { Northern } \\
\text { Negev }\end{array}$ & & & 0.6 & 0.5 & 0.21 & 0.38 & 0.5 & 0.44 & 0.45 \\
\hline Arad Valley & 93.5 & $\begin{array}{c}\text { Forestry } \\
\text { Agri- } \\
\text { culture } \\
\text { Nature } \\
\text { Reserve }\end{array}$ & & & & & & & \\
\hline $\begin{array}{l}\text { Yatir Moun- } \\
\text { tains }\end{array}$ & 26.9 & Vineyards & & & & & & & \\
\hline $\begin{array}{l}\text { Gaza } \\
\text { Envelop }\end{array}$ & 67.7 & $\begin{array}{l}\text { Orchards } \\
\text { green- } \\
\text { houses } \\
\text { veg- } \\
\text { etables } \\
\text { nature } \\
\text { reserve }\end{array}$ & 0.9 & 0.82 & 0.69 & 0.75 & 0.86 & 0.86 & 0.81 \\
\hline $\begin{array}{l}\text { Halutza } \\
\text { Sands }\end{array}$ & 178.1 & Aquifer & 0 & 0 & 0 & 0 & 0 & 0.06 & 0 \\
\hline
\end{tabular}

Evaluation of the five locations for land swap in terms of their potential to fulfill the five criteria listed

\section{Principles and special arrangements for the historic area of Jerusalem}

1. The 'Historic Area' includes Mt. Zion, the Kidron Valley, the Jewish Cemetery in the Mt. of Olives, the City of King David and the Old City as shown in Fig. 7.

2. This area will function in the model of "Open City". Citizens of either party may not exit this area into the territory of the other party.

3. Upon the implementation of the principles, Palestine will assume sovereignty over the entire area, excluding the Jewish Quarter and Mount Zion (as in Fig. 8).

4. Palestinians will have control over the Haram al-Sharif and Israelis will have control over the Wailing Wall (no one will have sovereignty over these sites).

5. The religious status quo and particularly the existing arrangements pertaining to the exercise of religious practices will remain. 


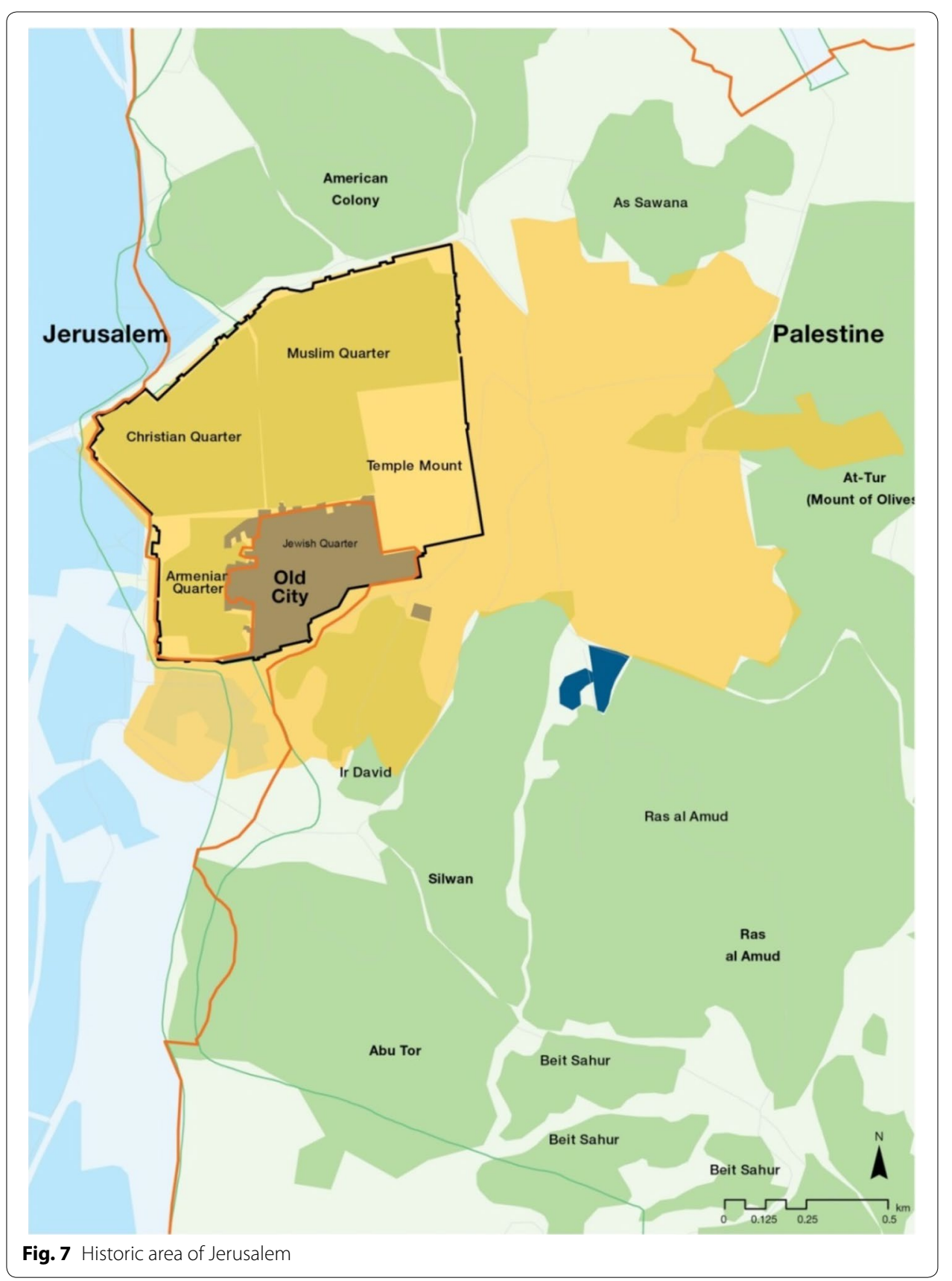

6. The implementation of these principles will be carried out according to the following three stages. A detailed time table will be agreed upon by the parties:

a. Redeployment of the Israeli Defense Forces and Israeli population from the Palestinian areas.

b. A multinational force will help assume responsibility in the territory pertaining to the Palestinians.

c. The State of Palestine assumes full control over its part of the area. 


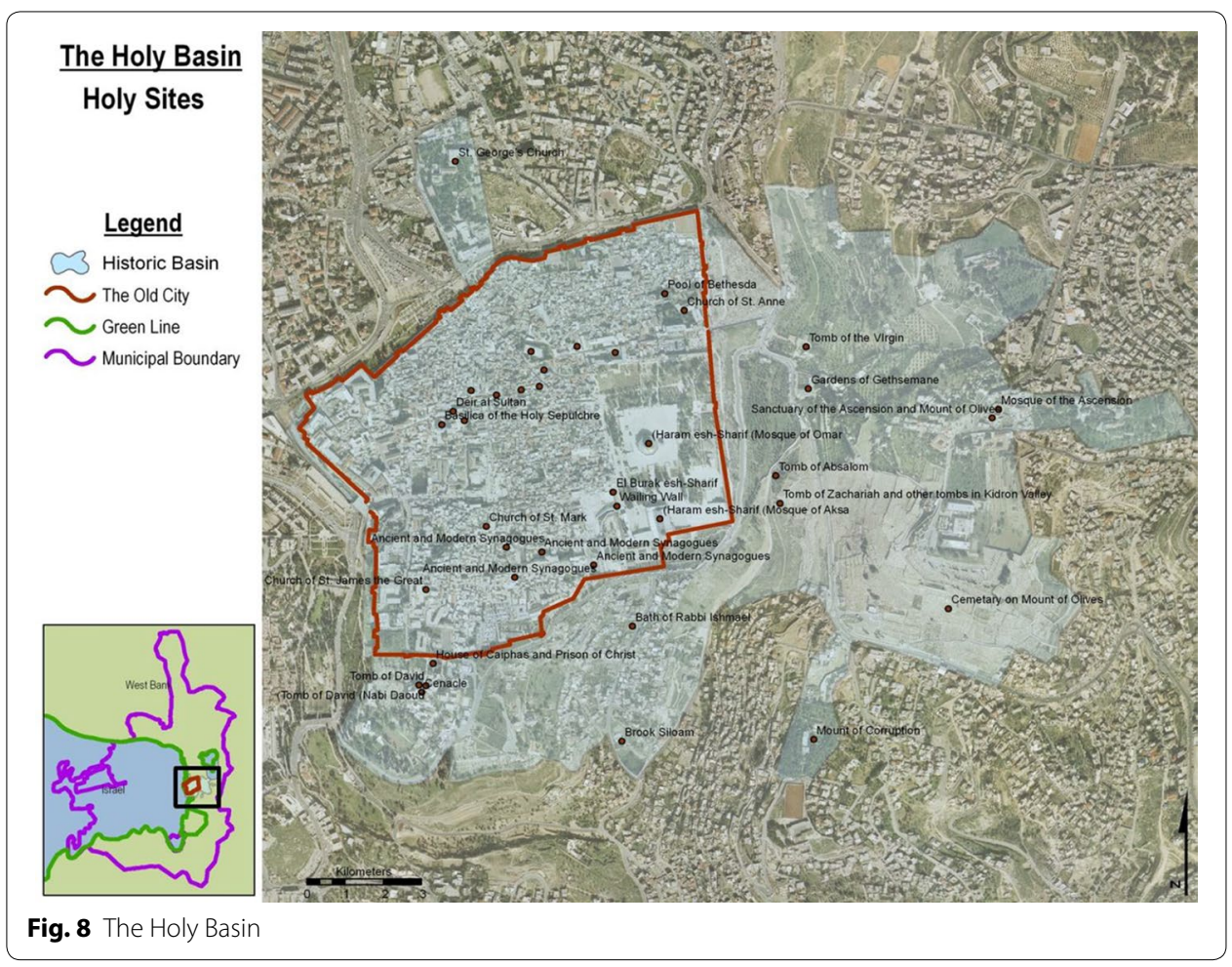

In addition, to the agreed upon facts noted above, the participants developed a series of actions (concessions) for each side. Next, the concessions were prioritized with respect to the benefits, costs, perceived benefits and perceived costs. Tables 17 and 18 summarize the priorities assigned and represent the judgments of the participants using the ratings approach of the AHP.

The priorities of the concessions with respect to the benefits, costs, perceived benefits and perceived costs (see Table 19) are combined to produce the gain ratios used to make trade-offs among the concessions. In this principle a pair of concessions, considered as a bundle, is traded as shown below.

As a result of these matched concessions the actions to be required of each party will be as follows:

\section{Israeli actions}

- Rescind all legal and administrative measures and orders legislated by Israel since 1967.

- Preserve and respect the status quo of the holy places in the city as decreed and accepted by the Ottomans and the international community in 1856.

\section{Palestinian actions}

- Full Palestinian cooperation during transfer of power and beyond it.

- Acceptance of international monitoring on the compliance of the transfer of power process.

Principle 4 Acknowledge Israel's Existence as a Jewish State without jeopardizing the rights of its minority Israeli citizens. 
Table 17 Summary of assigned priorities (Israeli perspective) for Principle 3

\begin{tabular}{|c|c|c|c|c|}
\hline Israeli benefits from Palestinian concessions & Priorities & P1 & \multicolumn{2}{|l|}{ P2 } \\
\hline $\begin{array}{l}\text { Accepting the global recognition of Jerusalem (in its new borders) as the } \\
\text { capital of Israel }\end{array}$ & 0.2812 & 0.6 & \multicolumn{2}{|c|}{0.688} \\
\hline Increasing international and regional support for Israel & 0.1508 & 0.75 & \multicolumn{2}{|c|}{0.663} \\
\hline $\begin{array}{l}\text { Transfer of full governmental and municipal responsibility for the Palestinian } \\
\text { residents of Eastern Jerusalem, while sharing social costs }\end{array}$ & 0.0587 & 0 & \multicolumn{2}{|l|}{0} \\
\hline Security & 0.0481 & 0 & \multicolumn{2}{|l|}{0} \\
\hline $\begin{array}{l}\text { Receiving international legitimization to the Jewish neighborhood in East } \\
\text { Jerusalem }\end{array}$ & 0.2189 & 0.625 & \multicolumn{2}{|c|}{0.575} \\
\hline \multirow[t]{2}{*}{ Strengthen Israeli democracy } & \multirow[t]{2}{*}{0.2423} & \multirow{2}{*}{$\begin{array}{l}0.438 \\
0.5246\end{array}$} & \multicolumn{2}{|c|}{0.055} \\
\hline & & & \multicolumn{2}{|c|}{0.4324} \\
\hline Israeli costs from Israeli concessions & Priorities I & 11 & 12 & 13 \\
\hline $\begin{array}{l}\text { Hurting the feelings of the global Jewish people by conceding on the right } \\
\text { of Jews to live everywhere in Jerusalem }\end{array}$ & 0.2255 & 0.402 & 0.875 & 0.12 \\
\hline $\begin{array}{l}\text { Increasing potential friction due to the dual management of the city, } \\
\text { increasing inefficiencies }\end{array}$ & 0.1582 & 0.173 & 0.967 & 0.12 \\
\hline $\begin{array}{l}\text { Hindering the ability to effectively zone and plan super-infrastructure inside } \\
\text { and around Jerusalem }\end{array}$ & 0.0954 & 0.283 & 0.533 & 0.287 \\
\hline Loss of security control & 0.4271 & 0.317 & 0.587 & 0.67 \\
\hline \multirow[t]{2}{*}{ Loss of demographic control } & \multirow[t]{2}{*}{0.0938} & 0.37 & 0.503 & 0.553 \\
\hline & & 0.3152 & 0.6989 & 0.4115 \\
\hline Israeli perception of Palestinian benefits from Israeli concessions & Priorities $\mathrm{I}$ & 11 & 12 & 13 \\
\hline Fulfill our national aspiration and dignity & 0.3699 & 0.503 & 0.667 & 0.637 \\
\hline Enforcing the Palestinian national identity & 0.2964 & 0.587 & 0.367 & 0.587 \\
\hline Free worship of the three monotheistic religions & 0.0562 & 0 & 0 & 0 \\
\hline Social benefit by preserving the social fabric & 0.1266 & 0.387 & 0.07 & 0.203 \\
\hline \multirow{2}{*}{$\begin{array}{l}\text { Economic benefit by developing the tourism industry and other aspects of } \\
\text { life in the city }\end{array}$} & \multirow[t]{2}{*}{0.1509} & 0.1 & 0.07 & 0.583 \\
\hline & & 0.4241 & 0.3747 & 0.5232 \\
\hline Israeli perception of Palestinian costs from Palestinian concessions & Priorities & P1 & P2 & \\
\hline $\begin{array}{l}\text { Political costs by accepting compromise within the land swap approach on } \\
\text { parts of the city where Israeli settlements exist }\end{array}$ & 0.5905 & 0.883 & 0.367 & \\
\hline Limiting the potential urban, economic and social development of the city & 0.4095 & 0.317 & 0.337 & \\
\hline & & 0.6513 & 30.354 & \\
\hline Palestinian actions & & & & \\
\hline P1. Full Palestinian cooperation during transfer of power and beyond it & & & & \\
\hline $\begin{array}{l}\text { P2. Accepting international monitoring on the compliance of the transfer of } \\
\text { process }\end{array}$ & power & & & \\
\hline
\end{tabular}

This principle does not deny non-Jewish Israeli citizens the full rights of Israeli citizenship. Principle 5 Evacuation of Israeli settlers from the Palestinian territories who are not included in the land swap (see Tables 20, 21 and 22).

\section{Israeli perspective}

Benefits

1. Security benefits.

2. Social and economic benefits. 
Table 18 Summary of Assigned Priorities (Palestinian Perspective) for Principle 3

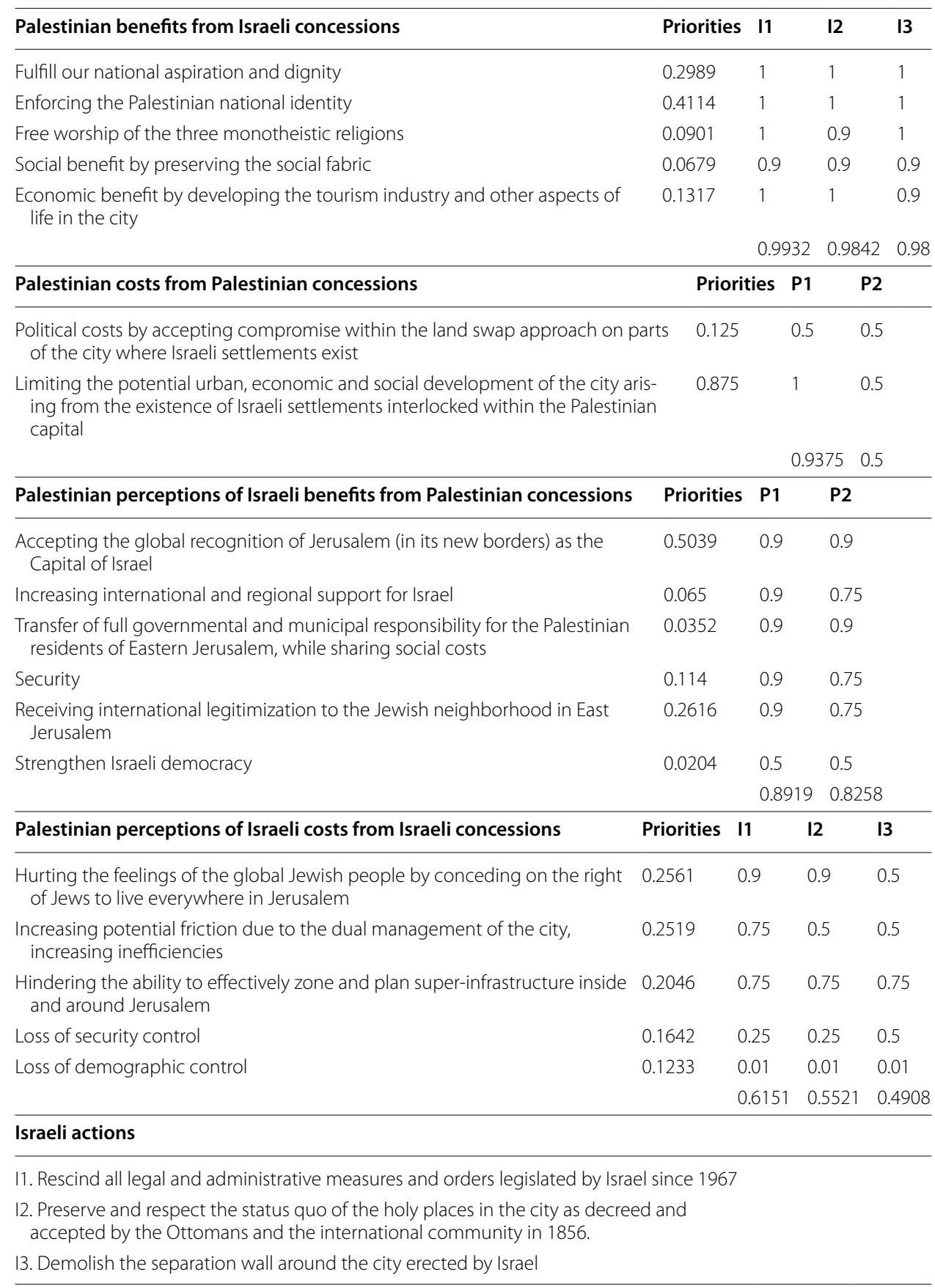

3. Increase in the effectiveness of military and police forces.

4. Allow Israel to define its borders.

5. Increased international support.

6. Strengthen the democratic nature of the state of Israel.

Costs

1. Economic cost to relocate the settlers.

2. Rift in the Israeli society, danger of civil war/Jewish terror. 
Table 19 Israeli, Palestinian benefits and costs, perceived benefits and costs, and gain ratios for Principle 3

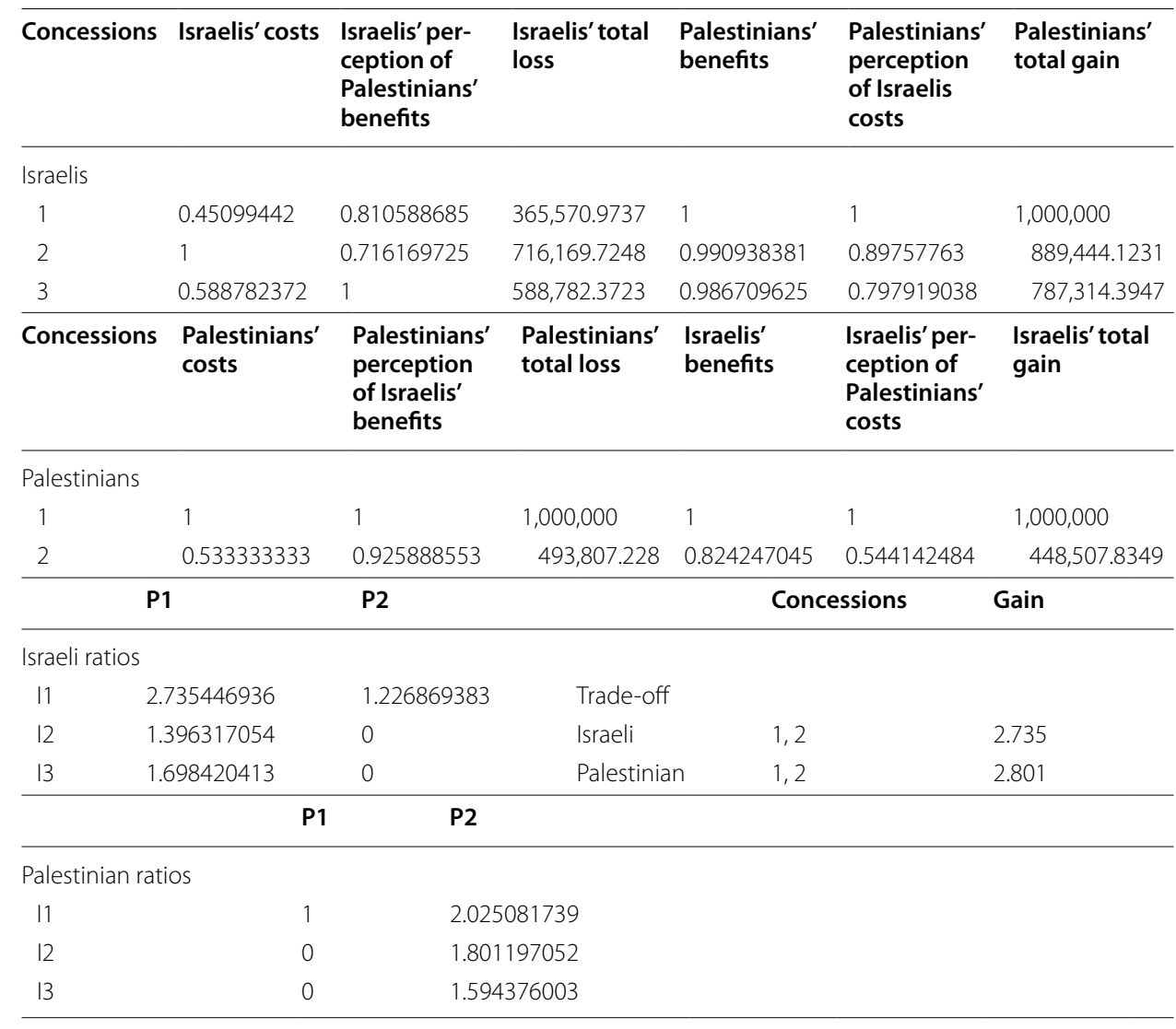

Note that the Israeli bundle consisting of the pairs $(I 1, P 1)$ and $(12, P 2)$ yielding a gain of 2.735 is matched with the Palestinian bundle consisting of the pairs (I1, P1) and (I2, P2) yielding a gain of 2.801 , which is within $2.5 \%$ of each other, which is an acceptable ratio. Please note that the Israeli and Palestinian actions are listed in Tables 17 and 18, respectively

3. Erosion of national ethos.

4. Puts a large strain on the Israeli democratic character.

\section{Palestinian actions}

1. Allowing Israel to choose between incremental and rapid removal of settlers/settlements.

2. A Palestinian commitment to fully collaborate with Israel during the relocation process and maintain a restrained approach toward the actual relocation.

3. Acknowledging the value of infrastructure, residential and commercial buildings and facilities, after Israeli withdraw.

\section{Palestinian perspective}

Benefits

1. Repossession of land and natural resources.

2. Eliminate the harassment by the settlers.

3. Ability to develop the Palestinian agriculture and urban development.

4. Security (feel more secure in the absence of settlers). 
5. Psychological and social benefits.

6. Ensuring geographic and integral contiguity.

Costs

1. Repair the damage caused by the settlers during evacuation.

2. Rehabilitation of the land and the facilities.

\section{Israeli Actions}

1. Ensure that the infrastructure is preserved.

2. Facilitate the evacuation without causing any damage to the properties or land.

3. Secure the evacuation process in regard to the Palestinian population.

Table 20 Israeli benefits, costs, perceived benefits and perceived costs for Principle 5

\begin{tabular}{|c|c|c|c|c|c|}
\hline Israeli benefits from Palestinian concessions & Priorities & \multicolumn{2}{|l|}{ P1 } & P2 & P3 \\
\hline Security benefits & 0.0461 & \multicolumn{2}{|l|}{0.825} & 0.788 & 0.725 \\
\hline Social and Economic benefits & 0.109 & \multicolumn{2}{|l|}{0.788} & 0.275 & 0.115 \\
\hline Increase in the effectiveness of military and police forces & 0.0585 & \multicolumn{2}{|l|}{0.588} & 0.825 & 0.078 \\
\hline Allow Israel to define its borders & 0.2023 & \multicolumn{2}{|l|}{0.313} & 0.4 & 0.078 \\
\hline Increased international support & 0.1837 & \multicolumn{2}{|l|}{0.213} & 0.788 & 0.033 \\
\hline \multirow[t]{2}{*}{ Strengthen the democratic nature of the state of Israel } & \multirow[t]{2}{*}{0.4004} & \multicolumn{2}{|l|}{0.563} & 0.563 & 0.01 \\
\hline & & \multicolumn{2}{|c|}{0.4858} & 0.5653 & 0.0762 \\
\hline Israeli costs from Israeli concessions & Priorities & \multicolumn{2}{|l|}{11} & 12 & 13 \\
\hline Economic cost to relocate the settlers & 0.1282 & \multicolumn{2}{|l|}{0.563} & 0.563 & 0.275 \\
\hline Rift in the Israeli society, danger of civil war/Jewish terror & 0.5261 & \multicolumn{2}{|l|}{0.5} & 0.5 & 0.75 \\
\hline Erosion of national ethos & 0.1208 & 0.788 & & .6 & 0.4 \\
\hline Puts a large strain on the Israeli democratic character & 0.2248 & 0.275 & & .5 & 0.5 \\
\hline & & 0.492 & & .5201 & 0.5906 \\
\hline Israeli perception of Palestinian benefits from Israeli cc & essions & Priorities & 11 & 12 & 13 \\
\hline Repossession of land and natural resources & & 0.3167 & 0.862 & 0.725 & 0.563 \\
\hline Eliminate the harassment by the settlers & & 0.0775 & 0.75 & 0.5 & 0.888 \\
\hline Ability to develop the Palestinian agriculture and urban de & pment & 0.15 & 0.85 & 0.725 & 0.438 \\
\hline Security (feel more secure in the absence of settlers) & & 0.1171 & 0.463 & 0.95 & 0.863 \\
\hline Psychological and social benefits & & 0.0909 & 0.625 & 0.725 & 0.825 \\
\hline Ensuring geographic and integral contiguity & & 0.2478 & 0.175 & 0.01 & 0.055 \\
\hline & & & 0.6131 & 0.5567 & 0.5021 \\
\hline Israeli perception of Palestinian costs from Palestinian & cessions & Priorities & P1 & P2 & P3 \\
\hline Repair the damage caused by the settlers during evacuatio & & 0.5074 & 0.193 & 0.825 & 0.115 \\
\hline Rehabilitation of the land and the facilities & & 0.4926 & 0.3 & 0.788 & 0.4 \\
\hline & & & 0.2455 & 0.8065 & 0.2554 \\
\hline
\end{tabular}

\section{Palestinian actions}

P1. Allowing Israeli to choose between incremental and rapid removal of settlers/settlements

P2. A Palestinian commitment to fully collaborate with Israeli during the relocation process and maintaining a restrained approach toward the actual relocation

P3. Acknowledging the value of infrastructure, residential and commercial buildings and facilities, after Israeli withdrawal 
Table 21 Palestinian benefits, costs, perceived benefits and perceived costs for Principle 5

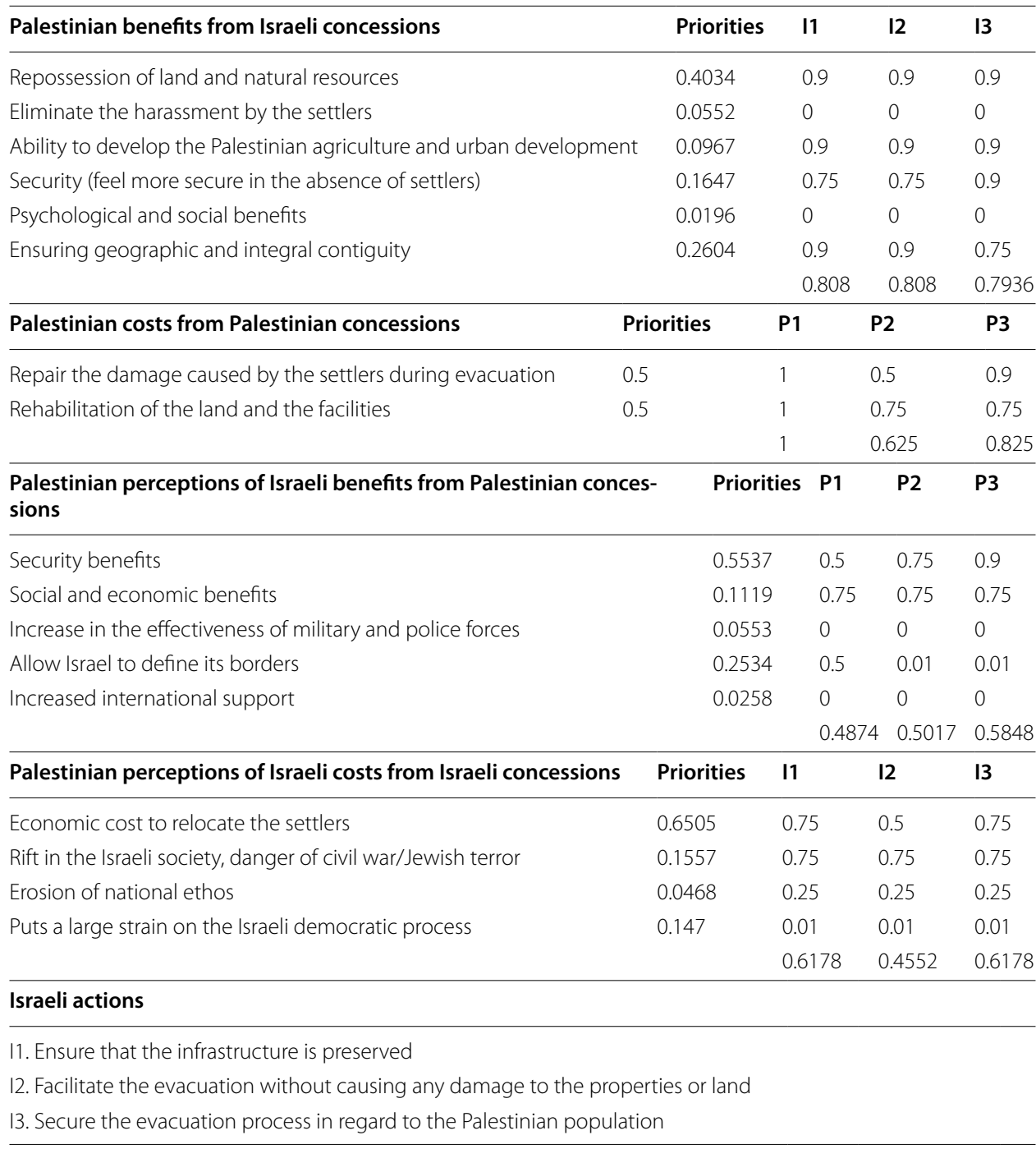

As a result of these matched concessions the actions to be required of each party will be as follows:

\section{Israeli actions}

- I2. Facilitate the evacuation without causing any damage to the properties or land.

\section{Palestinian actions}

- P2. A Palestinian commitment to fully collaborate with Israel during the relocation process and maintaining a restrained approach toward the actual relocation.

Principle 6 Palestinian full control of the borders of the Palestinian State and its outlets, and deployment of a temporary agreed upon multinational military monitoring system in the Jordan Valley (see Tables 23, 24 and 25). 
Table 22 Israeli, Palestinian benefits and costs, perceived benefits and costs, and gain ratios for Principle 5

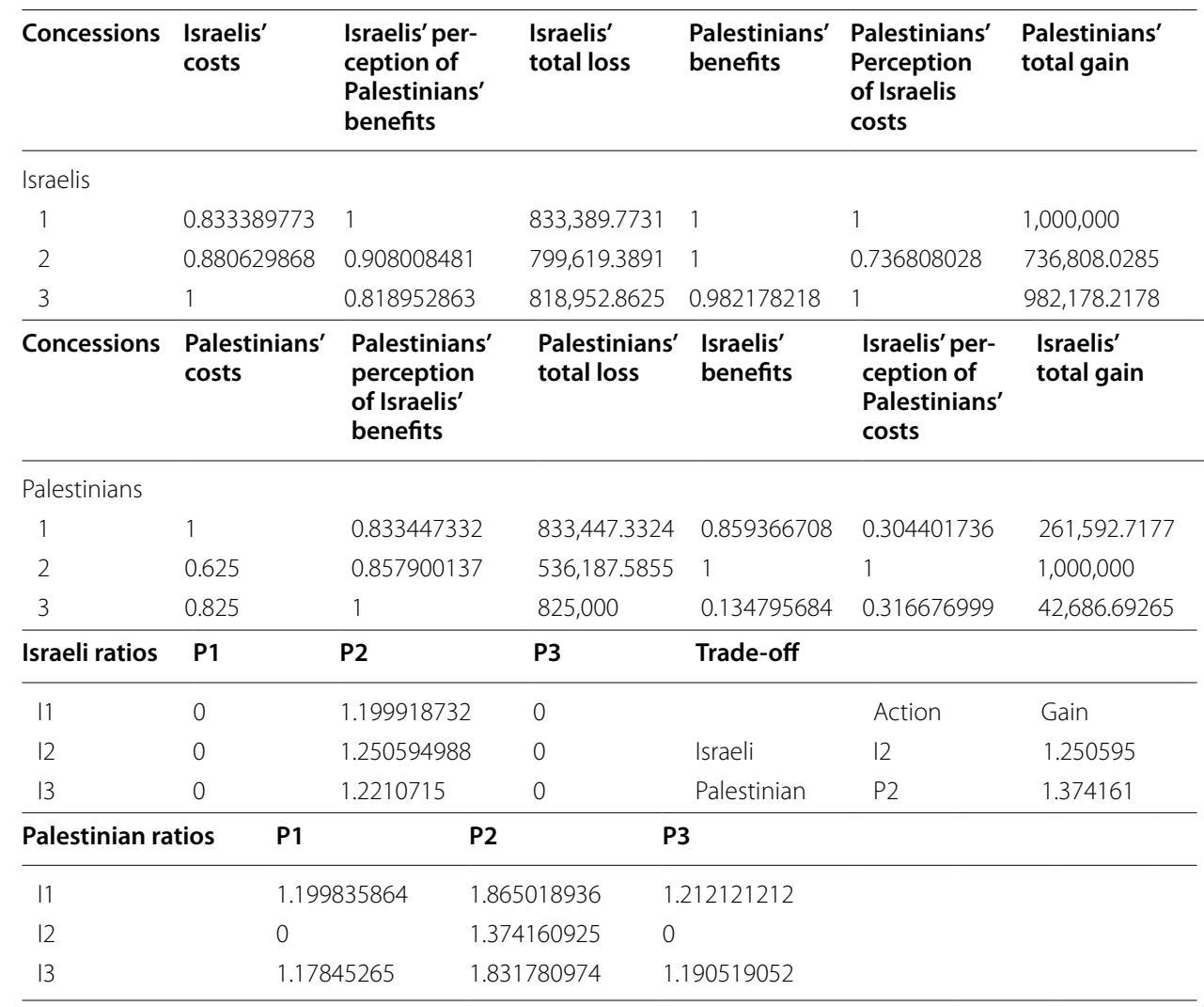

\section{Israeli perspective}

Benefits

1. Economic gains from relinquishing control of the borders (typically realized in term of operational costs) (see Tables 23, 24 and 25).

2. International benefits.

a. Improved international relationship.

b. Removal of sanctions.

3. Removal of sanctions.

4. Tourism.

5. Trade.

6. Increased security cooperation.

Costs

1. Security threat.
a. Palestine itself.
b. Internal actors such as Hamas.
c. Non-state actors.
d. Third party actors.

2. Loss of control.

3. Movement.

4. Maintenance of borders. 
5. Cooperation costs.

6. Political.

\section{Palestinian actions}

1. Palestinian control over customs.

2. Limited arms-Principle 8.

3. Multi-national oversight-Principle 9.

4. Access to airspace for training.

5. Maintain borders with other countries.

\section{Palestinian perspective}

Benefits

1. Economic gains internally and from controlling the borders: customs, relationships with neighboring countries.

2. International benefits: Open and establish international relationships and cooperation with the world.

3. Creating a new positive climate for better relations and cooperation between the two parties.

4. Free movement of people and goods.

5. Development of tourism industry.

6. Trade: controlling import and export on the basis of mutual benefits.

7. Political stability.

8. Encouraging international investment.

\section{Costs}

1. Running the border stations.

2. Manpower.

3. Political costs of engaging in early stages of the new situation with the Israelis.

\section{Israeli actions}

1. Total withdrawal from Palestinian territories.

2. Hand over fully the control point, border stations.

3. Provide Palestinians with all the information about the borders and passages.

4. Ensure no intervention what so ever in the border control points-respect the independence and integrity of the Palestinian borders.

5. Any information or requests passed through official channels on Palestinian side.

As a result of these matched concessions the actions to be required of each party will be as follows:

\begin{tabular}{|c|c|c|c|}
\hline Israeli actions & Gain & Palestinian actions & Gain \\
\hline 12. Hand over fully the control point, border stations & 1.4851 & P3. Multi-national oversight: Principle 9 & 1.5348 \\
\hline $\begin{array}{l}\text { 11. Total withdrawal from Palestinian territories } \\
\text { 15. Any information or requests passed through official } \\
\text { channels on Palestinian side }\end{array}$ & 1.2698 & $\begin{array}{l}\text { P2. Limited Arms: Principle } 8 \\
\text { P4. Access to airspace for training }\end{array}$ & 1.2103 \\
\hline
\end{tabular}

Principle 7 Solve the Palestinian refugee problem in a just and agreed upon manner (see Tables 26, 27, 28 and 29). 
Table 23 Israeli benefits, costs, perceived benefits and perceived costs for Principle 6

\begin{tabular}{|c|c|c|c|c|c|c|c|c|c|c|}
\hline \multicolumn{2}{|c|}{ Israeli benefits from Palestinian concessions } & \multicolumn{2}{|c|}{ Priorities } & \multicolumn{2}{|l|}{ P1 } & \multicolumn{2}{|l|}{ P2 } & P3 & P4 & P5 \\
\hline \multicolumn{2}{|l|}{ Economic gains from relinquishing control } & \multicolumn{2}{|l|}{0.1275} & \multicolumn{2}{|l|}{0.42} & \multicolumn{2}{|l|}{0.6} & 0.53 & 0.01 & 0.32 \\
\hline \multicolumn{2}{|l|}{ Improved international relationships } & \multicolumn{2}{|l|}{0.302} & \multicolumn{2}{|l|}{0.65} & \multicolumn{2}{|c|}{0.57} & 0.6 & 0.028 & 0.81 \\
\hline \multicolumn{2}{|l|}{ Removal of sanctions } & \multicolumn{2}{|l|}{0.0669} & \multicolumn{2}{|l|}{0.73} & \multicolumn{2}{|c|}{0.29} & 0.47 & 0.01 & 0.73 \\
\hline \multicolumn{2}{|l|}{ Tourism } & \multicolumn{2}{|l|}{0.1499} & \multicolumn{2}{|l|}{0.402} & \multicolumn{2}{|c|}{0.242} & 0.47 & 0.01 & 0.63 \\
\hline \multicolumn{2}{|l|}{ Trade } & \multicolumn{2}{|l|}{0.1591} & \multicolumn{2}{|l|}{0.55} & 0.01 & & 0.112 & 0.01 & 0.27 \\
\hline Increased security cooperation & & 0.1946 & & 0.55 & & 0.98 & & 0.87 & 0.47 & 0.55 \\
\hline & & & & 0.553 & & 0.49 & 966 & 0.5378 & 0.105 & 0.5787 \\
\hline Israeli costs from Israeli concessions & Prior & ties & $\mathbf{I 1}$ & & 12 & & 13 & 14 & & 15 \\
\hline Security threat & 0.511 & & 0.84 & & 0.5 & & 0.222 & 2 & .6 & 0.082 \\
\hline Loss of control & 0.310 & & 0.81 & & 0.75 & & 0.22 & 0 . & .7 & 0.16 \\
\hline Maintenance of borders & 0.092 & & 0.56 & & 0.45 & & 0.18 & & .55 & 0.1 \\
\hline Cooperation costs & 0.085 & & 0.58 & & 0.86 & & 0.71 & & .58 & 0.53 \\
\hline & & & 0.782 & & 0.603 & & 0.259 & 94 & 6247 & 0.1463 \\
\hline $\begin{array}{l}\text { Israeli perception of Palestinian benefi } \\
\text { concessions }\end{array}$ & from & sraeli & Prio & rities & 11 & & 12 & 13 & 14 & 15 \\
\hline $\begin{array}{l}\text { Economic gains internally and from contr } \\
\text { borders: FDI, customs, relationships with } \\
\text { countries }\end{array}$ & $\begin{array}{l}\text { lling th } \\
\text { neight }\end{array}$ & pring & 0.166 & & 0.65 & & 0.4 & 0.19 & 0.5 & 0.24 \\
\hline $\begin{array}{l}\text { International benefits: open and establish } \\
\text { relationships and cooperation with the }\end{array}$ & $\begin{array}{l}\text { nterna } \\
\text { Jorld }\end{array}$ & onal & 0.142 & & 0.81 & & 0.55 & 0.32 & 0.24 & 0.16 \\
\hline $\begin{array}{l}\text { Creating a new positive climate for better } \\
\text { cooperation between the two parties }\end{array}$ & elation & and & 0.23 & & 1 & & 0.73 & 0.65 & 0.89 & 0.9 \\
\hline Free movement of people and goods & & & 0.246 & & 1 & & 0.96 & 0.45 & 0.222 & 0.472 \\
\hline Development of tourism industry & & & 0.075 & & 0.4 & & 0.81 & 0.32 & 0.29 & 0.224 \\
\hline Political stability & & & 0.13 & & 0.93 & & 0.6 & 0.16 & 0.65 & 0.046 \\
\hline & & & & & 0.85 & 574 & 0.6953 & 0.3861 & 0.4883 & 0.4126 \\
\hline $\begin{array}{l}\text { Israeli perception of Palestinian costs } \mathrm{f} \\
\text { concessions }\end{array}$ & om Pa & stinian & Prio & rities & P1 & & P2 & P3 & P4 & P5 \\
\hline Running the border stations & & & 0.55 & & 0.55 & & 0.55 & 0.84 & 0.082 & 0.89 \\
\hline Political Costs of engaging in early stages & f the $n$ & w situ- & 0.445 & & 0.27 & 72 & 0.7 & 0.45 & 0.84 & 0.29 \\
\hline & & & & & 0.42 & 262 & 0.6168 & 30.6663 & 0.4195 & 0.6228 \\
\hline Palestinian actions & & & & & & & & & & \\
\hline P1. Palestinian control over customs & & & & & & & & & & \\
\hline P2. Limited Arms: Principle 8 & & & & & & & & & & \\
\hline P3. Multi-national oversight: Principle 9 & & & & & & & & & & \\
\hline P4. Access to airspace for training & & & & & & & & & & \\
\hline P5. Maintain borders with other countries & & & & & & & & & & \\
\hline
\end{tabular}

\section{Israeli perspective}

Benefits

1. Preservation of the Jewish and democratic nature of Israel.

2. Compensation for Jews from Arab lands/recognition as refugees (in accordance with Israeli law requiring this issue be raised in context of I-P negotiations).

3. Starting reconciliation process with the Palestinian people.

4. International recognition of the finality of the refugee problems. 
Table 24 Palestinian benefits, costs, perceived benefits and perceived costs for Principle 6

\begin{tabular}{|c|c|c|c|c|c|c|}
\hline Palestinian benefits from Israeli concessions & Priorities & 11 & 12 & 13 & 14 & 15 \\
\hline $\begin{array}{l}\text { Economic gains internally and from controlling the bor- } \\
\text { ders: customs, relationships with neighboring countries }\end{array}$ & 0.3076 & 1 & 1 & 0.91 & 0.98 & 0.87 \\
\hline $\begin{array}{l}\text { International benefits: Open and establish international } \\
\text { relationships and cooperation with the world }\end{array}$ & 0.0875 & 1 & 1 & 0.9 & 0.98 & 0.84 \\
\hline $\begin{array}{l}\text { Creating a new positive climate for better relations and } \\
\text { cooperation between the two parties }\end{array}$ & 0.0403 & 0.94 & 0.98 & 0.9 & 0.98 & 0.86 \\
\hline Free movement of people and goods & 0.2912 & 0.98 & 0.98 & 0.37 & 0.82 & 0.16 \\
\hline Development of tourism industry & 0.0484 & 0.94 & 0.84 & 0.6 & 0.83 & 0.4 \\
\hline $\begin{array}{l}\text { Trade: Controlling import and export on the basis of } \\
\text { mutual benefits }\end{array}$ & 0.0817 & 1 & 0.92 & 0.81 & 0.79 & 0.45 \\
\hline Political stability & 0.119 & 1 & 0.93 & 0.71 & 0.91 & 0.84 \\
\hline \multirow[t]{2}{*}{ Encouraging international investment } & 0.0243 & 0.95 & 0.88 & 0.76 & 0.78 & 0.66 \\
\hline & & 0.9876 & 0.9679 & 0.7009 & 0.8974 & 0.5945 \\
\hline Palestinian costs from Palestinian concessions & Priorities & P1 & P2 & P3 & P4 & P5 \\
\hline Running the border stations & 0.5516 & 0.87 & 0.84 & 0.7 & 0.95 & 0.81 \\
\hline Manpower & 0.2858 & 0.76 & 0.66 & 0.65 & 0.95 & 0.76 \\
\hline \multirow{2}{*}{$\begin{array}{l}\text { Political costs of engaging in early stages of the new situa- } \\
\text { tion with the Israelis }\end{array}$} & 0.1627 & 0.35 & 0.76 & 0.73 & 0.88 & 0.73 \\
\hline & & 0.754 & 0.7755 & 0.6906 & 0.9386 & 0.7827 \\
\hline $\begin{array}{l}\text { Palestinian perceptions of Israeli benefits from Pales- } \\
\text { tinian concessions }\end{array}$ & Priorities & P1 & P2 & P3 & P4 & P5 \\
\hline Economic gains from relinquishing control & 0.2237 & 1 & 0.9 & 0.25 & 0.75 & 0.25 \\
\hline Improved international relationships & 0.1759 & 0.75 & 0.9 & 0.9 & 0.5 & 0.9 \\
\hline Removal of sanctions & 0.0107 & 0 & 0 & 0 & 0 & 0 \\
\hline Movement & 0.0241 & 0 & 0 & 0 & 0 & 0 \\
\hline Tourism & 0.0542 & 0 & 0 & 0 & 0 & 0 \\
\hline Trade & 0.1923 & 0.1 & 0.75 & 0.75 & 1 & 0.1 \\
\hline Cooperation & 0.0167 & 0 & 0 & 0 & 0 & 0 \\
\hline \multirow[t]{2}{*}{ Political } & 0.3025 & 0.1 & 0.9 & 0.9 & 1 & 0.1 \\
\hline & & 0.4051 & 0.776 & 0.6306 & 0.7505 & 0.2637 \\
\hline $\begin{array}{l}\text { Palestinian perceptions of Israeli costs from Israeli } \\
\text { concessions }\end{array}$ & Priorities & 11 & 12 & 13 & 14 & 15 \\
\hline Threat & 0.0254 & 0 & 0 & 0 & 0 & 0 \\
\hline Loss of control & 0.2777 & 0.25 & 0.5 & 0.5 & 0.25 & 0.25 \\
\hline Movement & 0.0748 & 0 & 0 & 0 & 0 & 0 \\
\hline Maintenance of borders & 0.4573 & 1 & 0.75 & 0.75 & 0.01 & 0.5 \\
\hline Cooperation costs & 0.0397 & 0 & 0 & 0 & 0 & 0 \\
\hline \multirow[t]{2}{*}{ Political } & 0.1251 & 0.01 & 0.1 & 0.1 & 0.25 & 0.1 \\
\hline & & 0.5279 & 0.4943 & 0.4943 & 0.1053 & 0.3106 \\
\hline
\end{tabular}

Israeli actions

11. Total withdrawal from Palestinian territories

12. Hand over fully the control point, border stations

13. Provide Palestinians with all the information about the borders and passages

14. Ensure no intervention what so ever in the border control points: respect the independence and integrity of the Palestinian borders

15. Any information or requests passed through official channels on Palestinian side 
Table 25 Israeli, Palestinian benefits and costs, perceived benefits and costs, and Gain Ratios for Principle 6

\begin{tabular}{|c|c|c|c|c|c|c|c|c|c|c|c|}
\hline Concessions & \multicolumn{2}{|c|}{ Israelis' costs } & \multicolumn{2}{|c|}{$\begin{array}{l}\text { Israelis' per- } \\
\text { ception of } \\
\text { Palestinians' } \\
\text { benefits }\end{array}$} & \multicolumn{2}{|c|}{$\begin{array}{l}\text { Israelis' total } \\
\text { loss }\end{array}$} & \multicolumn{2}{|c|}{$\begin{array}{l}\text { Palestinians' } \\
\text { benefits }\end{array}$} & \multicolumn{2}{|c|}{$\begin{array}{l}\text { Palestinians' } \\
\text { perception } \\
\text { of Israelis } \\
\text { costs }\end{array}$} & $\begin{array}{l}\text { Palestinians' } \\
\text { total gain }\end{array}$ \\
\hline \multicolumn{12}{|l|}{ Israelis } \\
\hline 11 & \multicolumn{2}{|l|}{1} & \multicolumn{2}{|l|}{1} & \multicolumn{2}{|c|}{$1,000,000$} & \multicolumn{2}{|l|}{1} & \multicolumn{2}{|l|}{1} & $1,000,000$ \\
\hline 12 & \multicolumn{2}{|c|}{0.771658574} & \multicolumn{2}{|c|}{0.810940051} & \multicolumn{2}{|c|}{$625,768.8436$} & \multicolumn{2}{|c|}{0.980052653} & \multicolumn{2}{|c|}{0.936351582} & $917,673.8517$ \\
\hline 13 & \multicolumn{2}{|c|}{0.331459238} & \multicolumn{2}{|c|}{0.450314906} & \multicolumn{2}{|c|}{$149,261.0356$} & \multicolumn{2}{|c|}{0.709700284} & \multicolumn{2}{|c|}{0.936351582} & $664,528.983$ \\
\hline 14 & \multicolumn{2}{|c|}{0.798236647} & \multicolumn{2}{|c|}{0.56951248} & \multicolumn{2}{|c|}{$454,605.7322$} & \multicolumn{2}{|c|}{0.908667477} & 0.19946 & 9597 & $181,251.5349$ \\
\hline 15 & 0.1869 & 940966 & 0.4812 & 223 & 89,960 & 0.16162 & 0.6019 & 64358 & 0.58836 & 9009 & $354,177.173$ \\
\hline Concessions & $\begin{array}{l}\text { Pales } \\
\text { costs }\end{array}$ & tinians' & $\begin{array}{l}\text { Pales } \\
\text { perc } \\
\text { of Isr } \\
\text { bene }\end{array}$ & $\begin{array}{l}\text { tinians' } \\
\text { eption } \\
\text { aelis' } \\
\text { fits }\end{array}$ & $\begin{array}{l}\text { Pales } \\
\text { total }\end{array}$ & $\begin{array}{l}\text { stinians' } \\
\text { loss }\end{array}$ & $\begin{array}{l}\text { Israeli } \\
\text { benef }\end{array}$ & & $\begin{array}{l}\text { Israelis' } \\
\text { ception } \\
\text { Palestir } \\
\text { costs }\end{array}$ & $\begin{array}{l}\text { per- } \\
\text { of } \\
\text { ians' }\end{array}$ & $\begin{array}{l}\text { Israelis' total } \\
\text { gain }\end{array}$ \\
\hline Palestinians & & & & & & & & & & & \\
\hline $\mathrm{PI}$ & 0.803 & 3241 & 0.522 & 036082 & 419,3 & 364.166 & 0.9564 & 54121 & 0.63965 & 1808 & $611,797.6084$ \\
\hline P2 & 0.826 & 230556 & 1 & & 826,2 & 30.5561 & 0.8581 & 30292 & 0.92570 & 914 & $794,379.0547$ \\
\hline P3 & 0.735 & 776689 & 0.812 & 628866 & 597,9 & 13.3761 & 0.9293 & 24348 & 1 & & $929,324.3477$ \\
\hline P4 & 1 & & 0.967 & 139175 & 967,1 & 39.1753 & 0.1814 & 41161 & 0.62959 & 5278 & $114,234.6798$ \\
\hline P5 & 0.833 & 901556 & 0.339 & 819588 & 283,3 & 776.0827 & 1 & & 0.93471 & 4093 & $934,714.0928$ \\
\hline Israeli ratios & $\mathrm{PI}$ & & & 2 & & P3 & & P4 & & P5 & \\
\hline 11 & 0 & & 0 & & & 0 & & 0 & & 0 & \\
\hline 12 & 0 & & & .26944488 & & 1.485092 & 071 & 0 & & 1.493 & 705068 \\
\hline 13 & & 98843384 & & .32207921 & & 6.226168 & 428 & 0 & & 6.262 & 277953 \\
\hline 14 & & 345776274 & & .74740219 & & 2.044242 & 476 & 0 & & 2.056 & 098343 \\
\hline 15 & & 300761553 & & .83034268 & & 10.33039 & 882 & 1.2698 & 36311 & 10.39 & 03114 \\
\hline Palestinian ra & tios & PI & & P2 & & P3 & & P4 & & P5 & \\
\hline 11 & & 2.38456 & 52347 & 1.21031 & 15925 & 1.6724 & 483072 & 1.03 & 3977348 & $3.52 \varepsilon$ & 8879327 \\
\hline 12 & & 2.18825 & 50514 & 1.11067 & 75277 & 1.5347 & 793982 & 0 & & 3.238 & 8360284 \\
\hline 13 & & 1.58461 & 0792 & 0 & & 1.1114 & +13475 & 0 & & 2.34 & 504259 \\
\hline 14 & & 0 & & 0 & & 0 & & 0 & & 0 & \\
\hline 15 & & 0 & & 0 & & 0 & & 0 & & $1.24 \varsigma$ & 9848504 \\
\hline & & Action & & Gain & & & & & & & \\
\hline Trade-off & & & & & & & & & & & \\
\hline Israeli & & 12 & & 1.48509 & 92071 & & & & & & \\
\hline Palestinian & & P3 & & 1.53479 & 93982 & & & & & & \\
\hline Israeli & & 15 & & 1.26983 & 36311 & & & & & & \\
\hline Palestinian & & P4 & & 0 & & & & & & & \\
\hline Israeli & & 11 & & 0 & & & & & & & \\
\hline Palestinian & & $\mathrm{P} 2$ & & 1.21031 & 15925 & & & & & & \\
\hline
\end{tabular}

Costs

1. Destroying the Jewish democratic nature of the State of Israel.

2. Destruction of towns and villages of Israel and resettlement of millions of Israelis.

3. Creating new imminent friction between Israelis and Palestinians.

4. Political. 
5. To remain open to Palestinian claims.

6. Israel taking responsibility for the creation of the Palestinian refugee issue will leave Israel solely responsible for solving the refugee issue financially and morally.

\section{Palestinian actions}

1. Recognition of Israel as the nation state of the Jewish people.

2. Acknowledging the right of Palestinian refugees to return exclusively to the State of Palestine.

3. Resolution of the Palestinian refugee issue will settle all claims, collective and individual, of the Palestinian refugees.

4. The State of Israel has the exclusive right to decide who returns or immigrates to the State of Israel.

5. Claims for compensation of Palestinian refugees will be exclusively resolved by an agreed upon international mechanism with the participation and contribution of Israel.

6. Israel's contribution as defined by the agreement between the parties will be the total and final compensation to all claims.

7. Within 5 years of the establishment of the international mechanism, UNRWA will dissolve and refugee status will be formally annulled.

8. Palestinians will commit to a reconciliation process, conducted by a joint committee.

9. Jewish refugees shall be compensated.

10. This agreement provides for the permanent and complete resolution of the Palestinian refugee issue.

\section{Palestinian perspective}

Benefits

1. Israeli acknowledgement of its responsibility for the Palestinian refugee problem.

2. End of suffering of the Palestinian people.

3. End of conflict.

4. Protecting, maintaining and enhancing the Palestinian social fabric.

5. Returning Palestinian control over their destiny.

6. Enabling the Palestinian people to have its share of regional development projects.

7. Rehabilitating and integrating the refugees into the Palestinian society and elsewhere.

8. Peace and stability in the region.

9. Contributing to the welfare of the host countries.

10. Create a climate of mutual cooperation and normalization with Israel.

Costs

1. Failure to resolve the refugee problem.

2. Undermining any other option for resolving the refugee problem.

3. Palestinian refugees considered as immigrants to Israel and not as people who have the right of return.

4. Denial of the Palestinian right to participate in the decision making for resolving the refugee problem. 
Table 26 Israeli benefits, costs, perceived benefits and perceived costs for Principle 7

\begin{tabular}{|c|c|c|c|c|c|c|c|c|c|c|c|}
\hline $\begin{array}{l}\text { Israeli benefits } \\
\text { from Palestin- } \\
\text { ian concessions }\end{array}$ & Priorities & $s$ P1 & P2 & P3 & P4 & P5 & P6 & P7 & P8 & P9 & P10 \\
\hline $\begin{array}{l}\text { Preservation of } \\
\text { the Jewish and } \\
\text { democratic } \\
\text { nature of Israel }\end{array}$ & 0.6723 & 0.788 & 1 & 1 & 1 & 0.113 & 0.575 & 0.538 & 0.525 & 0.363 & 0.975 \\
\hline $\begin{array}{l}\text { Compensation } \\
\text { for Jews from } \\
\text { Arab lands/ } \\
\text { recognition as } \\
\text { refugees }\end{array}$ & 0.0494 & 0.088 & 0.1120. & 0.438 & 0.025 & 0.463 & 0.275 & 0.213 & 0.3 & 1 & 0.175 \\
\hline $\begin{array}{l}\text { Starting } \\
\text { reconciliation } \\
\text { process with } \\
\text { the Palestinian } \\
\text { people }\end{array}$ & 0.0853 & 0.625 & 0.3130. & 0.763 & 0.538 & 0.663 & 0.563 & 0.862 & 1 & 0.862 & 0.862 \\
\hline \multirow{2}{*}{$\begin{array}{l}\text { International } \\
\text { recognition of } \\
\text { the finality of } \\
\text { the refugee } \\
\text { problems }\end{array}$} & 0.1929 & 0.5 & 0.9250. & 0.975 & 0.763 & 0.888 & 0.9 & 0.975 & 0.888 & 0.6 & 0.925 \\
\hline & & 0.68360 & $0.883 \quad 0$. & $0.9471 \quad 0$ & 0.8665 & 0.32630 & 0.6218 & 0.6336 & 0.6244 & 0.4825 & 0.9162 \\
\hline \multicolumn{2}{|c|}{$\begin{array}{l}\text { Israeli costs from Israeli } \\
\text { concessions }\end{array}$} & Priorities & 11 & 12 & 13 & 14 & 15 & 16 & & & \\
\hline \multicolumn{2}{|c|}{$\begin{array}{l}\text { Destroying the Jewish } \\
\text { democratic nature of } \\
\text { the State of Israel }\end{array}$} & 0.3833 & 1 & 0.112 & 0 & 0.8 & 0.075 & 0.275 & & & \\
\hline \multicolumn{2}{|c|}{$\begin{array}{l}\text { Destruction of towns and } \\
\text { villages of Israel and } \\
\text { resettlement of millions } \\
\text { of Israelis }\end{array}$} & 0.3289 & 0.975 & 0.025 & 0.088 & 0.913 & 0.088 & 0.213 & & & \\
\hline \multicolumn{2}{|c|}{$\begin{array}{l}\text { Creating new imminent } \\
\text { friction between Israelis } \\
\text { and Palestinians }\end{array}$} & 0.0631 & 0.975 & 0.075 & 0.188 & 0.538 & 0.112 & 0.313 & & & \\
\hline \multicolumn{2}{|c|}{ Political } & 0.037 & 0.925 & 0.112 & 0.112 & 0.925 & 0.15 & 0.088 & & & \\
\hline \multicolumn{2}{|c|}{$\begin{array}{l}\text { To remain open to Pales- } \\
\text { tinian claims }\end{array}$} & 0.1179 & 0.338 & 0.625 & 0.5 & 0.888 & 0.075 & 0.25 & & & \\
\hline \multirow{2}{*}{\multicolumn{2}{|c|}{$\begin{array}{l}\text { Israel taking responsibility } \\
\text { for the creation of the } \\
\text { Palestinian refugee issue }\end{array}$}} & 0.0698 & 0.925 & 0.625 & 0.215 & 0.763 & 0.153 & 0.34 & & & \\
\hline & & & 0.9041 & 0.1776 & $5 \quad 0.1187$ & $7 \quad 0.8328$ & 30.0897 & $7 \quad 0.2515$ & & & \\
\hline \multicolumn{2}{|c|}{$\begin{array}{l}\text { Israeli perceived Palestin- } \\
\text { ian benefits from Israeli } \\
\text { concessions }\end{array}$} & Priorities & es 11 & 12 & 13 & 14 & 15 & 16 & & & \\
\hline \multicolumn{2}{|c|}{$\begin{array}{l}\text { Israeli acknowledgement } \\
\text { of its responsibility for } \\
\text { the Palestinian refugee } \\
\text { problem }\end{array}$} & 0.1499 & 0.95 & 0.463 & 30.025 & 0.888 & 0.112 & 0.438 & & & \\
\hline \multicolumn{2}{|c|}{$\begin{array}{l}\text { End of suffering of the Pales- } \\
\text { tinian people }\end{array}$} & 0.2003 & 0.925 & 250.763 & 30.5 & 0.625 & 0.8 & 0.862 & & & \\
\hline \multicolumn{2}{|c|}{ End of conflict } & 0.066 & 0.9 & 0 & 0 & 0 & 0 & 0 & & & \\
\hline \multicolumn{2}{|c|}{$\begin{array}{l}\text { Protecting, maintaining and } \\
\text { enhancing the Palestinian } \\
\text { social fabric }\end{array}$} & 0.0803 & 0 & 0.563 & 30.663 & 0.763 & 0.788 & 0.4 & & & \\
\hline \multicolumn{2}{|c|}{$\begin{array}{l}\text { Retaining Palestinian control } \\
\text { over their destiny }\end{array}$} & 0.1627 & 0.463 & 530.6 & 0.663 & 0.888 & 0.688 & 0.5 & & & \\
\hline
\end{tabular}


Table 26 continued

\begin{tabular}{|c|c|c|c|c|c|c|c|c|c|c|c|}
\hline \multicolumn{2}{|c|}{$\begin{array}{l}\text { Israeli perceived Palestin- } \\
\text { ian benefits from Israeli } \\
\text { concessions }\end{array}$} & Priorities & 11 & 12 & 13 & 14 & 15 & 16 & & & \\
\hline \multicolumn{2}{|c|}{$\begin{array}{l}\text { Enabling the Palestinian } \\
\text { people to have its share } \\
\text { of regional development } \\
\text { projects }\end{array}$} & 0.0476 & 0 & 0 & 0 & 0 & 0 & 0 & & & \\
\hline \multicolumn{2}{|c|}{$\begin{array}{l}\text { Rehabilitating and integrat- } \\
\text { ing the refugees into the } \\
\text { Palestinian society and } \\
\text { elsewhere }\end{array}$} & 0.1439 & 0.275 & 0.9 & 0.7 & 0.8 & 0.9 & 0.788 & & & \\
\hline \multicolumn{2}{|c|}{$\begin{array}{l}\text { Peace and stability in the } \\
\text { region }\end{array}$} & 0.0446 & 0.663 & 0.663 & 0.825 & 0.7 & 0.825 & 0.663 & & & \\
\hline \multicolumn{2}{|c|}{$\begin{array}{l}\text { Contributing to the welfare } \\
\text { of the host countries }\end{array}$} & 0.0283 & 0 & 0 & 0 & 0 & 0 & 0 & & & \\
\hline \multirow{2}{*}{\multicolumn{2}{|c|}{$\begin{array}{l}\text { Create a climate of mutual } \\
\text { cooperation and normali- } \\
\text { zation with Israel }\end{array}$}} & 0.0764 & 0.4 & 0.8 & 0.75 & 0.7 & 0.825 & 0.538 & & & \\
\hline & & & 0.562 & 0.585 & 0.4597 & 0.6636 & 0.5815 & \multicolumn{2}{|c|}{0.5357} & & \\
\hline $\begin{array}{l}\text { Israeli Perceived } \\
\text { Palestinian costs } \\
\text { from Palestinian } \\
\text { Concessions }\end{array}$ & Priorities & P1 & P2 & P3 & P4 & P5 & P6 & P7 & P8 & P9 & P10 \\
\hline $\begin{array}{l}\text { Failure to resolve the } \\
\text { refugee problem }\end{array}$ & 0.287 & 0.8 & 0.425 & 0.15 & 0.862 & 0.625 & 0.625 & 0.725 & 0.25 & 0.313 & 0.763 \\
\hline $\begin{array}{l}\text { Undermining any } \\
\text { other option for } \\
\text { resolving the refu- } \\
\text { gee problem }\end{array}$ & 0.1173 & 0.862 & 0.95 & 0.075 & 0.1 & 0.025 & 0.338 & 0.4 & 0.025 & 0.125 & 0.5 \\
\hline $\begin{array}{l}\text { Palestinian refugees } \\
\text { considered as } \\
\text { immigrants to Israel } \\
\text { and not as people } \\
\text { who have the right } \\
\text { of return }\end{array}$ & 0.0315 & 0.825 & 0.725 & 0.1 & 0.088 & 0.05 & 0 & 0.088 & 0.05 & 0.025 & 0.338 \\
\hline $\begin{array}{l}\text { Denial of the } \\
\text { Palestinian right to } \\
\text { participate in the } \\
\text { decision making } \\
\text { for resolving the } \\
\text { refugee problem }\end{array}$ & 0.1092 & 0.825 & 0.85 & 0.563 & 0.9 & 0.238 & 0.275 & 0.275 & 0.05 & 0 & 0.075 \\
\hline $\begin{array}{l}\text { Dissolving UNRWA } \\
\text { before the final } \\
\text { resolution of the } \\
\text { refugee problem } \\
\text { and ending the sta- } \\
\text { tus of the refugees } \\
\text { as refugees }\end{array}$ & 0.0634 & 0.195 & 0.09 & 0.1 & 0.37 & 0.375 & 0.115 & 0.225 & 0.255 & 0 & 0.05 \\
\hline $\begin{array}{l}\text { Exacerbation of } \\
\text { the suffering of } \\
\text { the refugees as a } \\
\text { result of dissolving } \\
\text { UNRWA before the } \\
\text { final settlement of } \\
\text { the claims }\end{array}$ & 0.0668 & 0.065 & 0.5 & 0.05 & 0.338 & 0.24 & 0.155 & 0.625 & 0.05 & 0 & 0.025 \\
\hline \multirow{2}{*}{$\begin{array}{l}\text { Potential for not } \\
\text { implementing the } \\
\text { agreement }\end{array}$} & 0.3248 & 0.9 & 0.862 & 0.028 & 0.378 & 0.277 & 0.215 & 0.215 & 0.125 & 0.313 & 0.528 \\
\hline & & 0.75590 & 0.6683 & 0.1351 & 0.5289 & 0.3398 & 0.3365 & 0.4136 & 0.1418 & 0.2066 & 0.4725 \\
\hline
\end{tabular}


Table 27 Palestinian benefits, costs, perceived benefits and perceived costs for Principle 7

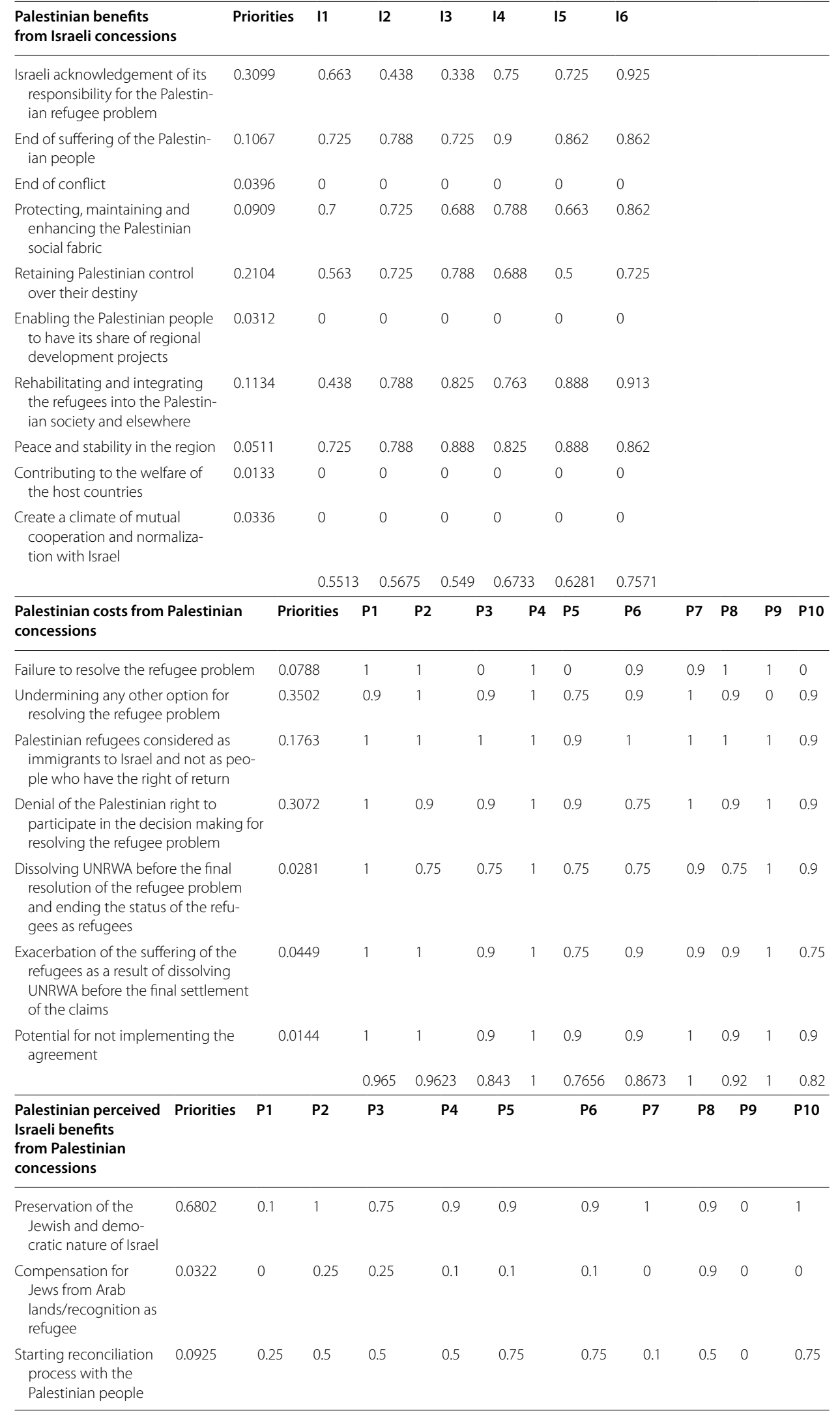


Table 27 continued

\begin{tabular}{|c|c|c|c|c|c|c|c|c|c|c|c|}
\hline $\begin{array}{l}\text { Palestinian perceived } \\
\text { Israeli benefits } \\
\text { from Palestinian } \\
\text { concessions }\end{array}$ & Priorities & P1 & P2 & P3 & P4 & P5 & P6 & P7 & P8 & P9 & P10 \\
\hline \multirow{2}{*}{$\begin{array}{l}\text { International recogni- } \\
\text { tion of the finality of } \\
\text { the refugee problem }\end{array}$} & 0.1951 & 0.25 & 0.25 & 0.75 & 0.75 & 0.9 & 0.9 & 0.5 & 0.9 & 0 & 0.75 \\
\hline & & 0.1399 & 0.7832 & 0.711 & 0.808 & 0.8603 & 0.8603 & 0.8 & 0.86 & 0 & 0.9 \\
\hline $\begin{array}{l}\text { Palestinian } \\
\text { perceived Israeli } \\
\text { costs from Israeli } \\
\text { concessions }\end{array}$ & Priorities & 11 & 12 & 13 & 14 & 15 & 16 & & & & \\
\hline $\begin{array}{l}\text { Destroying the } \\
\text { Jewish charac- } \\
\text { ter of the State } \\
\text { of Israel }\end{array}$ & 0.3498 & 0.75 & 0.25 & 0 & 0 & 0 & 0 & & & & \\
\hline $\begin{array}{l}\text { Destruction of } \\
\text { towns and } \\
\text { villages of Israel } \\
\text { and resettle- } \\
\text { ment of millions } \\
\text { of Israelis }\end{array}$ & 0.0324 & 0.75 & 0 & 0 & 0 & 0 & 0 & & & & \\
\hline $\begin{array}{l}\text { Creating new } \\
\text { imminent fric- } \\
\text { tion between } \\
\text { Israelis and } \\
\text { Palestinians }\end{array}$ & 0.0446 & 0.75 & 0.1 & 0 & 0.1 & 0 & 0 & & & & \\
\hline Political & 0.1433 & 0.9 & 0.1 & 0.1 & 0.5 & 0.25 & 0.75 & & & & \\
\hline $\begin{array}{l}\text { To remain open } \\
\text { to Palestinian } \\
\text { claims }\end{array}$ & 0.2069 & 0.9 & 0.5 & 0 & 0.25 & 0.75 & 0.1 & & & & \\
\hline \multirow{2}{*}{$\begin{array}{l}\text { Israel taking } \\
\text { responsibility for } \\
\text { the creation of } \\
\text { the Palestinian } \\
\text { refugee issue }\end{array}$} & 0.2229 & 0.9 & 0 & 0.5 & 0.75 & 0.25 & 0.1 & & & & \\
\hline & & 0.836 & 0.2097 & 0.126 & 0.295 & 0.2467 & 0.1505 & & & & \\
\hline
\end{tabular}

5. Dissolving UNRWA before the final resolution of the refugee problem and ending the status of the refugees as refugees.

6. Exacerbation of the suffering of the refugees as a result of dissolving UNRWA before the final settlement of the claims.

7. Potential for not implementing the agreement.

\section{Israeli actions}

1. Right to choose to return to their original home.

2. Right to choose to resettle in the State of Palestine, the host countries or third countries.

3. Endorsement of the international community.

4. Endorsement of the Palestinian refugees comprehensive and individual justice.

5. International commission to develop opportunities for the refugees.

6. International commission to adjudicate property claims. 
Table 28 Israeli, Palestinian benefits and costs, perceived benefits and costs for Principle 7

\begin{tabular}{lllllll}
\hline Concessions & Israelis' costs & $\begin{array}{l}\text { Israelis' per- } \\
\text { ception of } \\
\text { Palestinians' } \\
\text { benefits }\end{array}$ & $\begin{array}{l}\text { Israelis' total } \\
\text { loss }\end{array}$ & $\begin{array}{l}\text { Palestinians' } \\
\text { benefits }\end{array}$ & $\begin{array}{l}\text { Palestinians' } \\
\text { perception } \\
\text { of Israelis } \\
\text { costs }\end{array}$ & $\begin{array}{l}\text { Palestinians' } \\
\text { total gain }\end{array}$ \\
\hline Israelis & & & & & \\
I1 & 1 & 0.84689572 & $846,895.7203$ & 0.728173293 & 1 & $728,173.2928$ \\
I2 & 0.196438447 & 0.881555154 & $173,171.3254$ & 0.74957073 & 0.250837321 & $188,020.3136$ \\
I3 & 0.131290786 & 0.692736588 & $90,949.93146$ & 0.725135385 & 0.150478469 & $109,117.2625$ \\
I4 & 0.921137042 & 1 & $921,137.0424$ & 0.889314489 & 0.352870813 & $313,813.1273$ \\
I5 & 0.099214689 & 0.876280892 & $86,939.93587$ & 0.829612997 & 0.295095694 & $244,815.2229$ \\
I6 & 0.278177193 & 0.807263412 & $224,562.2697$ & 1 & 0.180023923 & $180,023.9234$ \\
\hline Concessions & Palestinians' & $\begin{array}{l}\text { Palestinians' } \\
\text { perception }\end{array}$ & Palestinians' & Israelis' & Israelis' per- & Israelis' total \\
& costs & of Israelis' & & benefits & ception of & gain \\
& & benefits & & & $\begin{array}{l}\text { Palestinians' } \\
\text { costs }\end{array}$ & \\
\hline Palestinians & & & & & & \\
PI & 0.965 & 0.156155821 & $150,690.3672$ & 0.721782283 & 1 & \\
P2 & 0.9623 & 0.87420471 & $841,247.1928$ & 0.932319713 & 0.884111655 & $824,274.7243$ \\
P3 & 0.8425 & 0.79339212 & $668,432.8608$ & 1 & 0.178727345 & $178,727.3449$ \\
P4 & 1 & 0.901886371 & $901,886.3712$ & 0.91489811 & 0.699695727 & $640,150.2982$ \\
P5 & 0.7656 & 0.960263422 & $735,177.6761$ & 0.344525393 & 0.449530361 & $154,874.6245$ \\
P6 & 0.8673 & 0.960263422 & $832,836.4661$ & 0.656530461 & 0.445164704 & $292,264.1887$ \\
P7 & 0.9848 & 0.878446255 & $865,093.8721$ & 0.668989547 & 0.547162323 & $366,045.8747$ \\
P8 & 0.9213 & 0.963277151 & $887,467.2396$ & 0.659275684 & 0.187590951 & $123,674.1526$ \\
P9 & 0.6498 & 0.130371693 & 84715.52629 & 0.5094499 & 0.273316576 & $139,241.1024$ \\
P10 & 0.8223 & 1 & 822300 & 0.967374089 & 0.625082683 & $604,688.7911$ \\
\hline & & & & & & \\
\hline
\end{tabular}

\section{Matched concessions}

\begin{tabular}{|c|c|c|c|}
\hline Israeli actions & Gain & Palestinian actions & Gain \\
\hline $\begin{array}{l}\text { 11. Right to choose to return } \\
\text { to their original home }\end{array}$ & 0 & $\begin{array}{l}\text { P9. Jewish refugees shall be } \\
\text { compensated }\end{array}$ & 8.595 \\
\hline $\begin{array}{l}\text { 13. Endorsement of the } \\
\text { international community }\end{array}$ & 1.965 & $\begin{array}{l}\text { P3. Resolution of the Pales- } \\
\text { tinian refugee issue will } \\
\text { settle all claims, collective } \\
\text { and individual, of the } \\
\text { Palestinian refugees }\end{array}$ & 0 \\
\hline $\begin{array}{l}\text { 15. International commission } \\
\text { to develop opportunities } \\
\text { for the refugees }\end{array}$ & 8.302 & $\begin{array}{l}\text { P1. Recognition of Israel as } \\
\text { the Nation State of the } \\
\text { Jewish people }\end{array}$ & 1.625 \\
\hline Total & 10.27 & & 10.22 \\
\hline
\end{tabular}

\section{Principles to solve the Palestinian refugee problem}

- The Palestinian refugees can choose to resettle in the State of Palestine, other host countries, or third party countries; those Palestinians who were originally displaced according to UNRWA's registry from the area inside the Green Line and their spouse will be permitted to return to the State of Israel within 5 years. Palestin- 
Table 29 Israeli, Palestinian gain ratios for Principle 7

\begin{tabular}{|c|c|c|c|c|c|c|c|c|c|c|c|c|c|}
\hline \multirow{2}{*}{$\begin{array}{l}\text { Israelis' } \\
\text { ratios }\end{array}$} & \multicolumn{13}{|c|}{ Palestinian's Concessions } \\
\hline & P1 & P2 & \multicolumn{2}{|l|}{ P3 } & P4 & \multicolumn{2}{|l|}{ P5 } & P6 & P7 & \multicolumn{2}{|c|}{ P8 } & P9 & P10 \\
\hline \multicolumn{14}{|c|}{ Israelis' concessions } \\
\hline 11 & 0 & 0 & \multicolumn{2}{|l|}{0} & 0 & \multicolumn{2}{|l|}{0} & 0 & 0 & \multicolumn{2}{|l|}{0} & 0 & 0 \\
\hline 12 & 4.168024 & 4.75988 & \multicolumn{2}{|c|}{1.032084} & 3.69663 & \multicolumn{2}{|l|}{0} & 1.687717 & 2.113779 & 90 & & 0 & 3.491853 \\
\hline 13 & 7.93604 & 9.06295 & 1.96 & 118 & 7.038491 & 1.70 & 856 & 3.213462 & 4.024697 & & .359805 & 1.530964 & 6.64859 \\
\hline 14 & 0 & 0 & 0 & & 0 & 0 & & 0 & 0 & 0 & & 0 & 0 \\
\hline 15 & 8.30208 & 9.480968 & 2.05 & 757 & 7.363133 & 1.78 & 398 & 3.361679 & 4.210331 & & .422524 & 1.601578 & 6.955248 \\
\hline 16 & 3.214174 & 3.670584 & 0 & & 2.850658 & 0 & & 1.301484 & 1.630042 & 120 & & 0 & 2.692744 \\
\hline Palestiniar & n's ratios & Palest & inian & con & cessions & & & & & & & & \\
\hline & & P1 & & $\mathrm{P} 2$ & P3 & & P4 & P5 & P6 & P7 & P8 & P9 & P10 \\
\hline Israelis'con & cessions & & & & & & & & & & & & \\
\hline 11 & & 4.8322 & & 0 & 1.0893 & & 0 & 0 & 0 & 0 & 0 & 8.595512 & 0 \\
\hline 12 & & 1.2477 & & 0 & 0 & & 0 & 0 & 0 & 0 & 0 & 2.219432 & 0 \\
\hline 13 & & 0 & & 0 & 0 & & 0 & 0 & 0 & 0 & 0 & 1.288043 & 0 \\
\hline 14 & & 2.0825 & & 0 & 0 & & 0 & 0 & 0 & 0 & 0 & 3.704317 & 0 \\
\hline 15 & & 1.6246 & & 0 & 0 & & 0 & 0 & 0 & 0 & 0 & 2.889851 & 0 \\
\hline 16 & & 1.1946 & & 0 & 0 & & 0 & 0 & 0 & 0 & 0 & 2.12504 & 0 \\
\hline Trade-off & Actic & $\mathrm{Ga}$ & & & Total & & & & & & & & \\
\hline Israeli & $\|$ & 0 & & & 10.2672 & & & & & & & & \\
\hline Palestinian & P9 & 8.5 & 9551 & & 10.22014 & & & & & & & & \\
\hline Israeli & 13 & 1.9 & 6511 & & & & & & & & & & \\
\hline Palestinian & P3 & 0 & & & & & & & & & & & \\
\hline Israeli & 15 & 8.3 & 0208 & & & & & & & & & & \\
\hline Palestinian & $\mathrm{Pl}$ & 1.6 & 2462 & & & & & & & & & & \\
\hline
\end{tabular}

ian refugees will be eligible for citizenship of the state they choose to resettle in or return to.

- All refugees have the right to compensation for their suffering and loss of property. An agreed upon international commission will handle all claims and implementation.

While the participants spent considerable time in developing the principles noted above to solve the Palestinian refugee problem, it became clear that these principles were actually guidelines to approach that problem and did not represent a totally implementable program. Still ahead will be a series of meetings to address the following issues which, when resolved, would hopefully yield the details of a workable program. These issues would be addressed in the following order:

1. How can we satisfy the Palestinian narrative about the importance of the right of return? We have already completed some aspects of this question in our last meeting.

2. How do we get information from the refugees themselves about what their needs and preferences are? And how do we get in touch with refugees in camps and who would they have confidence in talking to? 
3. How and where to resettle the refugees currently in camps and how can they be appropriately housed and given employment opportunities?

4. How can we compensate Palestinian refugees for the losses they have incurred, including who will be compensated, how much will they receive and where will the resources come from?

When this work is completed, the parties will have in hand a proposal for an approach, which is fair to both sides.

Principle 8 Limited Arms of the Palestinian state and international guarantees from the international community against aggression from other parties (see Tables 30, 31 and 32).

Table 30 Israeli benefits, costs, perceived benefits and perceived costs for Principle 8

\begin{tabular}{|c|c|c|c|c|c|}
\hline Israeli benefits from Palestinian concessions & \multicolumn{2}{|c|}{ Priorities } & P1 & P2 & P3 \\
\hline Reduction in threat from conventional military risk from Palestinians & \multicolumn{2}{|c|}{0.3278} & 1 & 0.975 & 0.862 \\
\hline No other country can support/aid Palestinians with military & \multicolumn{2}{|c|}{0.1883} & 0.563 & 0.525 & 1 \\
\hline Sense of security & \multicolumn{2}{|c|}{0.1726} & 0.975 & 1 & 0.862 \\
\hline \multirow[t]{2}{*}{ Using Palestinian airspace for military training } & \multicolumn{2}{|c|}{0.3113} & 0.938 & 0.033 & 0.07 \\
\hline & & & 0.8939 & 0.6012 & 0.6417 \\
\hline Israeli costs from Israeli concessions & \multicolumn{2}{|c|}{ Priorities } & 11 & 12 & 13 \\
\hline Threat & \multicolumn{2}{|c|}{0.4448} & 1 & 0.01 & 0.725 \\
\hline Loss of control & \multicolumn{2}{|c|}{0.4757} & 0.888 & 0.375 & 0.825 \\
\hline \multirow[t]{2}{*}{ Redeployment and restructuring how to 'deal' with the new status } & \multicolumn{2}{|c|}{0.0795} & \multirow{2}{*}{$\begin{array}{l}0.813 \\
0.9316 \\
\end{array}$} & 0 & 0 \\
\hline & & & & 0.1828 & 0.715 \\
\hline \multicolumn{2}{|l|}{ Israeli perception of Palestinian benefits from Israeli concessions } & Priorities & 11 & 12 & 13 \\
\hline \multicolumn{2}{|l|}{$\begin{array}{l}\text { Allocation of resources for economic development rather than military } \\
\text { expenditures }\end{array}$} & 0.5978 & 0.195 & 0.01 & 0.663 \\
\hline \multicolumn{2}{|l|}{ Declare and ensure the neutrality of the State of Palestine } & 0.1127 & 0.725 & 0.925 & 0.888 \\
\hline \multirow{2}{*}{\multicolumn{2}{|c|}{$\begin{array}{l}\text { Ensure the security of the State of Palestine through international guaran- } \\
\text { tees }\end{array}$}} & 0.2895 & 0.318 & 0.725 & 0.862 \\
\hline & & & 0.2902 & 0.3201 & 0.7458 \\
\hline \multicolumn{2}{|l|}{ Israeli perception of Palestinian costs from Palestinian concessions } & Priorities & P1 & P2 & P3 \\
\hline \multicolumn{2}{|l|}{ Risk associated with limited national defense } & 0.11 & 0.725 & 0.563 & 0.1 \\
\hline \multicolumn{2}{|l|}{ Political cost associated with the limitations of arms } & 0.2364 & 0.725 & 0.5 & 0.5 \\
\hline \multicolumn{2}{|l|}{$\begin{array}{l}\text { Financial burden incurred by the international community and to be shared } \\
\text { by the State of Palestine }\end{array}$} & 0.1688 & 0.033 & 0.502 & 0.313 \\
\hline \multirow{2}{*}{\multicolumn{2}{|c|}{ National pride undermined by limited arms policy }} & 0.4849 & 0.75 & 0.1 & 0.725 \\
\hline & & & 0.6203 & 0.3133 & 0.5335 \\
\hline
\end{tabular}

\section{Palestinian actions}

P1. List of forbidden weapons
(a) Strategic Weapons
(b) Tanks
(c) Missiles/Rocket
(d) Aircraft

P2. Monitoring

(a) Private groups

P3. Multinational monitoring (Principle 9) 
Table 31 Palestinian benefits, costs, perceived benefits and perceived costs for Principle 8

\begin{tabular}{|c|c|c|c|c|c|c|}
\hline Palestinian benefits from Israeli concessions & & & Prioriti & ies 11 & 12 & 13 \\
\hline $\begin{array}{l}\text { Allocation of resources for economic development rather than milite } \\
\text { ditures }\end{array}$ & y expen & & 0.2176 & 0.9 & 0.9 & 0.9 \\
\hline Declare and ensure the neutrality of the State of Palestine & & & 0.0503 & 1 & 1 & 0.9 \\
\hline Ensure the security of the State of Palestine through international gu & rantees & & 0.7322 & 1 & 1 & 0.9 \\
\hline & & & & 0.97 & 820.978 & $882 \quad 0.9$ \\
\hline Palestinian costs from Palestinian concessions & & Prio & orities & P1 & P2 & P3 \\
\hline Risk associated with limited national defense & & 0.66 & & 0.9 & 0.5 & 0.5 \\
\hline Political cost associated with the limitations of arms & & 0.21 & & 0.75 & 0.75 & 0.75 \\
\hline $\begin{array}{l}\text { Financial burden incurred by the international community and to be } \\
\text { by the State of Palestine }\end{array}$ & shared & 0.03 & & 0.25 & 0.25 & 0.25 \\
\hline National pride undermined by limited arms policy & & 0.07 & & 0.75 & 0.75 & 0.75 \\
\hline & & & & 0.8312 & 0.5645 & 0.5645 \\
\hline Palestinian perception of Israeli benefits from Palestinian conce & sions & & iorities & P1 & P2 & P3 \\
\hline Reduction in threat from conventional military risk from Palestinians & & & 2389 & 0.75 & 0.75 & 0.9 \\
\hline No other country can support/aid Palestinians with military & & & 478 & 0 & 0 & 0 \\
\hline $\begin{array}{l}\text { Social psyche: without the threat of military presence the social psyc } \\
\text { be relieved }\end{array}$ & e will & & 082 & 1 & 0.75 & 0.9 \\
\hline Using Palestinian airspace for military training & & & 222 & 0 & 0 & 0 \\
\hline Allows for finalization of the conflict & & & 828 & 0.9 & 0.75 & 0.9 \\
\hline & & & & 0.8119 & 0.6975 & 0.837 \\
\hline Palestinian perception of Israeli costs from Israeli concessions & Priorit & ties & 11 & 12 & & 13 \\
\hline Threat & 0.0377 & & 0.25 & & .01 & 0.01 \\
\hline Loss of control & 0.0998 & & 0.01 & & .01 & 0.01 \\
\hline Restructuring how to 'deal' with the new status & 0.5986 & & 0.1 & & .01 & 0.1 \\
\hline Political & 0.2639 & & 0.5 & 0 . & .5 & 0.25 \\
\hline & & & 0.20 & 023 & 1393 & 0.1272 \\
\hline
\end{tabular}

Israeli actions

1. Israeli commitment not to violate the Palestinian sovereignty by invading air space

2. Israel should abide by the international commitment to support principle 8

3. Israeli commitment not to violate the Palestinian sovereignty by invading borders

\section{Israeli perspective}

Benefits

1. Reduction in threat from conventional military risk from Palestinians.

2. No other country can support/aid Palestinians with military assistance.

3. Social psyche: without the threat of military presence the social psyche will be relieved (sense of security).

4. Using Palestinian airspace for military training.

5. Allows for finalization of the conflict.

Costs

1. Lack of control.

2. Threat.

3. Political.

4. Restructuring of how to 'deal' with the new status. 
Table 32 Israeli, Palestinian benefits and costs, perceived benefits and costs, and gain ratios for Principle 8

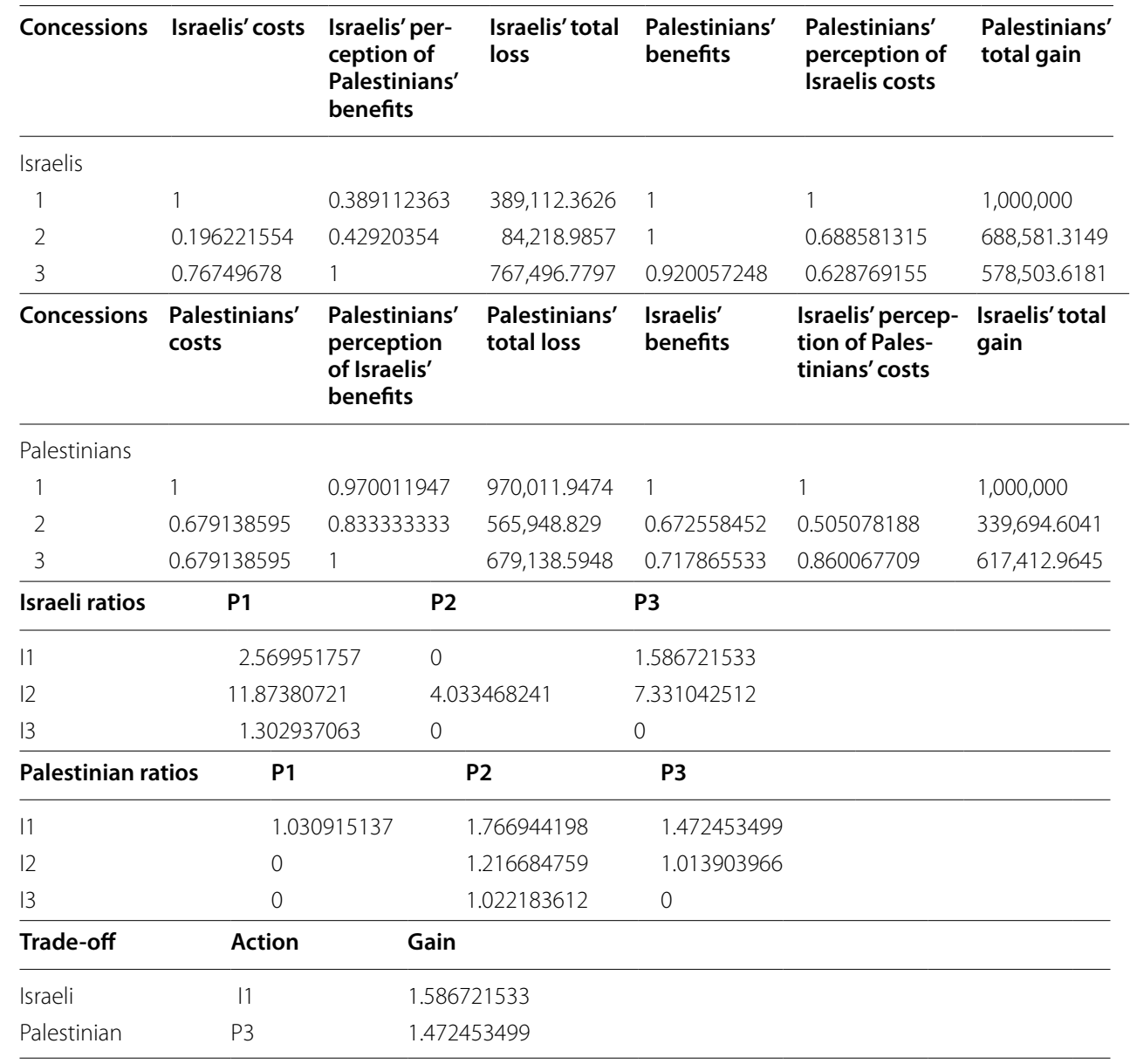

\section{Palestinian actions}

1. List of forbidden weapons.
a. Strategic weapons
b. Tanks.
c. Missiles/rocket.
d. Aircraft.

2. Monitoring by private groups.

3. Multinational monitoring (Principle 9).

\section{Palestinian perspective}

Benefits

1. Allocation of resources for economic development rather than military expenditures.

2. Declare and ensure the neutrality of the State of Palestine.

3. Ensure the security of the State of Palestine through international guarantees.

Costs

1. Threat.

2. Loss of control.

3. Redeployment and restructuring how to 'deal' with the new status. 


\section{Israeli actions}

1. Israeli commitment not to violate the Palestinian sovereignty by invading air space.

2. Israel should abide by the international commitment to support principle 8 .

3. Israeli commitment not to violate the Palestinian sovereignty by invading borders.

As a result of these matched concessions the actions to be required of each party will be as follows:

Israeli actions

- Israeli commitment not to violate the borders of the State of Palestine.

Palestinian actions

- Multi-national oversight-Principle 9.

Principle 9 Agreed upon international monitoring mechanism and agreed upon binding international arbitration mechanisms.

What is needed for the implementation of this principle is:

- Monitor and verify the implementation of the agreement.

- Time table for the implementation of the agreement.

- International arbitration mechanism to deal with any problems arising during implementation of agreements based on differences in interpretations.

\section{Conclusions and recommendations}

The outcomes noted previously represent a first step at producing a solution to the controversy, which can be used as a basis for further negotiation. With the exception of the refugee problem, it postulates what could be considered as a first draft for a proposal that would end hostilities. AHP has provided a solution which has drained much of the emotionality as it is possible in such circumstances. It has structured the problem much more efficiently than traditional face to face negotiations have been able to provide. At the same time, it has utilized a more refined measurement technique that makes it possible to compare the benefits and costs which each side sees as the result of the judgments they have made. When the total implementation of the refugee issue is completed, which may take another year, we will have produced, through AHP, an implementable proposal to begin a new era in the Middle East.

Over the last six decades, a veritable plethora of negotiators, presidents, foreign ministers, organizations like the United Nations, groups of allied countries, etc. have attempted to create peace in Israel and Palestine. However, no matter how worthy their intentions were, they have all failed. The basic premise of these negotiations has been that the way to a solution required an outside party to convince the principals to gather in the same room and begin negotiating. The outside parties then left the negotiators to attack one or more of the issues, together or separately, and find an acceptable outcome. While some progress was made using this approach, it was never an outcome which came even close to providing the necessary solution. 
So what is it we have produced that will move the process ahead to a point beyond what had been achieved to date? The AHP solution will eventually provide a proposal, with many of the details in place. It will suggest exactly where the borders should be for each country. It will drive away most of the emotionality from the discussions. It will identify which settlements will remain in Israeli possession and which will need, to either be closed or the communities remain in place, but under Palestinian sovereignty. It will suggest exactly how much land now owned by the Palestinians, but in the future will be occupied by the Israelis, needs to be counterbalanced by giving Israeli land to the Palestinians. It will evaluate the land offered for such land swaps in a mode that will be satisfactory to the Palestinian side. It will identify East Jerusalem as the capital of the Palestinian State, but will maintain the status quo of the holy places in Jerusalem.

It will permit the Palestinians to acknowledge the existence of Israel as a Jewish State while guaranteeing the rights of its minority citizens. It will guarantee that Israel will respect the integrity of the West Bank and Gaza by allowing free and safe passage between the two areas. It will guarantee the evacuation of Israeli settlers from the Palestinian territories that are not included in the land swaps. It will guarantee that the Palestinians will be in full control of the Palestinian State border and its outlets. It will permit the deployment of a temporary agreed upon multinational military monitoring system in the Jordan Valley. It will limit the arms permitted to the Palestinian state and provide international guarantees against aggression from other parties. It will identify the process by which both communities will have access to the holy places.

Eventually it will outline a specific outcome whereby some Palestinian refugees have the option to return to live in Israel if they wish. It will also address the question of what compensation should be paid to which refugees and how they might be resettled in other countries or territories. This portion of the work remains to be completed.

One may ask whether this constitutes a complete solution to the problem at hand. The answer is an obvious no. Many details remain to be settled. Some disagreement among the official negotiators will inevitably require modification of parts of the outcomes noted above. There also is the question of whether a different set of participants expressing different judgments may reach different conclusions. While that may be true, the credibility of the current participants suggests that the outcomes might be quite similar. But even if that is not the case, we will produce, through AHP, an outcome that provides an implementable alternative solution. No matter how the outcomes are produced, what the actual negotiators will have in hand is an implementable or partially implementable proposal that has been provided by knowledgeable people on both sides and supported by a far more scientific approach, using quantitative and computer technology, than has ever been attempted before. It is far more likely that a group of negotiators reviewing a detailed, specific and implementable solution will be able to modify it towards a final agreement than if they were starting from scratch in trying to develop a solution without structural foundation and judgments which are unique to AHP. After 60 years of trying the parties might be well advised to think outside of the box and look at the picture with a different focus.

One may skeptically argue that even with such a cool-headed rational agreement between the two sides, negatives have so dominated the scene, since the beginning, that what one has done on paper will encounter such resistance that people would give up 
and the conflict would continue. Whatever solution is provided, it will inevitably require a vote by the populations of both sides. Even if the Gaza population would vote negative, on the recommendation of its Hamas constituency, the proposal might be approved by an overriding positive vote of its West Bank constituency. Similarly, certain groups within the Israeli side will likely vote negative. However, using democratic principles, the majority should prevail, even if the vote is close. Just how strong the residents of Israel and Palestine feel about the advantages of peace versus the current conflict will be recorded in the vote. If the vote is close, one or both sides will have an implementation problem that would certainly be difficult. If the popular vote is positive on one side and negative on the other, the negotiators will have to go back to work. But, at least, the populations will have had a chance to express their democratic position. Getting to that stage of the negotiations would be a step forward that might suggest sufficient momentum to adjust the proposal enough to engender majority support.

Thinking outside of the box is always painful and breeds uncertainty. An AHP-derived solution will certainly be a novel way of ending the controversy, but when all else has failed, summoning the courage to consider unique approaches may be what is called for in these dire circumstances.

Authors' contributions

TLS, LGV and HJZ contributed equally to this work. All authors read and approved the final manuscript.

Compliance with ethical guidelines

Competing interests

The authors declare that they have no competing interests.

Received: 6 August 2015 Accepted: 7 August 2015

Published online: 18 September 2015

References

Saaty, T. (2005). Theory and Applications of the Analytic Network Process (p. 15213). Pittsburgh: RWS Publications, 4922

Ellsworth Avenue.

Skoll, J. (2013). One 60 minutes TV Program, Interviewed by Charlie Rose.

\section{Submit your manuscript to a SpringerOpen ${ }^{\circ}$} journal and benefit from:

- Convenient online submission

- Rigorous peer review

- Immediate publication on acceptance

- Open access: articles freely available online

- High visibility within the field

- Retaining the copyright to your article 